
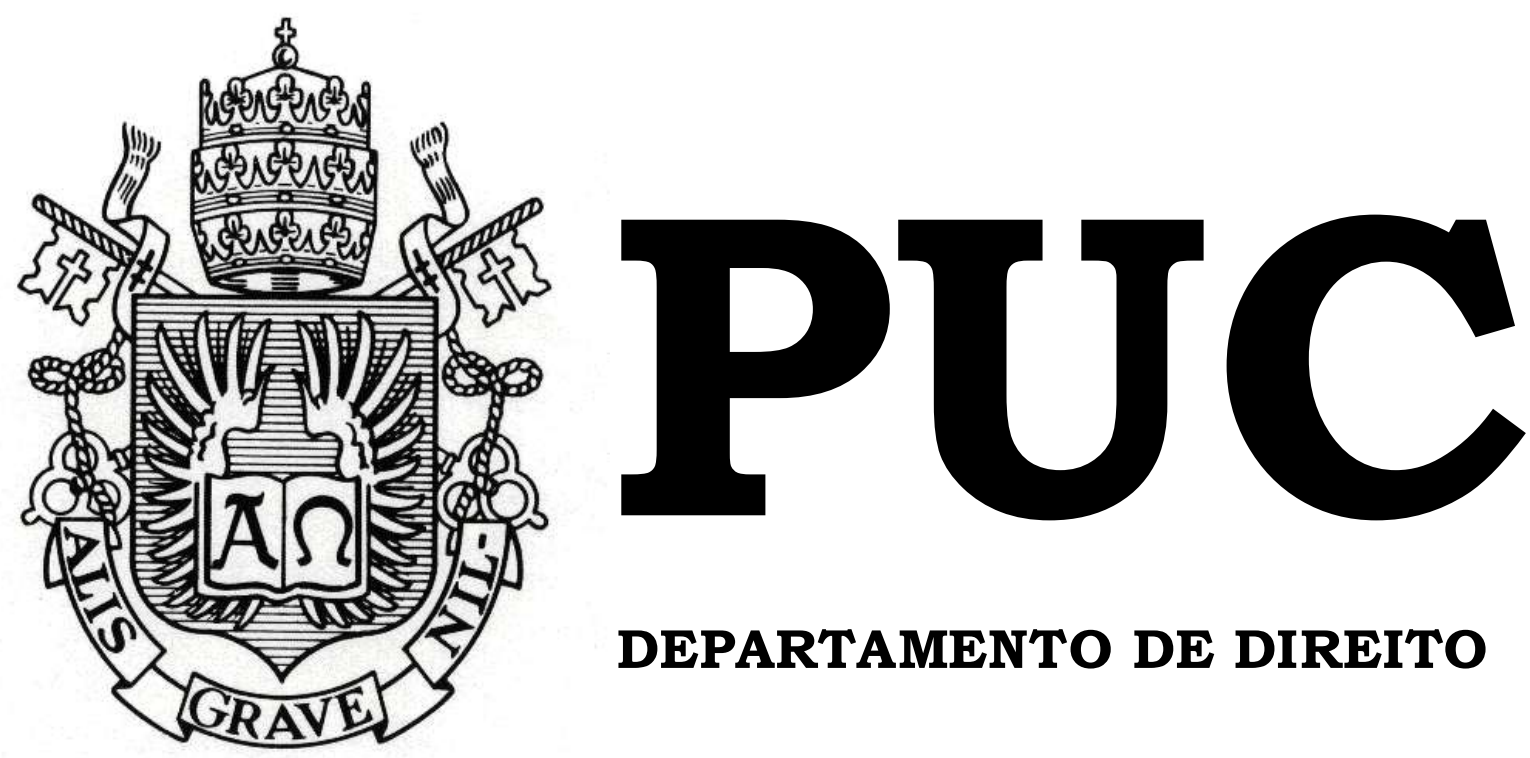

DEPARTAMENTO DE DIREITO

\title{
ADVOCACIA PRO BONO UM ESTUDO ACERCA DE SUA IMPLEMENTAÇÃO NO BRASIL
}

Por

HANNAH DIAS RABE

ORIENTADORA: DENISE MULLER DOS REIS PUPO

2016.2

PONTIFÍCIA UNIVERSIDADE CATÓLICA DO RIO DE JANEIRO

RUA MARQUÊS DE SÃO VICENTE, 225 - CEP 22451-900

RIO DE JANEIRO - BRASIL 


\title{
ADVOCACIA PRO BONO UM ESTUDO ACERCA DE SUA IMPLEMENTAÇÃO NO BRASIL
}

por

\section{HANNAH DIAS RABE}

\author{
Monografia apresentada ao \\ Departamento de Direito da \\ Pontificia Universidade Católica do \\ Rio de Janeiro (PUC-Rio) para a \\ obtenção do Título de Bacharel em \\ Direito.
}

Orientadora: Denise Muller dos Reis Pupo 


\section{RESUMO}

O Brasil é um país de extrema desigualdade social. Diante disso, a CRFB88 estabelece como dever do Estado prestar assistência jurídica gratuita aos hipossuficientes a fim de assegurar a inafastabilidade da jurisdição. Contudo, os Governos não conseguem atender à demanda, o que levou a sociedade civil a se organizar para suprir a falta estatal. Nesse sentido, os advogados, conscientes de sua função social, se viram responsáveis pela ampliação do acesso à justiça surgindo a advocacia pro bono, consistente na prestação de assistência jurídica gratuita e voluntária aos juridicamente pobres. Ocorre que esse instituto, por ser uma atividade organizada, sistemática e regular, necessita de uma regulamentação rígida, a fim de coibir eventuais abusos. Apesar das divergências doutrinárias e dos entraves políticos, a advocacia pro bono finalmente foi permitida e regulamentada pelo vigente Código de Ética e Disciplina da OAB, ampliando o acesso à justiça ao se tornar mais uma via de materialização de direitos da população brasileira.

Palavras-Chave: Desigualdade social; assistência jurídica gratuita; advocacia pro bono; responsabilidade social da advocacia; código de ética e disciplina da $\mathrm{OAB}$. 


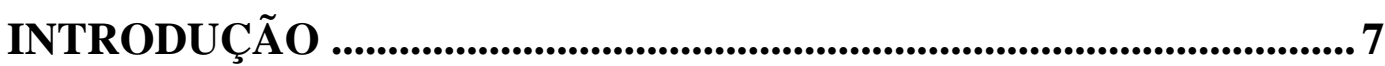

CAPÍTULO 1 - ACESSO À JUSTIÇA E A RESPONSABILIDADE SOCIAL DA ADVOCACIA NO CENÁRIO BRASILEIRO ....................9

1.1. O acesso à justiça: entre a garantia constitucional e a insuficiência estatal 9

1.1.1. A CRFB/88 e o acesso à justiça em um país de extrema desigualdade social. 9

1.1.2. Por que o pleno acesso à justiça é fundamental para a sociedade brasileira?

1.2. As dificuldades estatais em suprir as demandas jurisdicionais e suas

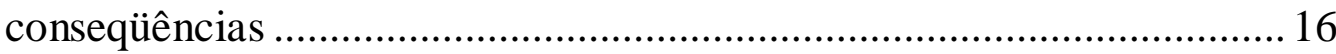

1.3. A responsabilidade social da advocacia ........................................... 20

1.3.1. Breve desenvolvimento da responsabilidade social no Brasil.......20

1.3.2. Responsabilidade social da advocacia como instrumento transformador da sociedade brasileira ..................................................... 22

CAPÍTULO 2 - ADVOCACIA PRO BONO..............................................2 27

2.1. ADVOCACIA PRO BONO: AFINAL DO QUE SE TRATA?.......27

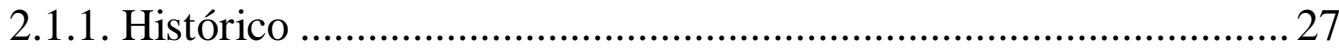

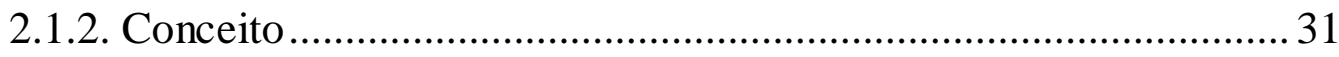

2.1.3. Regulamentação inicial e o papel da $\mathrm{OAB}$...................................... 33

2.1.3.1 Posicionamentos das Seccionais da Ordem dos Advogados do Brasil dos Estados do Rio de Janeiro, Alagoas e Minas Gerais antes do

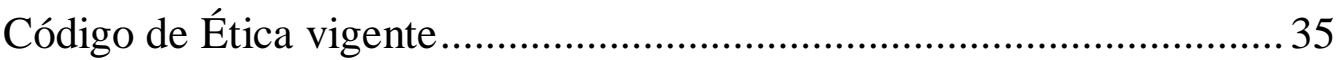

2.1.3.2. A importância da seccional da OAB-SP no debate da regulamentação da advocacia pro bono em âmbito nacional..................... 38

2.2. Advocacia pro bono x Advocacia pública gratuita ............................. 49

2.2.1. Qual a diferença entre a advocacia pública gratuita e a advocacia pro bono? 49 
2.2.1.1. Advogados dativos $\mathrm{x}$ advogados solidários

52

2.2.1.2. O papel da Defensoria Pública no contexto da assistência jurídica gratuita 56

2.2.2. Advocacia pro bono eadvocacia pública gratuita: se excluem ou se complementam? 59

2.3. Advocacia pro bono x Assistencialismo 62

CAPÍTULO 3 - ADVOCACIA PRO BONO: FUNDAMENTO LEGAL E POSIÇÕES DOUTRINÁRIAS ................................................................... 66

3.1. Leis e disposições normativas atuais ............................................. 66

3.2. Discussão doutrinária acerca da advocacia pro bono ...................... 69

3.2.1. Captação de clientela e promoção pessoal .................................. 70

3.2.2. Concorrência desleal.............................................................. 73

3.2.3. Substituição do Estado na prestação de assistência jurídica gratuita

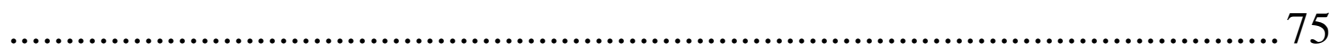

3.2.4. Inconstitucionalidade na proibição da advocacia pro bono .......... 76

3.2.5. Importância da advocacia pro bono na transformação da realidade

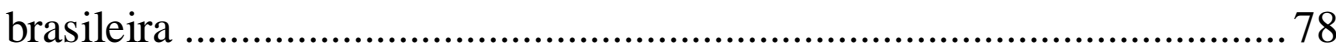

3.2.5.1. Benefício para a sociedade ................................................ 78

3.2.5.2. Benefício para o advogado solidário ...................................... 82

3.3. Próximos passos e desafios a serem superados ............................. 84

CONCLUSÃO .................................................................................................. 90

REFERÊNCIAS BIBLIOGRÁFICAS ...................................................91 


\section{LISTA DE ABREVIATURAS}

IDH - Índice de desenvolvimento humano

INAJ - Índice Nacional de Acesso à Justiça

OAB - Ordem dos Advogados do Brasil

OAB-SP - Ordem dos Advogados do Brasil do Estado de São Paulo

OAB-RJ - Ordem dos Advogados do Brasil do Estado do Rio de Janeiro

TED - Tribunal de Ética e Disciplina da Ordem dos Advogados do Brasil

TED-SP - Tribunal de Ética e Disciplina da Seccional de São Paulo da

Ordem dos Advogados do Brasil

IPB - Instituto Pro Bono

OSCIP - Organização da Sociedade Civil de Interesse Público

ONG - Organização Não Governamental

CED - Código de Ética e Disciplina da OAB

CRFB/88 - Constituição da República Federativa do Brasil de 1988 
"A vocação do advogado revelase, por inteiro, ao graciosamente dedicar-se com afinco à defesa de direito de pessoa carente".

Miguel Reale Júnior 


\section{INTRODUÇÃO}

O presente trabalho tem como escopo principal realizar uma análise acerca do desenvolvimento e da regulamentação da advocacia pro bono no Estado brasileiro, ressaltando sua importância na ampliação do acesso à justiça.

Isso porque a sociedade brasileira é uma das mais desiguais e violentas do mundo, onde os direitos fundamentais, principalmente da população carente, são diariamente violados sem que haja a devida tutela por parte do Poder Judiciário.

Dentre os direitos fundamentais, encontra-se o pleno acesso à justiça, positivado no artigo $5^{\circ}$, inciso $\mathrm{XXXV}$, da $\mathrm{CRFB} / 88$, o qual igualmente não é assegurado aos seus titulares, tendo em vista as limitações do Estado.

Entretanto, a ausência desse direito agrava o quadro social brasileiro, tendo em vista que gera violência através da "justiça com as próprias mãos", bem como faz com que os excluídos da sociedade permaneçam sem dignidade e cidadania.

Conforme se demonstrará ao longo da monografia, a advocacia pro bono, também conhecida por advocacia solidária, é oriunda da responsabilidade social da advocacia, por meio da qual os profissionais do Direito, percebendo a insuficiência estatal, cumprem sua função social à medida que utilizam suas habilidades funcionais para estender o acesso à justiça àqueles que não possuem devido a questões financeiras.

Dessa forma, entende-se que a advocacia pro bono, ao lado de diversas outras modalidades, constitui um mecanismo do setor privado de ampliação das portas da justiça capaz de minimizar as mazelas da sociedade, sendo certo que possui caráter suplementar à obrigação estatal de prover assistência jurídica gratuita aos hipossuficientes.

Todavia, apesar de sua importância, a implementação do referido instituto sofreu rigorosos entraves, de modo que tal atividade somente foi efetivamente regulamentada em 2015, através da Resolução nº 02/2015 do 
Conselho Federal da Ordem dos Advogados do Brasil, que aprovou onovo Código de Ética e Disciplina da $\mathrm{OAB}$, não obstante seja praticada desde o Império.

A fim de uma melhor explanação sobre o tema, a monografia foi dividida em três partes.

A primeira consiste na análise da sociedade brasileira contemporânea em relação ao acesso à justiça, considerando, de um lado, a garantia constitucional desse direito e sua importância e, de outro, a incapacidade dos Governos de proverem a assistência jurídica integral e gratuita aos que dela necessitam e suas consequências. Ainda, observa-se como a responsabilidade social da advocacia pode amenizar o quadro social brasileiro ao abrir as portas do Judiciário para os excluídos.

O segundo capítulo destina-se a conhecer a advocacia pro bono em si, delimitando seu conceito, apresentando a história de seu desenvolvimento e de sua regulamentação, principalmente no tocante aos posicionamentos das seccionais da $\mathrm{OAB}$, bem como diferenciar essa prática das demais modalidades similares.

No último capítulo pretende-se analisar o embasamento legal que legitima a prática pro bono, bem como se busca realizar uma visão crítica acerca dos argumentos contrários e à favor da implementação da advocacia pro bono no Brasil como uma atividade organizada, regular e regulamentada. Ao final, elucidam-se, ainda, os desafios a serem superados após a efetiva regulamentação.

Por fim, importante ressaltar que o material de pesquisa referente ao tema em questão revela-se bastante escasso para consulta, não havendo livros sobre o assunto. Dessa forma, a metodologia utilizada para realizar essa monografia baseou-se, principalmente, em artigos escritos por diversos juristas e estudiosos do tema, bem como em entrevistas realizada pela autora do trabalho. 


\section{CAPÍTULO 1 - ACESSO À JUSTIÇA E A RESPONSABILIDADE SOCIAL DA ADVOCACIA NO CENÁRIO BRASILEIRO}

A fim de uma melhor compreensão acerca da implementação da advocacia pro bono no Brasil, mister se faz a análise do atual contexto político-social, no qual a sociedade está inserida.

Isso porque, como se melhor analisará no decorrer do trabalho, a atividade pro bono surgiu da necessidade de ampliação do acesso à justiça à população mais carente, a qual, por encontrar-se a margem da tutela jurisdicional, carece de meios eficazes para materializar seus direitos.

\subsection{O acesso à justiça: entre a garantia constitucional e a insuficiência estatal}

\subsubsection{A CRFB/88 e o acesso à justiça em um país de extrema desigualdade social}

A Constituição da República de 1988 é considerada marco inicial da redemocratização do Brasil após mais de vinte longos anos de um regime ditatorial e arbitrário, eis que responsável por instituir o Estado Democrático de Direito com a ampliação de garantias jamais vista até então.

Por essa razão, segundo preleciona Oscar Vilhena Vieira ${ }^{1}$, a Carta Magna baseia-se nos princípios do devido processo legal, da democracia e dos direitos humanos, bem como garante os direitos sociais, políticos, civis e econômicos como cláusula pétrea.

\footnotetext{
${ }^{1}$ VIEIRA, Oscar Vilhena. A desigualdade e a subversão do Estado de Direito. Revista
} Internacional de Direito e Cidadania, n. 1, junho/2008. Pp. 185-201. 
Entretanto, a América do Sul é uma região conhecida por ostentar alto grau de violência e desigualdade, sendo certo que o Brasil possui um dos maiores índices de desigualdade do continente, conforme corroboram Marta Lagos e Lucía Dammert. ${ }^{2}$

Assim, não obstante o Brasil seja a $9^{\text {a }}$ maior economia mundial ${ }^{3}$., dados do Relatório do Desenvolvimento Humano referente ao ano de $2015^{4}$, responsável por medir os índices de desenvolvimento humano (IDH) de cada país, demonstram que o Estado brasileiro ocupa a $75^{\text {a }}$ posição no ranking, ficando consideravelmente abaixo de seus vizinhos Argentina $\left(40^{\mathrm{a}}\right)$, Chile $\left(42^{\mathrm{a}}\right)$ e Uruguai $\left(52^{\mathrm{a}}\right)$

Cumpre ressaltar, por oportuno, que o IDH, com o objetivo de mensurar a efetiva qualidade de vida da população de determinado país, estabelece os seguintes critérios de análise: a expectativa de vida do indivíduo, a renda per capita, a escolaridade e a desigualdade de renda. ${ }^{5}$

Seguindo esse diapasão, conforme ressalta Guilhermo O'Donnel ${ }^{6}$, a extrema desigualdade encontrada na América Latina foi um dos fatores mais decisivos a impedir a consolidação, de forma efetiva, dos sistemas do Estado de Direito, tendo em vista a ausência do domínio da lei.

Conforme a análise de dados do Instituto de Pesquisa de Econômica Aplicada (Ipea) ${ }^{7}$, é possível observar que, no Brasil, 4,2\% da população encontra-se na linha de extrema pobreza e 13,29\% na linha de pobreza.

Imperioso ressaltar que, de acordo com Nádia Barros e Marcos Fuchs $^{8}$, a pobreza transcende à simples questão financeira, caracterizando-

\footnotetext{
${ }^{2}$ LAGOS, Marta e Lucía Dammert. La Seguridad Ciudadana: El problema principal de América Latina. Ltinobarómetro, 09 de maio de 2012, p. 3.

${ }^{3}$ EXAME. Brasil cai para a posição de $9^{a}$ economia do mundo. Disponível em: $<$ http://exame.abril.com.br/economia/pib-em-dolar-cai-25-e-brasil-cai-para-a-posicao-de-9aeconomia-do-mundo/>. Acesso em: 09/10/2016.

${ }^{4}$ JAHAN, Selim. Relatório do desenvolvimento humano 2015. Disponível em: <http://hdr.undp.org/sites/default/files/hdr15_overview_pt.pdf >. Acesso em: 09/10/2015.

${ }^{5}$ FUCHS, Marcos Roberto e Flávia Piovesan. Advocacia de interesse público e o Instituto Pro Bono. Revista Jurídica Consulex, ano XVII, n. 398, 15 de ago de 2013. Pp. 40-42.

${ }^{6}$ O'DONNEL, Guilhermo. Poliarquias e a (In)efetividade da Lei na América Latina. Novos Estudos, Cebrap, 51, 1998. Pp. 37-57.

${ }^{7}$ APLICADA, Instituto de Pesquisa Econômica. Proporção de extremamente pobres (P0) - Linha de Pobreza Baseada em Necessidades Calóricas e Proporção de pobres (PO) - Linha de Pobreza Baseada em Necessidades Calóricas. Disponível em: 〈http://www.ipeadata.gov.br/>. Acesso em: 22/10/2016.
} 
se, inclusive, mais pela falta de serviços fundamentais, denominada de entitlements.

Assim sendo, percebe-se que a exclusão social oriunda da pobreza é relativa, não depende apenas da falta de recursos financeiros para frequentar determinados lugares ou adquirir certos bens. Nesse diapasão, há pobreza quando alguém não consegue alcançar sua cidadania ou não possui saneamento básico em sua residência, por exemplo.

Ainda, salientam Marcos e Nádia que no que concerne à justiça, os obstáculos podem ter dois aspectos, sendo um econômico e outro cultural. O primeiro leva em consideração os significativos valores das custas processuais, enquanto o segundo considera os milhares de brasileiros que não possuem consciência de seus direitos, ficando a margem da administração da justiça.

Tais considerações se mostram atuais e ressaltam as dificuldades do país em promover o acesso à justiça da população. Isso porque, tradicional estudo de Mauro Cappelletti e Bryan Garth, realizado no final da década de $70^{9}$, já apontava as dificuldades do acesso à justiça pelo cidadão pobre nas sociedades contemporâneas, justamente devido ao alto valor das custas judiciais, à contratação e qualificação dos advogados, ao custo emocional e financeiro em razão da morosidade do processo, à aptidão ou inaptidão para reconhecer um direito e proporção ou defesa judicial e à falta de compreensão do sofisticado sistema judiciário, nos descompassos entre litigantes eventuais e litigantes habituais.

Assim sendo, em um país de condições tão precárias, onde o Estado não consegue assegurar sequer os direitos fundamentais mais elementares, tais como o direito à vida, educação e saúde, incontestável que o direito fundamental de acesso à justiça igualmente não consegue ser garantido.

${ }^{8}$ BARROS, Nádia e Marcos Roberto Fuchs. Por que os advogados não podem atender de graça? Disponível em: <http://reporterbrasil.org.br/2013/12/por-que-os-advogados-brasileiros-naopodem-atender-de-graca/>. Acesso em: 22/07/2016.

${ }^{9}$ CAPPELlETTI, Mauro e BRYANT, Garth. Acesso à Justiça. Porto Alegre: Sergio Antonio Fabris Editor, 1988. 
Corroborando tal afirmativa, Flávia Piovesan e Marcos Fuchs ${ }^{10}$ ressaltam que apenas $30 \%$ da população brasileira conseguem acessar o Poder Judiciário, a fim de obter uma tutela jurisdicional.

Contraditoriamente, o Brasil possui um alto grau de litigiosidade, tendo em vista a homérica quantidade de processo pendente de julgamento pelo Poder Judiciário.

Isso porque, se por um lado a CRFB/88 ampliou os direitos da população brasileira, por outro, deu visibilidade ao Judiciário como garantidor desses novos direitos aumentando a demanda da população diante da maior regulação da vida privada.

Assim, a judicialização das relações sociais é uma realidade no país assim compreendida, em estudo realizado por Luiz Werneck Vianna em $1999^{11}$, como a crescente invasão do direito na organização da vida social.

Diversas autoridades e estudiosos do tema ressaltaram a questão da falta de acesso à justiça, bem como evidenciaram o excesso de processos em trâmite no Judiciário, em seus discursos proferidos na audiência pública realizada em São Paulo pelo Ministério Público Federal, no ano de 2013, a fim de debater a regulamentação da advocacia pro bono, como se observa a seguir. ${ }^{12}$

Devido à latente litigiosidade encontrada na sociedade brasileira, o ministro Gilmar Mendes relatou ser possível afirmar que uma faceta do Estado Social brasileiro se dá através da judicialização.

Ocorre que, infelizmente, a maior parte da população permanece à margem da prestação jurisdicional, não possuindo meios de defender seus direitos perante o Judiciário, razão pela qual Miguel Reale Júnior afirmou no evento que temos "muitos processos e poucas partes".

\footnotetext{
${ }^{10}$ FUCHS, Marcos Roberto e Flávia Piovesan. Advocacia de interesse público e o Instituto Pro Bono. Revista Jurídica Consulex, ano XVII, n. 398, 15 de ago de 2013. P. 40-42.

${ }^{11}$ WERNECK VIANNA et al. A judicialização da política e das relaçõessociais no Brasil. Rio de Janeiro: Revan, 1999.

12 Audiência pública organizada pelo Ministério Público Federal para discutir o tema da advocacia pro bono, realizada em São Paulo no dia 22 de fevereiro de 2013, transcrita pelo repórter da revista Consultor Jurídico. CANÁRIO, Pedro. Advogados se voltam contra Resolução Pro Bono da OABSP. Disponível em <http://www.conjur.com.br/2013-fev-23/grandes-nomes-advocacia-voltamresolucao-pro-bono-oab-sp>. Acesso em: 10/10/2016.>. Acesso em: 10/10/2016.
} 
O secretário da Reforma do Judiciário, Flávio Crocce Caetano, informou dados do INAJ, os quais demonstram que já em 2013 havia mais de 90 milhões de processos tramitando no Poder Judiciário.

Todavia, o secretário corrobora a afirmação de Miguel Reale Junior, explicando que no universo do Poder Judiciário há a presença dos grandes litigantes, que são os governos e bancos. Em seu discurso, o secretário de Reforma do Judiciário afirmou ser o primeiro grupo responsável pela propositura de $51 \%$ das demandas judiciais, enquanto o segundo grupo responde por $38 \%$ das ações em trâmite.

Por todo o exposto no presente tópico, conclui-se que a população brasileira, apesar de o Brasil figurar como a $9^{\text {a }}$ maior economia mundial, possui um enorme déficit social tendo em vista a latente violência, miséria e desigualdade, o que caracteriza uma sociedade, em sua maioria, excluída e negligenciada pelo Estado, o que reflete diretamente no seu direito fundamental de acesso à justiça, limitando-o.

\subsubsection{Por que o pleno acesso à justiça é fundamental para a sociedade brasileira?}

Cumpre ressaltar, primeiramente, que conforme preleciona Flavia Piovesan ${ }^{13}$, o Estado Democrático de Direito é caracterizado pela existência do monopólio da função jurisdicional pelo Poder Judiciário.

Destarte, todo indivíduo que possui um direito violado, deve recorrer a esse Poder, tendo em vista que ele é o responsável por "dizer o direito".

Não por outra razão, Marcos Fuchs e Flávia Piovesan ${ }^{14}$ asseveram que o acesso à justiça é pressuposto para a materialização e proteção de todos os demais direitos, tais como o direito à vida, liberdade, igualdade, saúde, educação, bem como consiste em um importante instrumento para a

\footnotetext{
${ }^{13}$ CANÁRIO, Pedro. Advogados se voltam contra Resolução Pro Bono da OAB-SP. Disponível em $<$ http://www.conjur.com.br/2013-fev-23/grandes-nomes-advocacia-voltam-resolucao-pro-bonooab-sp>. Acesso em: 10/10/2016.>. Acesso em: 10/10/2016.

${ }^{14}$ FUCHS, Marcos Roberto e Flávia Piovesan. Advocacia de interesse público e o Instituto Pro Bono. Revista Jurídica Consulex, ano XVII, n. 398, 15 de ago de 2013. Pp. 40-42.
} 
distribuição de justiça, razão pela qual afirmam ser o acesso à justiça um direito humano em si mesmo.

Insta salientar, por oportuno, que, segundo os supramencionados autores, o direito de acesso à justiça possui três dimensões, quais sejam:

(i) o livre acesso ao Poder Judiciário, a fim de que a pretensão resistida do indivíduo obtenha uma tutela jurisdicional;

(ii) a independência judicial, caracterizada pela possibilidade de toda pessoa ser ouvida por um juiz competente, independente e imparcial dentro de um prazo razoável e tendo as garantias observadas ao longo do processo; (iii) a prestação jurisdicional efetiva, consistente nas medidas coercitivas impostas pelo Judiciário ao reconhecer a violação de um direito no caso concreto.

Dessa forma, entende-se que o direito ao acesso à justiça não se limita à simples propositura, perante o Judiciário, de demandas judiciais, eis que compreende, também, a análise minuciosa do caso por um juízo competente, em um prazo razoável e com a adoção de medidas efetivas para fazer cessar a violação do direito em questão.

Acrescenta-se, ainda, que uma faceta do direito de acesso à justiça traduz-se não em provocar o Poder Judiciário, mas sim apenas na orientação jurídica dada às pessoas acerca de seus direitos, a fim de uma maior conscientização.

Assim sendo, em um país onde os direitos mais fundamentais são recorrentemente violados, a ampliação do acesso à justiça se revela medida imperiosa, a fim de proteger todos os demais direitos.

Por essa razão, a Constituição da República ${ }^{15}$, em seu artigo $5^{\circ}$, inciso XXXV, assegurou a inafastabilidade da jurisdição, ao determinar que nenhuma lesão ou ameaça a direito será excluída da apreciação do judiciário, bem com não serão criados obstáculos ao acesso à Justiça.

15 PLANALTO. Constituição da República federativa do Brasil de 1988. Disponível em: <http://www.planalto.gov.br/ccivil_03/constituicao/constituicaocompilado.htm>. Acesso em: $13 / 06 / 2016$. 
Todavia, conforme ressalta Fernando Modé ${ }^{16}$, para que um indivíduo possa acionar o Poder Judiciário, a contratação de um advogado se faz medida imperiosa, tendo em vista que o referido profissional é o único que possui competência funcional e habilidade técnica para postular em juízo.

Ocorre que, em uma sociedade onde a miséria é latente, a assistência jurídica prestada por advogados privados revela-se um verdadeiro privilégio, eis que acessível apenas por uma pequena parcela da população, a qual possui recursos financeiros para custear os honorários devidos.

Assim sendo, o supracitado autor salienta que, diante da dificuldade de acesso à justiça acima apresentada, pode-se falar em "ônus de ação", em contraposição ao "direito de ação", previsto no artigo $5^{\circ}$, inciso XXXV, da Constituição da República.

Atenta a isso e considerando a necessidade de se estender o acesso à justiça às classes menos abastadas, a Constituição da República ${ }^{17}$ determinou, em seu artigo $5^{\circ}$, inciso LXXIV, que é dever intransferível do Estado prover assistência jurídica integral e gratuita àqueles que comprovassem insuficiência de recursos.

Visando dar efetividade ao dispositivo supramencionado, a Carta Magna determinou, em seu artigo 134, a implementação das Defensorias Públicas em todos os Estados, visando a promoção dos direitos humanos e a defesa dos direitos individuais e coletivos dos hipossuficientes, de forma integral e gratuita.

Dessa forma, nascia para o Estado, principalmente através da Defensoria Pública, o dever intransferível e irrenunciável de prestar assistência jurídica gratuita àqueles que não podem arcar com os honorários sem o prejuízo de seu sustento ou do de sua família, equiparando-os à parcela da população mais abastada.

\footnotetext{
${ }^{16}$ MODÉ, Fernando Magalhães. A função social do advogado e a advocacia pro bono. Revista de Direito do Terceiro Setor - RDTS, ano 1, n. 1, jan/ jun. 2007. Disponível em: http://www.editoraforum.com.br/ef/wp-content/uploads/2016/08/funcao-social-doadvogado.pdf.>. Acesso em: 04/08/2016.

${ }^{17}$ PLANALTO. Constituição da República federativa do Brasil de 1988. Disponível em: <http://www.planalto.gov.br/ccivil_03/constituicao/constituicaocompilado.htm〉. Acesso em: 13/06/2016.
} 
Cumpre ressaltar, por oportuno, que a Lei 1.060/50 garante a gratuidade de justiça à população que não tem condições de arcar com os altos custos do Judiciário já desde os anos 50. Os seus termos foram ratificados e ampliados recentemente pelo novo Código de Processo Civil (Lei 13.105/2015), mas a mera garantia formal da gratuidade não garante o acesso à justiça pela população pobre mais próxima do Judiciário, que merece poder contar com meios alternativos de assistência jurídica gratuita na busca de concretização de direitos.

Por todo o exposto, em um cenário igual ao brasileiro, onde o acesso à justiça é escasso, a democratização desse direito se revela medida imperiosa à consolidação do Estado de Direito e da democracia, eis que somente através dele será possível a efetivação de todos os demais direitos, mitigando, enfim, a desigualdade e violência latentes.

\subsection{As dificuldades estatais em suprir as demandas jurisdicionais e suas consequências}

Conforme o anteriormente exposto, a Constituição da República trouxe um enorme progresso em relação à ampliação do acesso à justiça no Brasil, ao passo que determinou a obrigatoriedade do Poder Público em prestar assistência jurídica gratuita, bem como estipulou a criação das Defensorias Públicas, órgãos destinados a prestar o referido serviço em favor dos hipossuficientes, fazendo com que a classe menos abastada possa ter seus direitos defendidos perante o Estado.

Ocorre que, conforme se têm percebido ao longo dos últimos 28 anos, o Estado não consegue, por si só, prover assistência jurídica gratuita a todos os que dela necessitam e ainda dar conta de todas as suas demais atribuições, em decorrência de diversos fatores. É o que se demonstrará a seguir. 
Em primeiro lugar, cumpre salientar que a determinação constitucional que prevê a criação das Defensorias Públicas nos Estados levou décadas até ser integralmente cumprida em âmbito nacional.

A título de exemplo, Marcos Fuchs ${ }^{18}$ afirma que o Estado de São Paulo demorou dezesseis anos até que finalmente implementasse a Defensoria Pública em seu território, enquanto Santa Catarina foi o último ente federativo a cumprir a referida determinação, apenas em 2012.

Assim sendo, não obstante haja, atualmente, a criação das Defensorias Públicas em todos os Estados da federação, certo é que sua implementação ainda não se deu de forma efetiva e plena em todo o país, principalmente se levar em consideração as regiões mais pobres e afastadas dos grandes centros.

Acrescentam os autores Humberto Henrique Costa Fernandes do Rêgo e Victor dos Santos Maia Matos ${ }^{19}$, que a referida instituição apresenta falta de capilaridade e estrutura, tanto material, quanto humana.

Diante dessa carência, a Defensoria Pública possui bastante dificuldade de expansão nas regiões, bem como, nos lugares onde já está implementada, a prestação dos serviços jurídicos gratuitos àqueles que necessitam se revela precária e insuficiente.

A fim de evidenciar a falta de estrutura humana das Defensorias Públicas, o secretário de Reforma do Judiciário, Flavio Crocce Caetano ${ }^{20}$, apresentou dados do Atlas de Acesso à Justiça referente ao ano de 2013, os quais apontam que os defensores públicos atingem apenas $40 \%$ das comarcas estaduais e $22 \%$ das federais.

\footnotetext{
${ }^{18}$ FUCHS, Marcos Roberto. Advocacia pro bono e o novo Código de Ética e Disciplina. Revista do Advogado da AASP, n. 129, abril de 2016. Pp. 72-79.

19 RÊGO, Humberto Henrique Costa Fernandes do e Victor dos Santos Maia Matos. Ética profissional e advocacia pro bono: o papel do advogado na conquista da cidadania. Revista do Advogado da AASP, n. 129, abril de 2016. Pp. 47-53.

${ }^{20}$ CANÁRIO, Pedro. Advogados se voltam contra Resolução Pro Bono da OAB-SP. Disponível em <http://www.conjur.com.br/2013-fev-23/grandes-nomes-advocacia-voltam-resolucao-probono-oab-sp>. Acesso em: 10/10/2016. >. Acesso em: 10/10/2016.
} 
Cumpre ressaltar, por oportuno, que o Atlas de Acesso à Justiça ${ }^{21}$ atualizado demonstra que, entre os anos de 2013 e 2015, não houve uma alteração significativa quanto à situação dos Estados no que tange à quantidade de portas de entrada da justiça existentes em cada ente. Todavia, o Índice Nacional de Acesso à Justiça (INAJ) apresentou uma tendência de melhoria, ainda que de forma bem reduzida.

Paralelamente a isso, conforme explanado em tópico anterior, certo é que a maior parte da população brasileira não possui recursos financeiros para arcar com os honorários de um advogado particular, deixando a cargo da Defensoria Pública a tutela dos interesses de milhares de brasileiros.

Dessa forma, conclui-se que a referida instituição, por si só, não é capaz de suprir a demanda de hipossuficientes existente em nosso país, razão pela qual, em última análise, o Estado não consegue cumprir o seu dever constitucional de prover o pleno acesso à justiça.

Importante ressaltar que a própria Declaração Pro Bono para as Américas $^{22}$ reconhece a insuficiência do Estado no que tange à garantia do acesso à justiça, evidenciando a necessidade de outros meios capazes de fornecer assistência jurídica gratuita, tendo em vista afirmar o seguinte:

"CONSIDERANDO QUE nem todos os membros da sociedade têm um acesso significativo às cortes e à representação legal efetiva, e isso sendo especialmente o caso para as pessoas e grupos pobres e desprivilegiados;

CONSIDERANDO QUE governos têm recursos limitados para dedicar às necessidades legais cruciais dos individuais pobres e desprivilegiados muitas vezes deixando as necessidades não atendidas;"

Insta salientar que a violação do direito fundamental de acesso à justiça acarreta gravíssimas consequências para o país, sendo, inclusive, um dos principais responsáveis pelas mazelas da sociedade, como se demonstrará a seguir.

\footnotetext{
${ }^{21}$ BRITO, Lany Cristina Silva, Gabriella Vieira Oliveira Gonçalves, Ministério da Justiça, Secretaria de reforma do Judiciário (SRJ). Atlas de Acesso à Justiça: indicadores nacionais de acesso à justiça. Brasília: Ministério da Justiça, Secretaria de Reforma do Judiciário, 2015. Disponível em: <http://www.acessoajustica.gov.br/pub/_downloads/caderno_inaj_2015.pdf>. Acesso em: 08/10/2016.

${ }^{22}$ Declaração Pro Bono das Américas. Disponível em: http://www.dhnet.org.br/direitos/deconu/a_pdf/declaracao_probono_para_as_americas.pdf.. Acesso em: 24/07/2016.
} 
Primeiramente, o indivíduo que vê seu direito reiteradamente violado, sem conseguir qualquer forma de auxílio para fazer cessar tal lesão, acaba por paulatinamente perder a fé no compromisso do sistema jurídico pela justiça e nas próprias instituições governamentais.

Por essa razão, asseveram Nádia Barros e Marcos Fuchs ${ }^{23}$ que a inacessibilidade da prestação jurídica mina o Estado de Direito e a crença na própria democracia.

Paralelamente à falta de credibilidade do sistema jurídico, a escassez do acesso à justiça possui como uma das principais consequências o aumento da violência no país, razão pela qual se pode justificar o alto grau de violência no Brasil encontrado atualmente.

Nesse diapasão, Miguel Reale Júnior ${ }^{24}$ afirma que um Estado ausente, principalmente no tocante à assistência jurídica, enseja a vindicta privada, caracterizada pela famigerada "justiça com as próprias mãos", culminando na banalização da vida.

Isso ocorre, pois se o Poder Judiciário, por não ter sido provocado, não é capaz de proporcionar uma solução justa e equilibrada a determinado litígio, os particulares automaticamente irão resolver a questão, a fim de substituir o Estado.

Outra consequência desencadeada pela precariedade do acesso à justiça consiste no aumento da desigualdade social, pois impede o cidadão de conhecer seus direitos e, portanto, se reconhecer como sujeito de direitos, bem como o inviabiliza de obter qualquer tutela jurisdicional, a fim de fazer cessar eventual violação dos seus direitos.

Por todo o acima exposto, conclui-se que a assistência jurídica gratuita proveniente do Poder Público, apesar de ter representado um grande avanço na efetivação do acesso à justiça após se tornar expressamente obrigatória através da Constituição Federal de 1988, não é

\footnotetext{
${ }^{23}$ BARROS, Nádia e Marcos Roberto Fuchs. Por que os advogados não podem atender de graça? Disponível em: <http://reporterbrasil.org.br/2013/12/por-que-os-advogados-brasileiros-naopodem-atender-de-graca/>. Acesso em: 22/07/2016.

${ }^{24} \mathrm{JÚN}$ IOR, Miguel Reale. Advocacia pro bono: ocupação feliz. Revista do Advogado da AASP, $\mathrm{n}$. 129, abril de 2016. Pp. 105-109.
} 
capaz de, por si só, suprir a demanda existente em um país tão desigual e miserável quanto o nosso.

Assim sendo, mister se faz a presença de outras modalidades de assistência jurídica gratuita, capazes de complementar o serviço insuficiente prestado pelo Estado.

Seguindo esse diapasão, a fim de ampliar o acesso à justiça, efetivar os direitos dos cidadãos e garantir os direitos fundamentais, desenvolve-se cada vez mais em território brasileiro, seguindo uma tendência mundial, a consciência da responsabilidade social por parte do setor privado, visando dirimir as máculas existentes na sociedade, conforme será demonstrado a seguir.

\subsection{A responsabilidade social da advocacia}

\subsubsection{Breve desenvolvimento da responsabilidade social no Brasil}

Pelo exposto nos tópicos anteriores, não obstante o Brasil seja um país de proporções continentais, cuja economia encontra-se entre as dez maiores do mundo, sua população ainda vive em meio à extrema desigualdade socioeconômica, principalmente no tocante ao acesso à justiça.

Pode-se dizer que esse fato é consequência da incapacidade do Estado, devido a diversos fatores, de cumprir com os objetivos fundamentais que lhe são impostas pelo artigo $3^{\circ}$ da Constituição da República, quais sejam: construir uma sociedade livre, justa e igualitária, erradicar a pobreza e a marginalização, bem como reduzir as desigualdades sociais e regionais.

Destarte, os membros da sociedade, percebendo a supracitada insuficiência estatal e suas consequências negativas, começaram a suprir, no âmbito privado, essas lacunas, tomando para si parte da responsabilidade de 
construir uma sociedade melhor, o que ensejou a noção de responsabilidade social.

Nessa esteira, Oscar Vilhena Vieira ${ }^{25}$ afirma que durante os governos autoritários e a redemocratização, a sociedade civil passou a se organizar, a fim de pressionar o Estado para que se tornasse mais responsável, bem como para propor políticas alternativas com o intuito de amenizar o triste quadro social.

Ressalte-se, por oportuno, conforme salienta Miguel Reale Júnior ${ }^{26}$, que inicialmente as empresas privadas acreditavam estarem cumprindo com sua função social à medida que pagavam os impostos e geravam empregos, sendo certo que qualquer atuação social praticada pelo setor privado possuía caráter meramente filantrópico e caritativo.

Isso porque a responsabilidade social era vista de forma dissociada da função social empresarial, eis que se entendia que o Estado era o único responsável pelas ações sociais.

Todavia, segundo o supracitado autor, a mentalidade de que os Governos eram os únicos responsáveis pelas causas sociais foi paulatinamente sendo substituída por uma nova concepção de responsabilidade social, na qual os indivíduos e as empresas compreendem seu dever para com o ambiente onde estão inseridos.

Dessa forma, a noção de responsabilidade social, até então limitada ao simples cumprimento do contrato social de uma empresa, amplia-se para uma preocupação com o bem estar das minorias, do meio ambiente e dos hipossuficientes de modo geral por parte de todos os indivíduos da sociedade.

Assim, a partir dessa nova concepção, ressalta Fernando Modé ${ }^{27}$ que a responsabilidade social das empresas passou a ser entendida como uma

\footnotetext{
${ }^{25}$ VIEIRA, Oscar Vilhena. A desigualdade e a subversão do Estado de Direito. Revista Internacional de Direito e Cidadania, n. 1, junho/2008. Pp. 185-201.

26 JÚNIOR, Miguel Reale. Responsabilidade Social. Disponível em: <http://www.probono.org.br/advocacia-pro-bono/entenda>. Acesso em: 03/05/2016.

${ }^{27}$ MODÉ, Fernando Magalhães. A função social do advogado e a advocacia pro bono. Belo Horizonte: Revista de Direito do Terceiro Setor - RDTS. Ed.: ano 1, n. 1, jan/ jun. 2007.
} 
conduta empresarial ética e responsável, sendo certo que suas ações, posturas e valores possuem estrita relação com todos os interlocutores da empresa, desde funcionários até clientes.

Acrescenta o autor que as pessoas, portanto, individualmente ou em grupo, começaram a elaborar diversos estudos e a pôr em prática inúmeras ações de cunho social, ambiental e econômico, sem auxílio governamental, a fim de melhorar a qualidade de vida da população.

Por todo o exposto, extrai-se que diante da insuficiência estatal em construir uma sociedade justa e igualitária, os particulares passaram a se organizar para proporcionar o bem estar da comunidade na qual estão inseridos. Importante ressaltar, contudo, que essa responsabilidade social, inicialmente empresarial, se entranhou também na mentalidade dos profissionais do Direito, como se verá a seguir.

\subsubsection{Responsabilidade social da advocacia como instrumento transformador da sociedade brasileira}

Conforme anteriormente exposto, o Estado não é capaz de, por si só, cumprir integralmente seu dever constitucional de prover assistência jurídica gratuita a todos os que dela necessitam. Por outro lado, os valores dos honorários advocatícios e das custas judiciais, por serem bastante onerosos, tornam-se inacessíveis a grande parte da população.

Assim sendo, a sociedade, a partir da combinação de esforços de diferentes setores, vem desenvolvendo alternativas para suprir a ausência do Estado quanto à promoção e democratização do acesso à justiça.

Nessa vereda, o Instituto Pro Bono ${ }^{28}$, organização da sociedade civil responsável por fomentar a prática da advocacia gratuita, voluntária e solidária entre os profissionais do ramo, acredita que a erradicação da

Disponível em: <http://www.editoraforum.com.br/ef/wp-content/uploads/2016/08/funcao-socialdo-advogado.pdf.>. Acesso em: 04/08/2016.

${ }^{28}$ BONO, Instituto Pro. Relatório Institucional 2012. Disponível em: <http://www.probono.org.br/arquivos/file/Relatorio2012.pdf>. Acesso em: 03/05/2016. 
"pobreza no sentido legal" compete também à sociedade e não só ao Estado.

Dessa forma, se o Governo se revela ineficiente, cabe à sociedade civil se articular para colaborar com a diminuição da miséria, em todos os seus sentidos, ao invés de permanecer inerte, eis que também possui a responsabilidade social de contribuir para uma sociedade mais igualitária.

Nesse contexto, o defensor público Marcos Henrique Caetano do Nascimento $^{29}$ faz a seguinte indagação: até que ponto os profissionais do Direito não são responsáveis pela aguda desigualdade social que assola o Brasil?

Ora, segundo salienta Marcos Henrique Caetano do Nascimento ${ }^{30}$, acredita-se que o advogado não só possui o múnus publico de prestar serviço gratuitamente aos necessitados, como também possui todos os meios e oportunidades para praticar tal atividade.

Por essa razão, o Estatuto da Advocacia ${ }^{31}$, em seu artigo $2^{\circ}$, dispõe que o advogado presta serviço público e exerce função social, razão pela qual sua atividade é indispensável à administração da justiça, conforme dispõe o artigo 133 da Constituição da República.

Ademais, um dos mandamentos previstos na Exposição de Motivos do Código de Ética da $\mathrm{OAB}^{32}$ consiste no fato do profissional do Direito exercer a advocacia com desprendimento, de modo a preferir cumprir com a finalidade social do seu trabalho do que a obter vantagens econômicas.

Imperioso, portanto, que os operadores do Direito não fiquem alheios à nova era da responsabilidade social.

\footnotetext{
${ }^{29}$ NASCIMENTO, Marcos Henrique Caetano do. Advocacia pro bono e a democratização do acesso à justiça. Revista Jurídica Consulex, ano XVII, n. 398, 15 de ago de 2013. Pp. 36-37.

${ }^{30}$ RÊGO, Humberto Henrique Costa Fernandes do e Victor dos Santos Maia Matos. Ética profissional e advocacia pro bono: o papel do advogado na conquista da cidadania. Revista do Advogado da AASP, n. 129, abril de 2016. Pp. 47-53.

${ }^{31}$ PLANALTO. Lei $n^{o}$ 8.906, de 04 de julho de 1994 -Estatuto da Advocacia e a Ordem dos Advogados do Brasil $(O A B)$. Brasília. Disponível em: <http://www.planalto.gov.br/ccivil_03/leis/L8906.htm >. Acesso em: 30/10/2016.

${ }^{32} \mathrm{OAB}$, Conselho Federal. Resolução n. 02/2015 - Código de Ética e Disciplina da Ordem dos Advogados do Brasil. Brasília: 19 de outubro de 2015. Disponível em: $\langle$ http://www.oab.org.br/arquivos/resolucao-n-022015-ced-2030601765.pdf〉. Acesso em: $30 / 10 / 2016$.
} 
O jurista José Renato Nalini ${ }^{33}$ destaca que o acesso à justiça consagrado no texto constitucional demanda a todo operador jurídico brasileiro um movimento de contínuo esforço para alargar a porta da justiça a todos, principalmente aos excluídos.

Insta salientar que é sabido que são vários os debates acerca da cultura jurídica excessivamente formalista dos advogados. Nessa seara, José Eduardo Faria $^{34}$, por exemplo, aponta como importante na profissão uma reflexão multidisciplinar capaz de desvendar as relações sociais subjacentes às normas e às relações jurídicas a partir de novas informações e/ou informações reformuladas.

Não obstante o supracitado, o autor Fernando Modé ${ }^{35}$ afirma que esses profissionais, devido à formação técnica e humanística que possuem, se revelam qualificados como agentes transformadores da realidade socioeconômica na qual estão inseridos.

Acrescenta, ainda, que o advogado, ao unir suas habilidades funcionais a uma postura ética e socialmente responsável para prestar assistência jurídica gratuita aos indivíduos, principalmente aos hipossuficientes, cumpre com a função social de sua profissão.

$\mathrm{Na}$ mesma seara, Celso Cintra Mori ${ }^{36}$ destaca que ao advogado incumbe a função de compensar as deficiências e obstáculos geradores da má distribuição da justiça, a fim de que a cidadania seja alcançada plenamente por todos os brasileiros.

Dessa forma, extrai-se que a responsabilidade social do advogado se materializa no campo do acesso à justiça, tendo em vista que suas habilidades funcionais e seu conhecimento jurídico o permitem

\footnotetext{
${ }^{33}$ NALINI, José Renato. O juiz e o acesso à justiça. São Paulo: RT, 2000.

${ }^{34}$ FARIA, José Eduardo. In: Formação jurídica. (coord.) José Renato Nalini. São Paulo: RT, 1999, p. 19

${ }^{35}$ MODÉ, Fernando Magalhães. A função social do advogado e a advocacia pro bono. Revista de Direito do Terceiro Setor - RDTS, ano 1, n. 1, jan/ jun. 2007. Disponível em: http://www.editoraforum.com.br/ef/wp-content/uploads/2016/08/funcao-social-doadvogado.pdf.>. Acesso em: 04/08/2016.

${ }^{36}$ MORI, Celso Cintra. Democratização do acesso à Justiça. Disponível em: <http://www.probono.org.br/advocacia-pro-bono/entenda.>. Acesso em: 03/05/2016.
} 
proporcionar soluções justas e civilizadas àqueles que, em decorrência da insuficiência estatal, estariam à margem da chancela do Poder Judiciário.

A partir da conscientização do exposto acima, Paulo Afonso da Motta Ribeiro ${ }^{37}$ afirma ser possível observar, na história recente brasileira, a repercussão da responsabilidade social no âmbito jurídico, à medida que diversas entidades foram criadas com o objetivo de prover assistência jurídica gratuita suplementar à estatal, bem como inúmeras ações foram desenvolvidas pelos profissionais da área, tendo como exemplo os mutirões legais e as ações nacionais de cidadania.

Insta salientar que o voluntariado no Direito pode se manifestar de diversas formas, desde a orientação jurídica até a propositura de demandas no Poder Judiciário. Igualmente, a responsabilidade social da advocacia pode ser praticada por qualquer pessoa da área, desde o estudante até o jurista mais renomado, bem como por pessoas jurídicas, cuja função seja democratizar o acesso à justiça. ${ }^{38}$

Dentre os exemplos de prática solidária no meio jurídico, podem ser destacados os Núcleos de Prática Jurídica das faculdades de Direito (NPJ), as organizações da sociedade civil (OSCIP) e organizações não governamentais (ONGS) destinadas tanto a fomentar a prática do voluntariado entre os alunos e profissionais da área, quanto a prestar assistência jurídica gratuita a quem necessita, e, por fim, a advocacia pro bono, objeto do presente trabalho que melhor será tratado no capítulo seguinte.

Por todo o exposto, conclui-se que devido à consciência cada vez maior acerca da função social da advocacia, inúmeros advogados passaram a doar uma parcela de seu tempo para prestar assessoria jurídica de forma graciosa aos economicamente hipossuficientes, visando materializar os

\footnotetext{
${ }^{37}$ RIBEIRO, Paulo Afonso da Motta. O significado da advocacia pro bono. São Paulo: Revista Jurídica Consulex, ano XVII, n. 398, 15 de ago de 2013. P. 32-34.

38 STRAUSS, Daniel et al. Advocacia de interesse público e voluntariado. Disponível em: <http://livro.educardpaschoal.org.br/upload/NossosLivros/61_livro_advocacia.pdf>. Acesso em: 08/05/2016.
} 
direitos daqueles que, provavelmente, estariam excluídos de qualquer chancela do Poder Judiciário.

Nesse sentido, importante o apoio subsidiário dos núcleos de prática jurídica das universidades e das diversas ONG's que se dedicam à prestação do serviço jurídico gratuito, tendo em vista a incapacidade do Estado em atender a demanda. A advocacia pro bono, como será mais a frente debatido, igualmente representa uma possibilidade supletiva de atendimento as necessidades da população pobre. 


\section{CAPÍTULO 2 - ADVOCACIA PRO BONO}

\subsection{ADVOCACIA PRO BONO: AFINAL DO QUE SE TRATA?}

\subsubsection{Histórico}

Decerto, a advocacia consiste em uma profissão remunerada, através da qual seus operadores auferem renda para que possam sustentar a si e as suas famílias. Dessa forma, a cobrança dos honorários advocatícios como contraprestação de seus serviços jurídicos é, além de legítima, necessária.

Ocorre que, sob um prisma filosófico-liberal, os advogados são considerados defensores das liberdades humanitárias, políticas e filosóficas, cuja atuação se dá em favor da manutenção e aplicação da ordem jurídica aos casos concretos, assegurando, em última análise, o Estado de Direito. ${ }^{39}$

Por essa razão, não obstante seu caráter econômico, a advocacia é praticada de forma graciosa aos economicamente necessitados desde a época da escravatura, inclusive pelos mais notáveis advogados da história, sendo certo que no Império foi criado o cargo "Advogado dos Pobres". 40

Admite-se que o exímio rábula Luís Gama e o renomado jurista Rui Barbosa foram os percussores da advocacia gratuita no Brasil, eis que já no século XIX atuavam em causas abolicionistas sem exigir qualquer contraprestação. ${ }^{41}$

A nobre atuação desses juristas inspirou inúmeros profissionais que, percebendo a função social que a advocacia exerce na sociedade, optaram por doar parte de seu tempo para prestar serviços gratuitamente aos desprivilegiados, razão pela qual tal prática foi sendo disseminada cada vez mais no território brasileiro.

\footnotetext{
${ }^{39}$ ARAÚJO, Thiago Cássio D’Ávila. Conceito e características da advocacia. Disponível em: $<$ https://jus.com.br/artigos/8324/conceito-e-caracteristicas-da-advocacia>. Acesso em: 30/10/2016. ${ }^{40}$ FUCHS, Marcos Roberto e Flávia Piovesan. Advocacia de interesse público e o instituto pro bono. Revista Jurídica Consulex, ano XVII, n. 398, 15 de ago de 2013. Pp. 40-42.

${ }^{41}$ FUCHS, Marcos Roberto e Flávia Piovesan. Advocacia de interesse público e o instituto pro bono. Revista Jurídica Consulex, ano XVII, n. 398, 15 de ago de 2013. Pp. 40-42.
} 
Cumpre ressaltar, por oportuno, que a prestação jurídica gratuita realizada por profissionais autônomos sempre foi praticada de forma livre e desimpedida, sem que acarretasse qualquer forma de sanção por parte do Tribunal de Ética ou de outro órgão similar. ${ }^{42}$

Assim sendo, como acima demonstrado, os advogados sempre desempenharam papel de extrema relevância na sociedade brasileira, à medida que, como aliados da Justiça, prestavam um serviço público essencial à dignidade da pessoa humana, fazendo valer o direito de ter direitos. $^{43}$

Ocorre que, conforme observa o advogado Paulo Afonso da Motta Ribeiro $^{44}$, as atuações individualizadas e difusas de assistência jurídica gratuita prestada pelos advogados, não obstante seu caráter nobre, não condizem com as necessidades da sociedade contemporânea, uma vez que não caracterizam um esforço significativo no sentido de supri-las.

A partir da percepção supramencionada, os advogados interessados e estudantes do tema, atentos à responsabilidade social da advocacia, começaram a buscar meios para, através da profissão, transformar a realidade social, caracterizada pela desigualdade, violência e inacessibilidade da justiça pela maior parte da população.

Cumpre ressaltar, por oportuno, que nesse ponto houve considerável influência da cultura norte-americana, tendo em vista sua larga experiência em serviço pro bono realizado por praticamente todos os escritórios de advocacia do país, eis que não há, nos Estados Unidos, assistência jurídica gratuita pública em causas cíveis.

De acordo com um dos maiores entusiastas do tema, Marcos Roberto Fuchs $^{45}$, os bacharéis de direito norte-americanos que passam no $B A R$

\footnotetext{
${ }^{42}$ D’URSO, Luiz Flávio Borges. Advocacia pro bono precisa de regras nacionais. Revista Jurídica Consulex, ano XVII, n. 398, 15 de ago de 2013. P. 35.

${ }^{43}$ FUCHS, Marcos Roberto. Advocacia pro bono e o novo Código de Ética e Disciplina. Revista do Advogado da AASP, n. 129, abril de 2016. Pp. 72-79.

${ }^{44}$ RIBEIRO, Paulo Afonso da Motta. O significado da advocacia pro bono. São Paulo: Revista Jurídica Consulex, ano XVII, n. 398, 15 de ago de 2013. Pp. 32-34.

${ }^{45}$ Entrevista realizada pela autora da monografia Hannah Rabe com Marcos Roberto Fuchs, fundador do Instituto Pro Bono, em 07/11/2016.
} 
Exam, equivalente à prova da $\mathrm{OAB}$ brasileira, devem realizar 60 horas de serviços pro bono, a fim de conseguirem a habilitação para exercer a profissão, o que dissemina a cultura da responsabilidade social na advocacia.

Ademais, segundo o sócio do escritório norte-americano Thompson \& Knight LLP, Marcello Hallake, em entrevista realizada pela repórter da revista Consultor Jurídico, Gabriela Invernizzi ${ }^{46}$, a maioria dos clientes optam por bancas que praticam, de forma efetiva, a advocacia pro bono, como é o caso da General Eletric.

Seguindo essa tendência mundial, em 2001, um grupo de 35 advogados, dentre eles Marcos Roberto Fuchs e Oscar Vilhena Vieira, criaram o Instituto Pro Bono (IPB), classificado como Organização da Sociedade Civil de Interesse Público (Oscip), cuja intenção era institucionalizar e organizar a advocacia pro bono, até então praticada de modo difuso e assistemático.

Os idealizadores do $\operatorname{IPB}^{47}$ entendiam que, ao organizar a prestação de assistência jurídica gratuita em um trabalho pro bono comprometido, coordenado e regular, estar-se-ia contribuindo de modo efetivo para a materialização dos direitos daqueles juridicamente excluídos, maximizando, em última análise, o acesso à justiça.

Para atingir tal fim, a entidade adota as seguintes medidas: (i) a fomentação da prática da advocacia solidária, (ii) a prestação de assessoria jurídica gratuita, (iii) a difusão do conhecimento jurídico à população e (iv) a conscientização dos advogados quanto à responsabilidade social de sua profissão. $^{48}$

Importante ressaltar que o Instituto Pro Bono se revelou um ente de fundamental importância na construção e no desenvolvimento da advocacia

\footnotetext{
${ }^{4646}$ INVERNIZZI, Gabriela. Advocacia Pro Bono cresce e melhora imagem de escritórios. Disponível em: <http://www.conjur.com.br/2007-dez08/advocacia_pro_bono_cresce_melhora_imagem_escritorios>. Acesso em: 09/06/2016.

${ }^{47}$ NASCIMENTO, Marcos Henrique Caetano do. Advocacia pro bono e a democratização do acesso à justiça. Revista Jurídica Consulex, ano XVII, n. 398, 15 de ago de 2013. Pp. 36-37.

${ }^{48} \mathrm{JÚN}$ IOR, Miguel Reale. Advocacia pro bono: ocupação feliz. Revista do Advogado da AASP, $\mathrm{n}$. 129, abril de 2016. Pp. 105-109.
} 
pro bono no Brasil, eis que colaborou intensamente para a criação de uma regulamentação da atividade em âmbito nacional, bem como realizou diversas parcerias com grandes escritórios de advocacia, incentivando e desenvolvendo o pro bono de forma estruturada.

Segundo afirma Marcos Fuchs ${ }^{49}$, os escritórios de advocacia Mattos Filho, Pinheiro Neto e Siqueira Castro são exemplos de grandes firmas parceiras que possuem uma estrutura interna destinada especialmente a atender a demanda pro bono, bem como adotam políticas de incentivo em relação aos seus associados.

Ressalte-se, por oportuno, que a advocacia pro bono foi formalizada no escritório Siqueira Castro após diversos clientes estrangeiros questionarem sobre as práticas sociais desenvolvidas pela banca, fato que evidencia a tendência mundial acerca da responsabilidade social na advocacia. ${ }^{50}$

Por todo o exposto nesse tópico, conclui-se que a advocacia gratuita sempre existiu, porém, nas últimas décadas, expandiu seus horizontes, ao passo que não mais se limitou um modelo de voluntariado assistemático, difuso e esporádico, tendo em vista que passou a ser exercida através de parâmetros de organização, metodologia e capacitação, bem como possui uma regulamentação a nível nacional.

Como consequência, a advocacia pro bono, devido ao seu largo alcance, contribui de forma efetiva para a ampliação do acesso à justiça na sociedade brasileira.

\footnotetext{
${ }^{49}$ FUCHS, Marcos Roberto. Advocacia pro bono e o novo Código de Ética e Disciplina. Revista do Advogado da AASP, n. 129, abril de 2016. Pp. 72-79.

${ }^{50}$ INVERNIZZI, Gabriela. Advocacia Pro Bono cresce e melhora imagem de escritórios. Disponível em: 08/advocacia_pro_bono_cresce_melhora_imagem_escritorios>. Acesso em: 09/06/2016.
} 


\subsubsection{Conceito}

Conforme expresso na Declaração Pro Bono das Américas ${ }^{51}$, a expressão "pro bono" deriva do brocardo latino "pro bono publico", o qual significa "para o bem do público". Dessa forma, quando se fala em trabalho pro bono lato sensu, entende-se como uma atividade gratuita, solidária e voluntária visando o bem da sociedade.

No âmbito do Direito, a advocacia pro bono, também denominada de advocacia solidária, consiste em uma prestação de serviços jurídicos oferecidos de forma gratuita, solidária e voluntária às pessoas jurídicas ou físicas que não possuem recursos financeiros para custear os honorários de um advogado.

O Código de Ética e Disciplina da $\mathrm{OAB}^{52}$, em seu artigo 30, conceituou a advocacia pro bono da seguinte forma:

"prestação gratuita, eventual e voluntária de serviços jurídicos em favor de instituições sociais sem fins econômicos e aos seus assistidos, sempre que os beneficiários não disporem de recursos para a contratação de profissional". ${ }^{53}$

Insta salientar, ainda, que em seu parágrafo segundo, o referido dispositivo prevê expressamente a possibilidade de a advocacia solidária ser exercida também em favor de pessoas físicas, nas hipóteses em que as mesmas não puderem contratar um advogado sem prejuízo de seu próprio sustento ou do de sua família.

Quanto ao agente, Luiz Flávio Borges D’Urso ${ }^{54}$ acrescenta que a atividade pro bono pode ser exercida tanto por advogados autônomos, quanto por pessoas jurídicas.

\footnotetext{
${ }^{51}$ Declaração Pro Bono das Américas. Disponível em: <http://www.dhnet.org.br/direitos/deconu/a_pdf/declaracao_probono_para_as_americas.pdf.>. Acesso em: 24/07/2016.

${ }^{52}$ FUCHS, Marcos Roberto. Advocacia pro bono e o novo Código de Ética e Disciplina. Revista do Advogado da AASP, n. 129, abril de 2016. Pp. 72-79.

53 OAB, Conselho Federal. Resolução n. 02/2015 - Código de Ética e Disciplina da Ordem dos Advogados do Brasil. Brasília: 19 de outubro de 2015. Disponível em: <http://www.oab.org.br/arquivos/resolucao-n-022015-ced-2030601765.pdf>. Acesso em: 30/10/2016.

54 D’URSO, Luiz Flávio Borges. Advocacia pro bono precisa de regras nacionais. Revista Jurídica Consulex, ano XVII, n. 398, 15 de ago de 2013. P. 35.
} 
Cumpre observar, por oportuno, conforme exposto em tópico anterior, que a advocacia pro bono ultrapassa os limites da atuação gratuita e individual do advogado em prol de quem necessita, tendo em vista que consiste em um trabalho amplo, comprometido e coordenado, produzindo efeitos em nível municipal, estadual e nacional no sentido de democratizar o acesso à justiça. ${ }^{55}$

Por essa razão, os professores Rubens Naves e Guilherme Amorim Campos da Silva ${ }^{56}$, afirmam haver as seguintes modalidades de advocacia solidária: a advocacia pro bono propriamente dita e a advocacy.

Segundo os autores, a grande diferença existente entre as duas modalidades é que a primeira visa tutelar direitos individuais dos hipossuficientes, enquanto a advocacy busca efetivar e aperfeiçoar políticas públicas, a fim de que sejam garantidos direitos coletivos.

Dessa forma, a advocacy transcende ao direito individual, ao passo que defende causas sociais de interesse público, atuando majoritariamente no campo político.

Imperioso ressaltar, por fim, que a advocacia pro bono visa proporcionar conhecimento jurídico às pessoas, bem como assegurar a defesa de seus direitos em juízo, a fim de que os indivíduos excluídos da sociedade tenham suas pretensões tuteladas, bem como implementar direitos coletivos através de articulações políticas.

Por todo o exposto, extrai-se que a advocacia pro bono caracteriza-se precipuamente pela prestação gratuita, voluntária e solidária de serviços jurídicos destinados aos juridicamente hipossuficientes, cujo objetivo principal consiste, em última análise, na transformação da realidade social através da promoção do acesso integral à justiça.

\footnotetext{
${ }^{55}$ NASCIMENTO, Marcos Henrique Caetano do. Advocacia pro bono e a democratização do acesso à justiça. Revista Jurídica Consulex, ano XVII, n. 398, 15 de ago de 2013. Pp. 36-37.

${ }^{56}$ NAVES, Rubens e Guilherme Amorim Campos da Silva. Advocacia pro bono e advocacy. Revista Jurídica Consulex, ano XVII, n. 398, 15 de ago de 2013. Pp. 38-39.
} 


\subsubsection{Regulamentação inicial e o papel da $O A B$}

Conforme assinalado anteriormente, a advocacia pro bono no Brasil se difundiu consideravelmente nas últimas décadas, razão pela qual, devido à incansável luta de inúmeros advogados e organizações da sociedade civil, se institucionalizou e passou a ser realizada de forma organizada e regular.

Ocorre que, devido às proporções atingidas pela referida prática, essa não tardou a se tornar alvo de críticas por parte de diversos setores do meio jurídico, inclusive de algumas Seccionais da Ordem dos Advogados do Brasil.

Assim sendo, conforme ressaltou Flávio D'Urso ${ }^{57}$, a advocacia pro bono, entendida como uma prestação gratuita de serviços jurídicos realizados tanto por pessoas físicas, quanto jurídicas, de forma regular e sistemática, pugna por uma regulamentação clara, a fim de evitar que a advocacia solidária viole princípios norteadores da advocacia.

Dessa forma, no presente tópico pretende-se analisar o caminho percorrido até a efetiva regulamentação da atividade pro bono em âmbito nacional, por meio do Código de Ética e Disciplina da OAB, bem como todos os seus percalços.

Em âmbito nacional, o Conselho Nacional de Justiça, não obstante a ausência de força normativa de suas resoluções, foi o primeiro órgão a disciplinar a advocacia solidária, através da Resolução n $n^{0} 62 / 2009^{58}$, a fim de determinar que os tribunais adotem, estimulem e fomentem a prática da advocacia pro bono.

O supracitado documento, considerando o limitado acesso à justiça que temos em nosso país, evidenciou a urgência em adotar medidas eficazes, a fim de garantir às pessoas o pleno exercício de seus direitos, bem como a ampla defesa de seus interesses.

\footnotetext{
57 D’URSO, Luiz Flávio Borges. Advocacia pro bono precisa de regras nacionais. Revista Jurídica Consulex, ano XVII, n. 398, 15 de ago de 2013. P. 35.

${ }^{58}$ JUSTIÇA, Conselho Nacional de. Resolução n. 62 de 10 de fevereiro de 2009. Disponível em: 〈http://www.cnj.jus.br/images/stories/docs_cnj/resolucao/rescnj_62.pdf >. Acesso em: 18/07/2016.
} 
Ademais, o Conselho Nacional de Justiça, na época presidido pelo ministro Gilmar Mendes, ressaltou a importância da atuação conjunta de todos os órgãos que compõem o Sistema de Justiça, isto é, a Magistratura, o Ministério Público e a Defensoria Pública, visando a orientação jurídica e a defesa dos hipossuficientes, até que a Defensoria Pública esteja plenamente estruturada em todo o Brasil e seja capaz de atender a enorme demanda de seus serviços.

A Resolução n ${ }^{\circ}$ 62/2009 determinou, ainda, que a advocacia solidária fosse realizada de duas maneiras, sendo a primeira uma iniciativa decorrente exclusivamente dos tribunais, os quais providenciariam meios de cadastramento de advogados interessados em prestar assistência jurídica gratuita e adotariam medidas de ampla divulgação.

A segunda forma de viabilização da advocacia pro bono seria através de convênios firmados entre os tribunais e as instituições de ensino, onde a assistência jurídica gratuita seria realizada por estagiários regularmente inscritos na Ordem dos Advogados e cuja supervisão seria realizada por advogados orientadores contratados pela própria instituição escolar.

Cumpre salientar, por oportuno, que o Conselho Nacional de Justiça se preocupou em não diminuir o papel da Defensoria Pública, tendo em vista que estabelece a prática da advocacia solidária nas áreas em que aquela for menos incidente, sendo certo que os tribunais consultarão o referido órgão sobre os lugares mais carentes de assistência jurídica gratuita, nos termos do artigo 10 da Resolução.

Ocorre que, se a nível nacional a supracitada Resolução foi a única regulamentação acerca do tema antes do vigente $\mathrm{CED}$, certo é que, no âmbito estadual, a advocacia pro bono recebeu os mais diversos tratamentos, variando consideravelmente de Estado para Estado.

Insta salientar que no caso de São Paulo, havia, de um lado, uma sociedade jurídica organizada pugnando por uma regulamentação efetiva da advocacia pro bono e, doutro lado, uma seccional da $\mathrm{OAB}$ que adotou 
postura fortemente contrária à institucionalização dessa prática, razão pela qual o Estado em questão necessita ser estudado em tópico próprio.

\subsubsection{Posicionamentos das Seccionais da Ordem dos Advogados do Brasil dos Estados do Rio de Janeiro, Alagoas e Minas Gerais antes do Código de Ética vigente}

No presente item serão analisados os posicionamentos de algumas Seccionais da $\mathrm{OAB}$ anteriores ao CED atual, a fim de que seja criado um panorama geral em âmbito estatal acerca do assunto, para tão somente após ser destrinchada a situação paulista, principal responsável pela regulamentação nacional dada pelo Conselho Federal da OAB, no CED.

Destarte, no que tange à seccional do Rio de Janeiro da Ordem dos Advogados do Brasil, o Procurador Geral Fábio Nogueira, em entrevista realizada ${ }^{59}$, ressaltou que havia um debate acerca da institucionalização da advocacia pro bono em conflito com a previsão constitucional que determina a implementação das Defensorias Públicas nos Estados, ocasionando dúvidas quanto à possibilidade de existência simultânea das duas modalidades de assistência jurídica gratuita.

Assim sendo, segundo Fábio Nogueira, a discussão no âmbito da seccional consistia em buscar uma solução para o tema, na qual fosse viável atender os interesses dos hipossuficientes sem que fossem violados os preceitos legais.

Insta salientar, por oportuno, que o entrevistado informou não haver, até o presente momento, sequer um julgamento perante o Tribunal de Ética da OAB/RJ acerca da advocacia pro bono, o que leva a crer que a advocacia pro bono no Estado do Rio de Janeiro sempre foi realizada de forma livre e desimpedida por todo o advogado que a pretendesse desenvolver, sem que desta prática acarretasse sanções disciplinares.

\footnotetext{
${ }^{59}$ Entrevista realizada pela autora da monografia Hannah Dias Rabe com o Procurador Geral da OAB-RJ, Fábio Nogueira, em 11 de outubro de 2016.
} 
Isto porque, na $\mathrm{OAB}-\mathrm{RJ}$, vigorava o entendimento de que tudo o que não é proibido, é permitido. Assim, como a referida seccional aguardou o posicionamento oficial do Conselho Federal a respeito da advocacia pro bono, entendia-se que esta atividade não poderia sofrer restrições e, muito menos, sanções disciplinares.

Pela razão acima exposta, como afirma Pedro Canário ${ }^{60}$ em artigo publicado na revista eletrônica Consultor Jurídico, a supracitada seccional optou por se abster de regulamentar o exercício da advocacia solidária no Estado Fluminense, seja para incentivar ou restringir o exercício desta prática.

Diferentemente ocorreu no Estado do Alagoas, que, assim como São Paulo, editou Resolução a fim de regulamentar a atividade pro bono, na qual permitia o exercício desta atividade apenas em favor de ONGs, isto é, pessoas jurídicas sem fins lucrativos, integrantes do Terceiro Setor e que comprovadamente fossem desprovidas de recursos financeiros.

Ressalte-se, oportunamente, que no supracitado Estado era vedado qualquer prestação jurisdicional gratuita realizada por advogados às pessoas físicas, ainda que estas fossem beneficiárias de uma ONG.

Dessa forma, alguns profissionais possuíam receio de exercer a advocacia solidária em defesa de pessoas físicas hipossuficientes que necessitavam urgentemente de assistência jurídica gratuita, eis que, se o fizessem, poderiam sofrer um eventual processo disciplinar por desrespeitar a regulamentação vigente.

Insta salientar que de todos os entes federativos, apenas São Paulo e Alagoas emitiram resoluções sobre o tema, sendo certo que o fizeram para restringir e não para consolidar e ampliar a atividade pro bono.

Em relação ao Estado de Minas Gerais, apesar da respectiva seccional não ter regulamentado o tema em seu território, certo é que foram

\footnotetext{
${ }^{60}$ CANÁRIO, Pedro. OAB-SP já se pronunciou 20 vezes contra pro bono. Disponível em: $\langle$ http://www.conjur.com.br/2013-fev-26/oab-sp-pronunciou-20-vezes-advocacia-pro-bono〉. Acesso em: 27/07/2016.
} 
realizadas algumas consultas sobre a advocacia solidária perante o Tribunal de Ética e Disciplina.

Conforme Sérgio Leonardo, então secretário-geral adjunto da OABMG e diretor da Seccional mineira do Centro de Estudos de Sociedades de Advogados (CESA), o posicionamento desta Seccional é semelhante ao do adotado por São Paulo, tendo em vista que, como regra geral, a advocacia gratuita não é recomendada, sob o argumento de que existe uma tabela de honorários advocatícios, na qual estão determinados os valores mínimos a serem cobrados por um advogado.

Outro argumento da referida seccional consiste na possibilidade da advocacia solidária ser praticada não como uma ação social, mas sim como meio de captação de clientela, valendo-se o advogado deste instituto para sua promoção individual e ascensão na carreira, prejudicando o aspecto concorrencial.

Ressalta o então secretário-geral ${ }^{61}$, entretanto, que o Tribunal de Ética e Disciplina da OAB de Minas Gerais não deixa de observar a dignidade da pessoa humana e o acesso à justiça, sendo certo que, se ficar comprovado, no caso concreto, que o advogado prestou seus serviços gratuitamente a alguém hipossuficiente, que por outro meio não poderia fazer valer seu direito, será permitida a atuação pro bono.

Pelo até então exposto neste capítulo, extrai-se que, em razão da ausência de uma norma nacional capaz de uniformizar a atividade da advocacia pro bono, as Seccionais da Ordem dos Advogados, de acordo com seus próprios posicionamentos sobre o tema, davam tratamento diferenciado a essa prática, ensejando uma série de mal-entendidos. ${ }^{62}$

\footnotetext{
${ }^{61}$ CANÁRIO, Pedro. OAB-SP já se pronunciou 20 vezes contra pro bono. Disponível em: <http://www.conjur.com.br/2013-fev-26/oab-sp-pronunciou-20-vezes-advocacia-pro-bono>. Acesso em: 27/07/2016.

${ }^{62} \mathrm{OABRJ}$. Instituto Pro Bono elogia decisão da OAB. Disponível em: <http://www.oabrj.org.br/detalheConteudo/760/Instituto-Pro-Bono-elogia-decisao-da-OAB.html >. Acesso em: 08/06/2016.
} 
Passa-se, no momento, à análise do caso do Estado de São Paulo, responsável principal pela regulamentação da advocacia pro bono em âmbito nacional, isto é, o CED.

\subsubsection{A importância da seccional da OAB-SP no debate da regulamentação da advocacia pro bono em âmbito nacional}

O Estado de São Paulo foi palco de grandes acontecimentos e manifestações realizadas por parte da comunidade jurídica brasileira em prol da institucionalização da advocacia solidária.

Ressalte-se que as maiores discussões acercado tema ocorreram no território paulista por três principais razões, quais sejam: (i) São Paulo possui o maior contingente de advogados do Brasil; (ii) as maiores organizações da sociedade civil, cujo objetivo consiste em disseminar a cultura da advocacia pro bono em âmbito nacional, possuem suas respectivas sedes no Estado paulista; e (iii) a Seccional de São Paulo da Ordem dos Advogados do Brasil possuía ferrenha posição contrária à plena prática da advocacia solidária.

Primeiramente, a fim de entender tal postura, mister se faz a contextualização do panorama jurídico-social em que se encontrava o supracitado ente federativo, desde a promulgação da Constituição da República Federativa do Brasil, em 1988.

Destarte, conforme anteriormente ressaltado no presente trabalho, o Estado de São Paulo somente estabeleceu a Defensoria Pública em seu território após 16 anos da determinação legal dada pelo artigo 134 da nossa Carta Magna.

Assim sendo, a fim de suprir a latente demanda por assistência jurídica gratuita e, consequentemente, ampliar o tão escasso acesso à Justiça, o Poder Público realizou convênio com a seccional paulista da Ordem dos Advogados do Brasil, através do qual, mediante recursos públicos advindos do Fundo de Assistência Judiciária - FAJ, visa garantir 
atendimento jurídico gratuito às pessoas físicas que a Defensoria Pública não possui capacidade de atender. ${ }^{63}$

Ocorre que, não obstante o referido convênio, num primeiro momento, tenha colaborado para a ampliação do acesso à justiça, posteriormente revelou-se um monopólio de assistência jurídica gratuita - o que evidentemente não é função da $\mathrm{OAB}$-, bem como passou a obstara efetiva implementação da Defensoria Pública no Estado paulista.

Isto porque, conforme ressaltado pelo presidente da Associação Nacional de Defensores Públicos - ANADEP, André Luis Machado de Castro, e o presidente da APADEP, Rafael Morais Português de Souza ${ }^{64}$, em artigo publicado na Folha de São Paulo, estima-se que quase $70 \%$ do orçamento reservado à Defensoria Pública era destinado à $\mathrm{OAB} / \mathrm{SP}$, a fim de que esta contratasse e remunerasse os advogados dativos, o que empodera excessivamente o convênio celebrado e a referida entidade. Ademais, o supracitado convênio deixa de observar as normas gerais e obrigatórias à organização da Defensoria, não colaborando, assim, para o seu pleno desenvolvimento, eis que acaba por substituí-la.

Paralelo ao supramencionado, Marcos Fuchs ${ }^{65}$ assevera que diversos advogados e organizações da sociedade civil começaram a pressionar fortemente a seccional paulista, a fim de que a referida entidade regulamentasse a atividade da advocacia pro bono há anos exercida no país, visando institucionalizar sua prática, cujo crescimento era cristalino.

Entretanto, devido à existência do poderoso convênio firmado entre o Poder Público e a $\mathrm{OAB} / \mathrm{SP}$, aliado à forte pressão exercida pelos advogados dativos, os quais sustentavam que os advogados pro bono estariam reduzindo seus clientes em um mercado já escasso, a supracitada

\footnotetext{
${ }^{63} \mathrm{BONO}$, Instituto Pro. Convênio entre OAB e Defensoria Pública não é caracterizado como advocacia pro bono e pode ser celebrado com qualquer entidade. Disponível em: $<\mathrm{http}$ ://www.probono.org.br/convenio-entre-oab-e-defensoria-publica-nao-e-caracterizado-comoad vocacia-pro-bono-e-pode-ser-celebrado-com-qualquer-entidade>. Acesso em: 09/06/2016.

${ }^{64}$ CASTRO, André Luís Machado de e Rafael Morais Português de Souza. Retrocesso e Corporativismo. Disponível em: <http://wwwl.folha.uol.com.br/fsp/opiniao/61956-retrocesso-ecorporativismo.shtml $>$. Acesso em: 16/10/2016.

${ }^{65}$ FUCHS, Marcos Roberto. Advocacia pro bono e o novo Código de Ética e Disciplina. Revista do Advogado da AASP, n. 129, abril de 2016. Pp. 72-79.
} 
seccional adotou posicionamento contrário à referida atividade, sob o argumento de que estase coadunaria em captação de clientela e concorrência desleal.

Ressalte-se, por oportuno, que a questão da proibição da advocacia pro bono era tão recorrente que em 2001, em julgamento perante o Tribunal de Ética e Disciplina da OAB de São Paulo ${ }^{66}$, o referido órgão evidenciou a necessidade de uma regulamentação acerca da advocacia solidária, a fim de impor limites e evitar abusos que poderiam decorrer desta prática.

Seguindo esse diapasão, a seccional paulista estava ciente de que não poderia abster-se de regulamentar a referida atividade, tendo em vista que a comunidade jurídica pugnava veementemente por uma determinação normativa. Assim sendo, a OAB de São Paulo, após consultar diversos advogados, órgãos de classe e o Instituto Pro Bono, editou, em 19 de agosto de 2002, a Resolução Pro Bono, sendo certo que esta foi a primeira norma a dispor sobre a prática pro bono no país.

Ocorre que o supracitado documento, em verdade, serviu mais para restringir do que incentivar a advocacia pro bono, eis que limitava a atuação dos advogados solidários à defesa de pessoas jurídicas sem fins lucrativos integrantes do Terceiro Setor que comprovassem sua hipossuficiência financeira, sendo certo que a prestação de serviços jurídicos para pessoas físicas, mesmo que estas fossem beneficiárias das referidas instituições, era expressamente vedada.

Destarte, nos termos da Resolução Pro Bono, o advogado que pretendesse exercer a advocacia solidária, a fim de fazer cumprir a função social de sua profissão e, consequentemente, auxiliar na ampliação do acesso à justiça para o bem da sociedade na qual está inserido, sem que esta atividade acarretasse qualquer forma de sanção disciplinar, deveria atentar às seguintes condições:

\footnotetext{
${ }^{66}$ Tribunal de Ética e Disciplina da OAB-SP, Proc. n. E-2.392/0, São Paulo, 13 de dezembro de 2001. Ementa: Advocacia pro bono - Atividade voltada para o bem público, sem contrapartida financeira - Necessidade de regulamentação estabelecendo limites e coibindo abusos.
} 
(i) A assistência jurídica gratuita praticada pelo advogado, em regra, consiste na assessoria e consultoria jurídica, sendo a atividade jurisdicional exceção;

(ii) Não haverá qualquer forma de remuneração, sendo certo que, nas hipóteses em que haja honorários sucumbenciais, estes serão revertidos às entidades beneficiárias na forma de doação;

(iii) Os beneficiários da advocacia pro bono são pessoas jurídicas do terceiro setor, sem fins lucrativos, devidamente reconhecidas e desprovidas de recursos financeiros;

(iv) $\mathrm{O}$ advogado ou o escritório de advocacia ficará impedido, por dois anos, de prestar serviços jurídicos remunerados a empresas ou entidades coligadas à assistida, seus membros, diretores, sócios ou associados;

(v) A intenção de exercer a advocacia solidária deverá ser previamente comunicada ao Tribunal de Ética e Disciplina, esclarecendo os objetivos e alcances da atividade;

(vi) A cada seis meses deverá ser encaminhado ao referido Tribunal um relatório sobre o desenvolvimento das atividades, sendo facultado ao Tribunal de Ética requisitas eventuais esclarecimentos.

Entende-se que a principal limitação da atividade pro bono, consistente na vedação de prestar assistência jurídica a pessoas físicas, foi estabelecida em razão da $\mathrm{OAB}$ de São Paulo interpretar a Constituição Federal no sentido de que a defesa dos hipossuficientes era exclusivamente função do Estado, através da Defensoria Pública e do convênio firmado entre a Ordem e o Poder Público. ${ }^{67}$

Seguindo esse diapasão, em pesquisa realizada no site da $\mathrm{OAB}$ de São Paulo acerca da jurisprudência do Tribunal de Ética e Disciplina da referida seccional durante a vigência da Resolução Pro Bono, foram encontradas diversas decisões sobre o tema, no sentido de que a advocacia solidária deveria observar os limites impostos pela Resolução, sendo

${ }^{67}$ CANÁRIO, Pedro. Código de Ética da Advocacia liberará pro bono para pessoa física. Disponível em: <http://www.conjur.com.br/2015-jun-14/codigo-etica-advocacia-liberara-probono-pessoa-fisica>. Acesso em: 04/07/2016. 
vedada a assistência jurídica às pessoas físicas, que deveriam ser encaminhadas aos inúmeros serviços gratuitos existentes. Vejamos:

PRO BONO - ONG - ATENDIMENTO AOS NECESSITADOS ATRAVÉS DE ADVOGADO DA ENTIDADE - IMPOSSIBILIDADE - ENCAMINHAR OS NECESSITADOS DE ASSESSORIA JURÍDICA AOS INÚMEROS SERVICCOS GRATUITOS EXISTENTES. Advogado de ONG não pode atender os necessitados com base na Resolução Pro Bono. A Resolucão Pro Bono destina-se, exclusivamente, a pessoas jurídicas sem fins lucrativos. Advogar na ONG, para seus associados, pode ser interpretado como benemerência travestida de captação de clientela, concorrência desleal, práticas condenadas pelo Estatuto da Advocacia e pelo Código de Ética e Disciplina. Deverão os hipossuficientes necessitados de assessoria jurídica ser encaminhados aos inúmeros servicos gratuitos existentes, como o Convênio OAB/PGE, existente em todo o Estado de São Paulo, os Centros Acadêmicos das diversas faculdades de Direito, a Procuradoria Geral do Estado e a Defensoria Pública do Estado de São Paulo (Precedentes E-3.765/09, E 3.542/07, E3.330/06, E-2.278/00, E-2.392/01 e E-2.954/04) ${ }^{68}$ (grifei e destaquei)

\section{ADVOCACIA PRO BONO POSSIBILIDADE - RESOLUÇÃO DA SECCIONAL DE SÃO PAULO DE 19 DE AGOSTO DE 2002 - TABELA DE HONORÁRIOS - INAPLICABILIDADE NO CASO. É possível o exercício da advocacia pro bono, desde que nos termos da Resolucão de 19 de agosto de 2002, da Seccional de São Paulo da OAB. Inaplicabilidade da tabela de honorários ante a gratuidade da atividade, devendo reverter para a beneficiária eventuais honorários de sucumbência, mediante doação a ser feita pelo prestador da atividade pro bono. $\underline{\text { A advocacia gratuita }}$ para pessoas físicas carentes deve ser feita através da Assistência Judiciária ou da Defensoria Pública. ${ }^{69}$ (grifei e destaquei)}

Devido a este cenário, conforme afirma o fundador do Instituto Pro Bono, Marcos Roberto Fuchs ${ }^{70}$, em entrevista realizada, diversos advogados se mostravam receosos em praticar a advocacia pro bono ou até mesmo se

\footnotetext{
${ }^{68}$ Tribunal de Ética e Disciplina da OAB-SP, Proc. n. E-4.0852011, São Paulo, 15 de dezembro de 2011.

${ }^{69}$ Tribunal de Ética e Disciplina da OAB-SP, Proc. n. E-3.542/2007, São Paulo, 22 de novembro de 2007.

${ }^{70}$ Entrevista realizada pela autora da monografia Hannah Dias Rabe com Marcos Roberto Fuchs em 13 de abril de 2016.
} 
abstinham de praticá-la, eis que, se o fizessem, estariam passíveis de sofrer sanções disciplinares, o que poderia comprometer o regular exercício de sua profissão.

Cumpre ressaltar, entretanto, que não obstante as merecidas críticas, a Resolução Pro Bono ensejou, em nosso país, a fomentação da responsabilidade social no Direito, tendo em vista que a norma, ao permitir expressamente a advocacia pro bono, incentivou um contingente significativo de advogados voluntários a realizar a atividade, bem como contribuiu para o crescimento da demanda de serviços jurídicos gratuitos por parte das pessoas jurídicas integrantes do terceiro setor. ${ }^{71}$

Ocorre que, diante das duras críticas, os mais variados setores da comunidade jurídica pugnavam urgentemente por uma regulamentação que permitisse o livro exercício da advocacia solidária, tanto para Organizações Não Governamentais, quanto para pessoas físicas.

Nesta esteira, o ex-ministro da Justiça e renomado jurista, Miguel Reale Júnior ${ }^{72}$, defendeu a atividade pro bono em benefício de pessoas hipossuficientes, asseverando na época: "Não é uma questão de ética. O advogado que tem consciência de seu dever de atender alguém necessitado vai ser punido por falta de ética? Isso é um absurdo! ”.

Se filiando à mesma corrente de Miguel Reale Jr., a professora de Direitos Humanos e Direito Constitucional da PUC-SP, Flávia Piovesan ${ }^{73}$, em um evento sobre o assunto em questão, citou a colega Ester Laden, a qual realizou a seguinte afirmação:

“(...) a maioria dos países têm uma abordagem oposta à do Brasil, ao defender que oferecer serviços jurídicos aos necessitados é um dos maiores imperativos éticos da profissão. Aqui no Brasil vê-se de forma oposta, vê-se como antiético garantir tal atendimento, este direito a ter direitos...".

\footnotetext{
${ }^{71}$ FUCHS, Marcos Roberto. Advocacia pro bono e o novo Código de Ética e Disciplina. Revista do Advogado da AASP, n. 129, abril de 2016. Pp. 72-79.

${ }^{72}$ FUCHS, Marcos Roberto. Advocacia pro bono e o novo Código de Ética e Disciplina. Revista do Advogado da AASP, n. 129, abril de 2016. Pp. 72-79.

${ }^{73}$ CANÂRIO, Pedro. Advogados se voltam contra Resolução Pro Bono da OAB-SP. Disponível em <http://www.conjur.com.br/2013-fev-23/grandes-nomes-advocacia-voltam-resolucao-probono-oab-sp>. Acesso em: 10/10/2016.
} 
Seguindo esse diapasão, as manifestações contrárias às limitações da supracitada Resolução foram tão incisivas que o Ministério Público Federal, no dia 22 de fevereiro de 2013, por meio da Procuradoria Regional dos Direitos dos Cidadãos, em razão de um inquérito civil instaurado para analisar a questão, convocou uma audiência pública, a fim de obter conhecimento da opinião popular acercada proibição de advogados prestarem assistência jurídica e judiciária gratuita a pessoas físicas. ${ }^{74}$

Importante ressaltar que na referida audiência compareceram importantes nomes da sociedade civil e profissionais do Direito, tais como o ministro Gilmar Mendes do Supremo Tribunal Federal, a professora Flavia Piovesan, o ex-ministro da Justiça Miguel Reale Júnior e os renomados juristas Oscar Vilhena Vieira e Marcos Roberto Fuchs, diretores do Instituto Pro Bono, sendo certo que a maioria se manifestou a favor da advocacia solidária para pessoas físicas e, inclusive, admitiu já ter prestado seus serviços gratuitamente a alguém.

Por outro lado, entretanto, o então presidente da Seccional de São Paulo da Ordem dos Advogados do Brasil, Marcos da Costa, deixou de comparecer à audiência pública, sendo certo que não houve qualquer representante da $\mathrm{OAB} / \mathrm{SP}$ no evento, sob o argumento de que, como o tema trata sobre a regulamentação da profissão, o assunto seria de competência do Conselho Federal da OAB, a qual já estaria analisando o assunto, razão pela qual não poderia exprimir suas opiniões - em nome da seccional paulista - na audiência realizada.

Imperioso se faz destacar os posicionamentos adotados por alguns notáveis juristas e representantes da sociedade jurídica e civil durante o evento, a fim de que seja possível demonstrar o panorama geral de descontentamento que reinava à época em relação à Resolução Pro Bono, vigente há onze anos.

${ }^{74}$ FUCHS, Marcos Roberto. Advocacia pro bono e o novo Código de Ética e Disciplina. Revista do Advogado da AASP, n. 129, abril de 2016. Pp. 72-79. 
Primeiramente, asseverou o fundador do Instituo Pro Bono, Marcos Fuchs, que a advocacia solidária se traduz em uma questão de cidadania, dignidade e de direitos humanos, tendo em vista que, conforme dados do INGE, $83 \%$ da população brasileira não possui condições financeiras de arcar com os custos de honorários advocatícios, sendo essa prestação de serviços ainda um privilégio destinado apenas a uma pequena parcela da população.

Seguindo o supracitado entendimento, a professora Flavia Piovesan ressaltou a importância da advocacia pro bono, eis que esta atividade amplia o acesso à justiça e diminui as desigualdades sociais existentes em nosso país, colaborando para a transformação de uma justiça mais eficiente, democrática e efetiva, a qual encontra-se inserida, atualmente, num contexto de larga exclusão.

Ainda em seu discurso, a professora de Direito Constitucional salientou que o exercício da advocacia solidária contribui para resgatar a função social da advocacia originada com Luis Gama e Rui Barbosa, bem como efetivar os direitos humanos.

Por sua vez, o ministro Gilmar Mendes do Supremo Tribunal Federal, chamou atenção ao fato de que, devido à nossa cultura litigiosa, o Estado Social Brasileiro se concretiza através da judicialização, ou seja, a atuação da Justiça e o amplo acesso a ela consistem nos pilares do Estado Democrático de Direito, eis que viabilizam os direitos mais fundamentais, como o direito à vida e à liberdade.

Acrescentou o ministro, ainda, que se faz urgente extinguir a denominada hermenêutica de interesse, na qual a mentalidade corporativa enseja interpretações viciadas, visando beneficiar determinadas corporações e não o bem comum.

Ressalte-se, por oportuno, que ao realizar a supramencionada crítica, Gilmar Mendes claramente se referia à seccional paulista da Ordem dos Advogados, que se posicionava contrariamente à prestação jurídica gratuita destinada a pessoas físicas, tendo em vista o descomunal convênio firmado 
com o Poder Público, o qual visava os interesses dos 40 mil advogados nele inscritos, na época, e não os interesses sociais.

Representando a Defensoria Pública do Estado de São Paulo e a Associação Nacional dos Defensores Públicos, encontravam-se presentes na audiência os defensores públicos Renato Campos Vito e Antonio Mafiezoli, respectivamente, os quais declararam em uníssono que a referida entidade não possui qualquer objeção quanto à prática da advocacia pro bono, esclarecendo que jamais arrogaram o monopólio do tema, pois admitem que a Defensoria precisa ser reforçada diante da inacessibilidade jurídica existente em nosso país.

Ambos criticaram veementemente a postura da OAB de São Paulo quanto à limitação da advocacia pro bono em benefício apenas das pessoas jurídicas integrantes do terceiro setor, ressaltando, inclusive, que a referida entidade pressionava os escritórios modelos das faculdades e as entidades de direitos humanos para que não realizassem qualquer parceria com a Defensoria Pública. ${ }^{75}$

Imperioso salientar que a repercussão da audiência pública no meio jurídico foi tão significativa, no sentido de demonstrar a insatisfação por parte de diversos juristas renomados com a Resolução Pro Bono, que a Procuradoria Regional dos Direitos do Cidadão em São Paulo, após a realização do evento, recomendou ao então presidente do Conselho Federal da $\mathrm{OAB}$ que reformulasse as normas acerca do tema, a fim de que fosse permitida a atividade pro bono em favor de pessoas físicas, sem que houvesse qualquer responsabilização ético-disciplinar para os advogados solidários. $^{76}$

Assim sendo, em menos de quatro meses após a celebração da audiência pública, no dia 17 de junho de 2013, o Conselho Federal da OAB,

\footnotetext{
${ }^{75}$ CANÁRIO, Pedro. Advogados se voltam contra Resolução Pro Bono da OAB-SP. Disponível em $<$ http://www.conjur.com.br/2013-fev-23/grandes-nomes-advocacia-voltam-resolucao-pro-bonooab-sp>. Acesso em: 10/10/2016.

${ }^{76}$ JURÍDICO, Consultor. Procuradoria pede que OAB-SP aprove pro bono. Disponível em: $<$ http://www.conjur.com.br/2013-mar-18/procuradoria-republica-aprovacao-advocacia-pro-bonosao-paulo>. Acesso em: 09/06/2016.
} 
por meio de liminar dada pelo relator do processo, Luiz Flávio Borges D’Urso, suspendeu em todo o país as regras limitativas da atividade pro bono até que seja elaborada norma específica regulamentando o tema pela entidade federal.

Em seu despacho, o relator D'Urso fundamentou sua decisão baseando-se na relevância da prática pro bono tanto para a advocacia, quanto para a sociedade, bem como ante a ausência de um tratamento nacional para o referido instituto, fato que acarretou em diversos mal entendidos, tendo em vista que algumas seccionais editaram normas próprias.

Ainda, o relator ressaltou que a atividade pro bono não consiste apenas na prestação jurídica gratuita por parte de um advogado autônomo em favor de algumas pessoas, mas sim em um verdadeiro sistema, razão pela qual necessita pautar-se por regras bem delimitadas, a fim de evitar dúvidas e confusões. ${ }^{77}$

Cumpre ressaltar, por oportuno, que de acordo com Sérgio Rodas ${ }^{78}$, após o Conselho Federal da Ordem dos Advogados do Brasil ter homologado a decisão supramencionada, o então Presidente determinou a instauração de uma comissão específica sobre o tema, cuja função primordial tratava-se de, por meio de debates, elaborar um regramento nacional acerca da matéria.

Destarte, os dois anos seguintes à suspensão da Resolução foram dedicados a campanhas e projetos acerca do tema.

Seguindo esse diapasão, tendo em vista a tramitação do novo Código de Ética e Disciplina no Conselho Federal da OAB, o ano de 2015 foi iniciado com diversos debates, os quais visavam a inserção de normas capazes de regular a advocacia pro bono no referido diploma, pacificando

\footnotetext{
${ }^{77} \mathrm{OAB}$, Conselho Federal da. OAB suspende a limitação de advocacia pro-bono no país. Disponível em: <http://www.oab.org.br/noticia/25774/oab-suspende-a-limitacao-de-advocaciapro-bono-no-pais>. Acesso em: 05/06/2016.

${ }^{78}$ RODAS, Sérgio. Pro bono é menos desenvolvido no Brasil do que no resto da América Latina. Disponível em: <http://www.conjur.com.br/2014-dez-13/pro-bono-desenvolvido-brasil-americalatina\#top>. Acesso em: 13 de julho de 016.
} 
de uma vez por todas a controvérsia acerca do tema que perdurava por mais de uma década.

Por fim, destaca Marcos Fuchs ${ }^{79}$, em 14 de junho de 2015, o Conselho Federal da $\mathrm{OAB}$ se reuniu em caráter extraordinário, a fim de deliberar sobre o novo Código de Ética e Disciplina, sendo certo que um dos temas votados e aprovados naquela sessão se referia à advocacia pro bono, cuja previsão finalmente se deu em capítulo próprio, no artigo 30.

Importante ressaltar, por oportuno, que na supracitada sessão foi determinada a elaboração de um provimento - Ato Provimento n ${ }^{0}$ 166/2015 -, cuja função é fundamentar e dirimir eventuais questões acerca da prática da advocacia solidária.

Sobre esses acontecimentos, Miguel Reale Junior ${ }^{80}$ observou que como era de se esperar, a novidade prevista no novo Código de Ética e Disciplina foi recebida com entusiasmo e celebração pela comunidade jurídica, eis que a prestação voluntária e gratuita de serviços jurídicos era, agora, indiscutivelmente uma atuação ética, eliminando qualquer dúvida acerca desta questão.

No mesmo sentido, Andrey Cavalcante ${ }^{81}$ ressalta a contribuição deum dos maiores fomentadores da advocacia pro bono no Brasil, Marcos Fuchs, para quem a inclusão do tema ora exarado no referido diploma ético traduz a ideia de que a $\mathrm{OAB}$ está efetivamente preocupada com a responsabilidade social do advogado, incentivando-a.

Acrescenta, ainda, Adriana $\operatorname{Aguiar}^{82}$ que esse apoio à atividade pro bono ajudará a construir um Estado de direito mais justo e igualitário, beneficiando, em última análise, a democracia.

\footnotetext{
${ }^{79}$ FUCHS, Marcos Roberto. Advocacia pro bono e o novo Código de Ética e Disciplina. Revista do Advogado da AASP, n. 129, abril de 2016. Pp. 72-79.

${ }^{80}$ JÚNIOR, Miguel Reale. Advocacia pro bono: ocupação feliz. Revista do Advogado da AASP, $\mathrm{n}$. 129, abril de 2016. Pp. 105-109.

${ }^{81}$ CAVALCANTE, Andrey. Advocacia Pro Bono: A OAB em favor do cidadão. Disponível em: <http://www.portalrondonia.com/noticias/35957.htm>. Acesso em: 22/06/2016.

${ }^{82}$ AGUIAR, Adriana. Advocacia gratuita é regulamentada pela OAB. Disponível em: <http://www.ftiapr.org.br/noticias/noticias-juridicas/896-advocacia-gratuita-e-regulamentada-pelaoab.html>. Acesso em: 05/06/2016.
} 
Autores que se debruçam sobre o estudo da ética profissional, a exemplo de Humberto Rego e Victor Matos $^{83}$, também comemoram e afirmam que é sabido que, embora a advocacia solidária sempre houvesse sido praticada em nosso país, lhe carecia de uma estrutura jurídica que contivesse um regramento específico na esfera ético-disciplinar, a fim de dar-lhe maior organicidade.

Por todo o exposto neste capítulo, extrai-se que a advocacia pro bono, apesar de ser uma das mais antigas práticas judiciais, percorreu um longo e árduo caminho até ser devidamente regulamentada pelo Código de Ética e Disciplina da $\mathrm{OAB}$, atravessando diversos obstáculos que impediam o seu livre exercício.

Contudo, as desigualdades alarmantes presentes em nosso país, combinadas com o acesso à justiça limitado apenas às classes mais privilegiadas - que são a minoria, no caso brasileiro -, e a crescente ineficiência do Estado em prover assistência jurídica gratuita a todos os que dela necessitam, serviram de combustível para a incansável luta, inclusive por parte dos mais renomados juristas, pela permissão plena do exercício da advocacia pro bono, tanto em prol de pessoas jurídicas, quanto de pessoas físicas que não possuem recursos para arcar com as custas processuais e os honorários advocatícios.

\subsection{Advocacia pro bono x Advocacia pública gratuita}

\subsubsection{Qual a diferença entre a advocacia pública gratuita e a advocacia pro bono?}

Questão que merece especial reflexão trata-se da diferença entre a assistência jurídica pública gratuita e a advocacia pro bono, a fim de que

\footnotetext{
${ }^{83}$ RÊGO, Humberto Henrique Costa Fernandes do; MATOS, Victor dos Santos Maia. Ética profissional e advocacia pro bono: o papel do advogado na conquista da cidadania. Revista do Advogado da AASP, n. 129, abril de 2016. Pp. 47-53.
} 
seja possível saber se ambos os institutos são complementares ou excludentes, como melhor será analisado em item próprio.

Cumpre relembrar, inicialmente, que o Brasil possui uma das sociedades mais desiguais do mundo, onde a miséria, o analfabetismo, a exclusão social e a violência infelizmente são consideradas a regra ao invés da exceção.

Diante desse cenário, a Constituição Federal determinou, em seu artigo $5^{\circ}$, inciso LXXIV, ser dever irrenunciável do Poder Público prestar assistência jurídica integral e gratuita àqueles que não possuem recursos financeiros para arcar com os honorários de um advogado, devendo o Estado custear e oferecer esse serviço.

Insta salientar que a Carta Magna, ao determinar em seu artigo 134 a implementação das Defensorias Públicas em todos os Estados, na forma do artigo $5^{\circ}$, inciso LXXIV, incumbiu à referida instituição o papel de órgão principal na prestação de assistência jurídica gratuita pelo Poder Público. ${ }^{84}$

Importante ressaltar, por oportuno, que conforme se depreende da leitura do artigo 134 da Constituição Federal, a denominada "assistência jurídica" transcende à simples defesa, judicial ou extrajudicial, dos direitos individuais e coletivos dos hipossuficientes, eis que compreende também a orientação jurídica, bem como a promoção dos direitos humanos.

Assim sendo, pode-se afirmar que a assistência jurídica gratuita e integral, quando subsidiada pelo Estado, consiste na prestação de uma advocacia pública gratuita.

Ocorre que, conforme dito, a Defensoria Pública consiste no órgão principal de prestação de assistência jurídica gratuita, porém não no único. Ao lado dessa instituição, há outras modalidades de advocacia pública gratuita destinadas a patrocinar os interesses dos economicamente desfavorecidos, quais sejam: (Flavia Regina de Souza 2001)

(i) Ministério Público, em casos excepcionais;

\footnotetext{
${ }^{84}$ PLANALTO. Constituição da República Federativa do Brasil de 1988. Disponibilizada em: 〈http://www.planalto.gov.br/ccivil_03/constituicao/constituicaocompilado.htm〉. Acesso em: 04/05/2016.
} 
(ii) Advogados Dativos

Imperioso esclarecer, entretanto, que o referido instituto difere da advocacia pro bono, a qual, segundo Fábio Comparato citado por Flávia Oliveira ${ }^{85}$, é definida como uma "advocacia privada de interesse público", eis que é exercida por advogados particulares de forma gratuita e solidária em prol do bem comum, visando a ampliação da cidadania através do pleno acesso à justiça.

Seguindo esse diapasão, as duas modalidades de assistência jurídica gratuita não se confundem, sendo certo que a atividade pro bono é voluntária e encontra-se no âmbito privado, sem que haja qualquer subsídio por parte do Poder Público.

A advocacia pública gratuita, por sua vez, é obrigatória, eis que consiste num dever irrenunciável e intransferível do Estado, bem como os profissionais que prestam a assistência jurídica pública são remunerados pelo Estado.

Corroborando o entendimento de que os supracitados institutos são diferentes, o art. $3^{\circ}$ do Ato Provimento $n^{\circ} 166 / 2015$, cujo objetivo consiste em complementar a regulamentação da atividade pro bono disposta no Código de Ética e Disciplina, informa que as normas referentes à advocacia solidária não se aplicam à assistência jurídica gratuita realizada pela Defensoria Pública ou decorrente de eventuais convênios celebrados pela Ordem dos Advogados do Brasil. ${ }^{86}$

Por todo o exposto, indiscutível que a assistência jurídica pública gratuita possui natureza diversa da advocacia pro bono, sendo certo que a primeira é um dever do Estado e, por isso, subsidiada por este, e a segunda consiste em uma iniciativa privada, voluntária e gratuita.

\footnotetext{
${ }^{85}$ OLIVEIRA, Flávia Regina de Souza, et al. Advocacia Pro Bono: guia prático para escritórios . Disponível em: <http://www.cesa.org.br/arquivos/com_advcom_cartilha.pdf>. Acesso: 23/07/2016.

${ }^{86}$ Ato Provimento no 166/2015. Disponível em: < http://www.oab.org.br/noticia/29076/oab-editaprovimento-que-regulamenta-a-advocacia-pro-bono>
} 


\subsubsection{Advogados dativos $x$ advogados solidários}

A fim de esclarecer eventuais dúvidas acerca da relação entre a advocacia pro bono e a assistência jurídica prestada por advogados dativos, eis que muitos operadores do Direito confundem essas duas práticas, mister se faz ressaltar as diferenças existentes entre os referidos institutos.

Decerto, o Estado possui o dever constitucional de proporcionar assistência jurídica gratuita e integral aos hipossuficientes, preferencialmente por meio da Defensoria Pública.

Ocorre que, conforme anteriormente estudado, ainda que a Defensoria Pública do Estado do Rio de Janeiro seja uma das mais avançadas do Brasil, essa instituição ainda carece de estrutura humana e material, a fim de que seja capaz de atender a imensa demanda existente. ${ }^{87}$

Por outro lado, o Código de Processo Penal, em seu artigo 261, parágrafo único, dispõe que nenhum acusado será processado ou julgado sem defensor, bem como a Constituição da República assegura, em seu artigo $5^{\circ}$, inciso LV, o direito ao contraditório e à ampla defesa, estando a defesa técnica inserida neste último como um direito irrenunciável.

Assim sendo, conforme o artigo 263 do Código de Processo Penal, na hipótese do acusado não possuir um advogado constituído nos autos, é facultado ao Magistrado nomear defensor para realizar o ato processual. Preferencialmente será nomeado um Defensor Público, porém, na falta desse, será nomeado advogado dativo para fazê-lo. ${ }^{88}$

Destarte, o advogado dativo possui funções idênticas ao do advogado ou Defensor Público que patrocina a causa por completo, quais sejam: auxiliar a parte durante a audiência, seja de conciliação ou de instrução e

\footnotetext{
${ }^{87}$ VIEIRA, Oscar Vilhena. Três teses equivocadas sobre "pro bono". Disponível em: <http://www1.folha.uol.com.br/fsp/opiniao/fz0903200610.htm >. Acesso em: 05/06/2016.

${ }^{88}$ PLANALTO. Código de Processo Penal. Disponível em: 〈http://www.planalto.gov.br/ccivil_03/decreto-lei/Del3689Compilado.htm〉. Acesso em $22 / 10 / 2016$
} 
julgamento, bem como acompanhar o trâmite processual tanto da fase de conhecimento, quanto da de execução. ${ }^{89}$

Insta salientar que a atuação dos advogados dativos não se restringe apenas à área criminal, mas sim a todas aquelas em que a Defensoria Pública ainda não é suficiente para, sozinha, atender a todas as pessoas hipossuficientes.

A fim de corroborar o acima exposto, observa-se a seguinte notícia publicada pelo Poder Judiciário do Estado do Rio de Janeiro em janeiro do corrente ano, a qual prevê a abertura de vagas para atuação de advogados dativos no Juizado Especial Cível de Friburgo:

"O Juizado Especial Cível de Nova Friburgo, na região serrana do Rio de Janeiro, está com vagas abertas para a atuação em regime voluntário de advogados dativos.

A atuação desses advogados começará em fevereiro, em dia ainda a ser agendado. Para participar, os interessados deverão dispor de um dia a ser dedicado ao plantão, em sala reservada especialmente aos dativos. Dependendo do número de selecionados, os plantões poderão ser fracionados.

O juiz Eric Scapim Cunha Brandão, do JEC, informa aos advogados que deverão entregar seus currículos no gabinete do juizado, na Av. Euterpe Friburguense 201, primeiro andar, Centro de Nova Friburgo". ${ }^{5}$

Importante ressaltar que não obstante a supracitada notícia adote a expressão "em regime voluntário", entende-se que é devido o pagamento dos honorários advocatícios, pelo Estado, em contraprestação à atuação do advogado dativo. É o que determina o artigo $22, \S 1^{\circ}$ da Lei $n^{\circ} 8906 / 94-$ Estatuto da $\mathrm{OAB}$, abaixo transcrito:

“Art. 22. A prestação de serviço profissional assegura aos inscritos na OAB o direito aos honorários convencionados, aos fixados por arbitramento judicial e aos de sucumbência.

$\S 1^{\circ} \mathrm{O}$ advogado, quando indicado para patrocinar causa de juridicamente necessitado, no caso de impossibilidade da Defensoria Pública no local da prestação de serviço, tem direito aos honorários fixados pelo juiz, segundo tabela organizada pelo Conselho Seccional da OAB, e pagos pelo Estado".

\footnotetext{
${ }^{89}$ JANEIRO, Poder Judiciário do Estado do Rio de. Juizado Especial Cível de Nova Friburgo tem inscrição para advogado dativo. Data da publicação: 27/01/2016. Disponível em: <http://www.tjrj.jus.br/web/guest/home/-/noticias/visualizar/29103?p_p_state=maximized $>$. Acesso em 07/10/2016.
} 
Insta salientar que o Tribunal de Justiça do Estado do Rio de Janeiro e o Superior Tribunal de Justiça possuem jurisprudência consolidada no sentido de que, quando os advogados dativos patrocinarem causas de hipossuficientes na falta da Defensoria Pública, o Estado deverá arcar com os honorários advocatícios, ainda que a atuação do profissional se restrinja a apenas um ato processual. Veja-se:

Apelação cível. Cobranca de honorários advocatícios. Advogado dativo nomeado pelo magistrado. Procedência do pedido. Recurso do estado pretendendo a improcedência do pedido ou a redução do valor arbitrado. Atuação como defensor público. Art. $22, \$ 1 .^{\circ}$, da lei $\mathbf{n}^{\circ}{ }^{\circ}$ 8.904/94. Honorários devidos de acordo com a tabela da oab. Desprovimento do recurso. ${ }^{90}$

Apelação cível. Embargos à execução. Fixacão de honorários em favor de defensor dativo em sentença criminal. Direito do advogadona forma do art. 22 caput e $\$ 1^{\circ}$ Lei 8906/94. Título executivo extrajudicial à inteligência do art. 24 Lei 8906/94 e art. 585, VI CPC. Alegação de iliquidez do título e de que o Estado executado não teria sido notificado da formulação do título. Desnecessidade da notificação. Ampla defesa garantida na forma do art. 745 e inciso V CPC. Embargante que deve ser intimado pelo Juízo para emendar a inicial. Inteligência do art. 616 c/c 614 CPC. Aplicação dos princípios de celeridade e economia processual. Precedentes STJ. Sentença que se reforma. Declaração de nulidade do título que se afasta. Questões relativas aos embargos que restam prejudicadas. Recurso provido na forma do art. $\left.557 \S 1^{\mathrm{a}} \mathrm{A}\right) \mathrm{CPC} .{ }^{91}$

APELAÇÃO CÍVEL. EMBARGOS DE DEVEDOR. EXECUCÃO DE HONORÁRIOS ADVOCATÍCIOS POR ATUACÃO COMO ADVOGADO DATIVO EM ACÃO PENAL, EM LOCALIDADE ONDE NÃO HAVIA ÓRGÃO DA DEFENSORIA PÚBLICA. TÍTULO LÍQUIDO, CERTO E EXIGÍVEL. INTELIGÊNCIA DOS ARTIGOS 22 E 24 DA LEI No 8906/94 E DO ARTIGO 585, VI, DO CPC/73. EXCESSO DE EXECUÇÃO NÃO COMPROVADO. FIXACÃO DA VERBA HONORÁRIA DE ACORDO COM O TRABALHO REALIZADO PELO CAUSÍDICO E DA TABELA DE HONORÁRIOS DA OAB VIGENTE À ÉPOCA. RECURSO DESPROVIDO. ${ }^{92}$

EMENTA CONSTITUCIONAL. COMPETÊNCIA. JUSTIÇA COMUM E JUSTIÇA DO TRABALHO. ACÃO DE COBRANCA DE HONORÁRIOS ADVOCATÍCIOS ARBITRADOS EM FAVOR DE ADVOGADO DATIVO

\footnotetext{
${ }^{90}$ TJRJ, Apelação n. 0011378-55.2009.8.19.0026, Des. Rel. Norma Suely Fonseca Quintes, Oitava Câmara Cível, Rio de Janeiro, Data de Julgamento: 30/09/2013.

${ }^{91}$ TJRJ, Apelação n. 0190679-32.2012.8.19.0001,Des. Rel. Cristina Tereza Gaulia, Quinta Câmara Cível, Rio de Janeiro,Data de Julgamento: 27/10/2014.

${ }^{92}$ TJRJ, Apelação n.0000915-14.2012.8.19.0070, Des. Jacqueline Lima Montenegro, Décima Quinta Câmara Cível, Rio de Janeiro, Data De Julgamento: 28/06/2016.
} 
NOMEADO EM ACÕES PROCESSADAS NA JUSTICA COMUM ESTADUAL. EXISTÊNCIA DE REPERCUSSÃO GERAL.

Agravo regimental no agravo em recurso especial. Violação aos arts. 458, 463 e 535 do cpc/73. Inexistência.defensor dativo. Honorários advocatícios. Responsabilidade pelo pagamento. Estado. Defensoria Pública inexistente ou precária. Incidência das súmulas 83 e 7 do STJ.

1. Não houve ofensa aos arts. 458,463 e 535 do CPC/73, na medida em que o Tribunal de origem dirimiu, fundamentadamente, as questões que lhe foram submetidas, apreciando integralmente a controvérsia posta nos presentes autos, não se podendo, ademais, confundir julgamento desfavorável ao interesse da parte com negativa ou ausência de prestação jurisdicional.

2. O recurso especial não impugnou fundamentos basilares do acórdão recorrido, esbarrando, pois, no obstáculo da Súmula 283/STF.

3. A alteração do julgado, tal como colocada a questão nas razões recursais, demandaria, necessariamente, novo exame do acervo fático-probatório constante dos autos, providência vedada em recurso especial, conforme o óbice previsto na Súmula 7/STJ.

4. "A orientacão jurisprudencial do STJ é no sentido de são devidos honoráriosde advogado ao curador especial, devendo ser custeado pelo Estado, haja vista que o advogado dativo não pode ser compelido a trabalhar gratuitamente em face da carência ou ausência de Defensoria Pública na região"

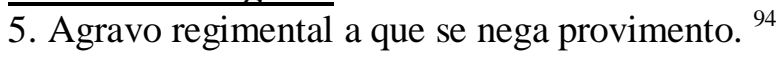

Seguindo esse diapasão, conclui-se que a atividade dos advogados dativos consiste em uma advocacia pública gratuita, bem como uma prática remunerada, eis que o Estado custeia os honorários advocatícios desses profissionais.

Diferentemente ocorre com a advocacia pro bono, a qual consiste em uma advocacia privada de interesse público, tendo em vista não ser subsidiada pelo Poder Público.

Em verdade, conforme ressalta Marcos Fuchs, a advocacia solidária, por ser uma atividade voluntária e gratuita, é isenta de qualquer forma de remuneração, ainda que indireta. ${ }^{95}$

Pelo acima exposto, conclui-se que os advogados dativos, ao contrário dos que realizam o pro bono, não prestam serviços jurídicos de

\footnotetext{
${ }^{93}$ STJ, Repercussão Geral No Recurso Extraordinário n. 607520 RG / MG, Min. Rel. Dias Toffoli, Tribunal Pleno, Brasília, Data de Julgamento: 09/09/2010.

${ }^{94}$ STJ, AgRg no AREsp 729318 / PE, Ministro Relator Sérgio Kukina,Primeira Turma, Brasília, Data do Julgamento: 17/05/2016.

${ }^{95}$ Entrevista realizada pela autora da monografia por Hannah Rabe com Marcos Roberto Fuchs, diretor do Instituto Pro Bono, em 07/11/2016.
} 
forma gratuita e voluntária, tendo em vista que são remunerados, razão pela qual sua assistência jurídica jamais poderia ser considerada pro bono. ${ }^{96}$

\subsubsection{O papel da Defensoria Pública no contexto da assistência jurídica gratuita}

Por meio de uma análise sistemática da Constituição Federal, a partir da leitura do artigo $5^{\circ}$, inciso LXXIV, combinado com o artigo 134, extraise que o Brasil adotou um sistema de serviço público essencial, gratuito e profissional, no qual a Defensoria Pública figura como principal instrumento de prestação de assistência jurídica gratuita e integral aos hipossuficientes. ${ }^{97}$

Destarte, a Defensoria Pública do Estado do Rio de Janeiro assim se classifica em seu site:

"Somos uma instituição pública cuja função é oferecer, de forma integral e gratuita, assistência e orientação jurídica aos cidadãos que não possuem condições financeiras de pagar as despesas destes serviços". 98

Insta salientar que o supracitado órgão atua através dos defensores públicos, isto é, indivíduos bacharelados em Direito que, após três anos de prática forense e admissão em rigoroso concurso de provas e títulos, adquirem habilitação para exercer o cargo, atuando no primeiro e no segundo graus de jurisdição, com titularidade e atribuições específicas em razão da matéria. ${ }^{99}$

Imperioso ressaltar que os servidores públicos em questão, sejam eles federais ou estaduais, possuem deveres de observância obrigatória,

\footnotetext{
${ }^{96} \mathrm{BONO}$, Instituto Pro. Convênio entre OAB e Defensoria Pública não é caracterizado como advocacia pro bono e pode ser celebrado com qualquer entidade. Disponível em: $<\mathrm{http}: / / \mathrm{www}$.probono.org.br/convenio-entre-oab-e-defensoria-publica-nao-e-caracterizado-comoadvocacia-pro-bono-e-pode-ser-celebrado-com-qualquer-entidade>. Acesso em: 22/06/2016.

${ }^{97}$ NASCIMENTO, Marcos Henrique Caetano do. Advocacia pro bono e a democratização do acesso à justiça. Revista Jurídica Consulex, ano XVII, n. 398, 15 de ago de 2013. Pp. 36-37.

${ }^{98}$ JANEIRO, Defensoria Pública do Estado do Rio de. Página: "O que é? Pra quem é?". Disponível em: <http://www.defensoria.rj.def.br/Institucional/o-que-e-defensoria〉. Acesso em 07/10/2016.

${ }^{99}$ Defensoria Pública do Estado do Rio de Janeiro. Página: “O que é? Pra quem é??. Disponível em: <http://www.defensoria.rj.def.br/Institucional/o-que-e-defensoria〉. Acesso em: 07/06/2016.
} 
elucidados nos artigos 45 e 129 da Lei Complementar 80/94, respectivamente, tais com: "atender ao expediente forense e participar dos atos judiciais, quando for obrigatória a sua presença", bem como "interpor os recursos cabíveis para qualquer instância ou Tribunal e promover revisão criminal, sempre que encontrar fundamentos na lei, jurisprudência ou prova dos autos", sob pena de cometer infração disciplinar. ${ }^{100}$

Paralelamente aos deveres supramencionados, os membros da Defensoria Pública, segundo disposição do artigo 130 da referida lei, encontram-se proibidos de exercer qualquer outra atividade remunerada, sendo imprescindível a dedicação exclusiva para atuação no cargo.

Ademais, os referidos servidores públicos gozam de determinadas prerrogativas inerentes à sua profissão, quais sejam: prazos processuais em dobro, requisição gratuita de documentos, intimação pessoal com vista dos autos, titularidade para propor ação coletiva e independência funcional. ${ }^{101}$

Assim sendo, pelo exposto, não obstante tanto os defensores públicos, quanto os advogados solidários prestarem assistência jurídica gratuita a quem necessita, indubitável que os referidos profissionais não se assemelham, tendo em vista que somente o servidor público possui os supramencionados deveres, prerrogativas e remuneração estatal.

Insta salientar que tampouco os defensores públicos se confundem com os advogados dativos, uma vez que esses não se dedicam exclusivamente à atividade, não possuem vínculo empregatício com o Estado, não patrocinam a causa por inteiro, além de que sua atuação é facultativa, podendo negar-se a realizar o ato.

Após os supracitados esclarecimentos, conclui-se que a Defensoria Pública, por previsão constitucional, é o principal órgão de prestação de assistência jurídica gratuita aos hipossuficientes.

\footnotetext{
100 PLANALTO. Lei Complementar n. 80, de 12 de janeiro de 1994. Brasília. Disponível em: <http://www.planalto.gov.br/ccivil_03/leis/LCP/Lcp80.htm>. Acesso em: 08/10/2016.

${ }^{101}$ CASTRO, André Luís Machado de e Rafael Morais Português de Souza. Retrocesso e Corporativismo. Disponível em: <http://wwwl.folha.uol.com.br/fsp/opiniao/61956-retrocesso-ecorporativismo.shtml>. Acesso em: 16/10/2016.
} 
Resta saber, no momento, o posicionamento dessa instituição acerca da implementação da advocacia pro bono no Brasil, tendo em vista que, conforme salienta o Procurador-Geral da OAB, Fábio Nogueira, existia um debate acerca da compatibilização entre a advocacia solidária, enquanto um verdadeiro sistema, e a previsão constitucional das Defensorias Públicas. ${ }^{102}$

Durante a audiência pública realizada em São Paulo sobre a advocacia pro bono, Antonio José Maffezoli Leite, presidente da Associação Nacional dos Defensores Públicos, declarou expressamente, em nome dos então 5.300 defensores públicos, que esses não são contra a advocacia solidária. Assim asseverou em seu discurso:

“(...) nós nos colocamos desde sempre ao lado da Advocacia Solidária, do Instituto Pro Bono, do IDDD e da Conectas, que têm sido parceiros importantes da Defensoria para entender que uma coisa é o dever do Estado de prestar assistência jurídica e outra coisa é a possibilidade de advogados, assistentes sociais, carpinteiros etc contribuírem para uma atividade mais justa". ${ }^{103}$

No mesmo sentido, Pedro Canário ${ }^{104}$, destaca que Renato Campos de Vito, representante da Defensora Pública Geral do Estado de São Paulo, ressaltou que a instituição "nunca se arrogou e nunca irá se arrogar no monopólio do tema", acrescentando que, diante de uma política de prestação de assistência jurídica gratuita estatal insuficiente, a Defensoria necessita ser reforçada.

Pelo acima exposto, extrai-se que o órgão em questão não se opõe à institucionalização da advocacia pro bono, sendo certo que, inclusive, admite ser necessária e apoia iniciativas para sua difusão na sociedade brasileira.

\footnotetext{
${ }^{102}$ Entrevista realizada pela autora da monografia Hannah Rabe com Fabio Nogueira, Procurador Geral da OAB-RJ, em 27/10/2016.

${ }^{103}$ CANÁRIO, Pedro. Advogados se voltam contra Resolução Pro Bono da OAB-SP. Disponível em <http://www.conjur.com.br/2013-fev-23/grandes-nomes-advocacia-voltam-resolucao-probono-oab-sp>. Acesso em: 10/10/2016.

${ }^{104}$ CANÁRIO, Pedro. Advogados se voltam contra Resolução Pro Bono da OAB-SP. Disponível em <http://www.conjur.com.br/2013-fev-23/grandes-nomes-advocacia-voltam-resolucao-probono-oab-sp>. Acesso em: 10/10/2016. >. Acesso em: 10/10/2016.
} 
Todavia, conforme ressaltado pelo Defensor Público do Estado do Rio de Janeiro, Rogério Rabe, em entrevista ${ }^{105}$, a Defensoria Pública combate veementemente a utilização de recursos públicos para financiar a prestação de assistência jurídica gratuita realizada por advogados particulares, como é o caso dos dativos. ${ }^{106}$

Entretanto, o supracitado servidor público reconhece que há áreas do Direito em que a Defensoria Pública ainda não é integralmente estruturada, como é o caso da Justiça Federal e dos Juizados Especiais Cíveis, razão pela qual a atuação dos advogados dativos é medida necessária, porém temporária, devendo o Estado reunir esforços para implementar de forma efetiva a referida instituição.

\subsubsection{Advocacia pro bono e advocacia pública gratuita: se excluem ou se complementam?}

Conforme anteriormente explanado, a advocacia pro bono possui natureza totalmente diversa da assistência jurídica gratuita pública. Cabe agora, portanto, analisar se esses dois institutos podem existir em harmonia ou se são excludentes entre si, havendo espaço apenas para uma dessas modalidades.

Insta salientar, primeiramente, que há quem diga que a assistência jurídica gratuita deve ser prestada única e exclusivamente pelo Estado, diante da determinação constitucional prevista nos artigos $5^{\circ}$, inciso LXXIV, e 134 da Carta Magna, não podendo a advocacia pro bono substituir a advocacia pública gratuita. ${ }^{107}$

Entretanto, como se verá a seguir, para a maioria dos juristas e estudiosos do tema, a advocacia solidária não possui o objetivo de prestar serviços jurídicos gratuitos aos hipossuficientes, a fim de usurpar a

\footnotetext{
${ }^{105}$ Entrevista realizada pela autora da monografia Hannah Rabe com Rogério Rabe, Defensor Público de Classe Especial do Estado do Rio de Janeiro, em: 20/10/2016.

${ }^{106}$ Entrevista realizada pela autora da monografia Hannah Rabe com Rogério Rabe, Defensor Público de Classe Especial do Estado do Rio de Janeiro, em: 20/10/2016.

${ }^{107}$ VIEIRA, Oscar Vilhena. Três teses equivocadas sobre "pro bono". Disponível em: <http://www1.folha.uol.com.br/fsp/opiniao/fz0903200610.htm >. Acesso em: 05/06/2016.
} 
competência da Defensoria Pública, uma vez que esta obrigação é intransferível, cabendo necessariamente ao ente público.

Ocorre que, segundo Flávia Piovesan e Miguel Reale Júnior, apesar de imprescindível, a obrigação estatal de prestar assistência jurídica aos necessitados não pode ser entendida como um monopólio do Poder Público, eis que, de acordo com uma interpretação sistemática sob a ótica valorativa e principiológica, considerando a indispensabilidade do advogado prevista no artigo 133 da Constituição Federal, extrai-se que não há que se falar em exclusividade, pelo Estado, acerca do tema. ${ }^{108}$

Assim sendo, a atividade pro bono deve contribuir de modo subsidiário ao Poder Público sempre quando este não for capaz de atender as demandas existentes, visando ampliar o acesso à Justiça, bem como colaborar para o melhor uso dos recursos públicos. ${ }^{109}$

Seguindo esse diapasão, o secretário da Reforma do Judiciário, Flávio Crocce Caetano, na audiência pública realizada em São Paulo a fím de debater as questões pertinentes à advocacia pro bono, ressaltou a importância da criação de uma Rede de Proteção Judicial, o que ampliaria o acesso ao Poder Judiciário e ao Sistema de Acesso à Justiça a toda a população.

Ressalte-se, por oportuno, que Flávio Crocce Caetano assim conceituou a denominada Rede de Proteção Judicial:

“(...) uma rede de assistência popular e jurídica que tenha coordenação na Defensoria Pública, em que estejam presentes a Advocacia Dativa, a Advocacia pro Bono, Núcleos de Práticas Jurídicas e imensas ONGs que cuidam da defesa de direitos".

\footnotetext{
${ }^{108}$ CANÁRIO, Pedro. Advogados se voltam contra Resolução Pro Bono da OAB-SP. Disponível em <http://www.conjur.com.br/2013-fev-23/grandes-nomes-advocacia-voltam-resolucao-probono-oab-sp>. Acesso em: 10/10/2016.

${ }^{109}$ MONTEIRO, Thiciane Araújo. Advocacia Pro Bono à luz da Ética. Disponível em: <http://thicidireito.jusbrasil.com.br/artigos/296276676/advocacia-pro-bono-a-luz-da-etica> . Acesso em: 04/07/2016.
} 
Assim sendo, a ideia de uma Rede de Proteção Judicial corrobora a tese de que as duas modalidades de advocacia, isto é, a gratuita e a privada de interesse público, podem e devem conviver harmonicamente.

Isto porque, segundo seu entendimento, no Brasil há uma gama enorme de agentes, cuja função precípua consiste na prestação de assistência jurídica a quem necessita, seja por parte do setor público ou privado, o que forma um verdadeiro exército capaz de atuar na defesa dos interesses e direitos violados. ${ }^{110}$

Assim sendo, Flávio Caetano acredita que atualmente possuímos um ambiente político bastante favorável a essa comunhão de esforços, fato que enseja uma política nacional de acesso à justiça.

Cumpre observar, por oportuno, que o secretário da Reforma do Judiciário enfatiza a importância do incentivo à advocacia solidária para que a supracitada política nacional efetivamente seja implementada, assim asseverando: “(...) um país que tem mais de 800 mil advogados pode utilizá-los também em processos de justiça para a população mais pobre". ${ }^{111}$

Seguindo a mesma linha dos supracitados juristas e considerando a notória frase do ministro Gilmar Mendes de que "há pobre para todos", Alberto Zacharias Toron afirma categoricamente que a atividade pro bono e o dever do Estado em prestar assistência jurídica gratuita não são institutos que se excluem. Pelo contrário: devem caminhar juntos, tendo em vista que, em suas palavras, o que caracteriza a advocacia é exatamente o exercício fraterno. ${ }^{112}$

Acrescenta, ainda, Marcos Henrique Caetano do Nascimento que a parceria firmada entre a Defensoria Pública e a advocacia pro bono ensejaria uma gama de benefícios para a população a partir da troca de

\footnotetext{
${ }^{110}$ CANÁRIO, Pedro. Advogados se voltam contra Resolução Pro Bono da OAB-SP. Disponível em <http://www.conjur.com.br/2013-fev-23/grandes-nomes-advocacia-voltam-resolucao-probono-oab-sp>. Acesso em: 10/10/2016.

${ }^{111}$ JUSTIÇA, Secretaria de Reforma do Judiciário do Ministério da Justiça. Disponível em: $<$ http://www.justica.gov.br/noticias/secretario-de-reforma-do-judiciario-defende-politica-nacionalde-acesso-a-justica-1>. Acesso em: 08/08/2016.

${ }^{112}$ CANÁRIO, Pedro. Advogados se voltam contra Resolução Pro Bono da OAB-SP. Disponível em <http://www.conjur.com.br/2013-fev-23/grandes-nomes-advocacia-voltam-resolucao-probono-oab-sp>. Acesso em: 10/10/2016.
} 
experiências entre essas duas modalidades, bem como permitira um maior fomento à capacitação dos praticantes, elaboração de seminários e debates acerca do tema e, principalmente, a supressão das lacunas existentes no tocante ao acesso à justiça. ${ }^{113}$

Cumpre ressaltar, por fim, que a própria Declaração Pro Bono das Américas prevê a atuação do profissional legal, isto é, do advogado, em colaboração com o Estado e o Poder Judiciário, a fim de promover um justo e equitativo sistema legal. ${ }^{114}$

Por todo o exposto neste item, conclui-se que a advocacia prestada com outras modalidades apresentadas no capítulo anterior, em um instrumento complementar e subsidiário à advocacia pública gratuita, jamais podendo ser vista como uma ferramenta de substituição desta, devido ao caráter obrigatório é de competência do Poder Público.

\subsection{Advocacia pro bono x Assistencialismo}

Importante esclarecer que a advocacia pro bono até então estudada, compreendida como a prestação de serviços jurídicos de forma gratuita e voluntária àqueles que não possuem meios financeiros para contratar um profissional do Direito, não se confunde com o mero assistencialismo ou caridade.

Decerto, ambas as modalidades consistem em uma assistência jurídica gratuita e voluntária realizada por advogados e estudantes de Direito destinada às pessoas hipossuficientes.

Ocorre que, conforme salienta Marcos Henrique Caetano do Nascimento, estará caracterizado o assistencialismo nas hipóteses em que a

\footnotetext{
${ }^{113}$ NASCIMENTO, Marcos Henrique Caetano do. Advocacia pro bono e a democratização do acesso à justiça.Revista Jurídica Consulex, ano XVII, n. 398, 15 de ago de 2013. Pp. 36-37.

${ }^{114}$ Declaração Pro Bono das Américas. Disponível em: http://www.dhnet.org.br/direitos/deconu/a_pdf/declaracao_probono_para_as_americas.pdf.. Acesso em: 24/07/2016.
} 
prestação gratuita de serviços jurídicos for realizada pelo advogado de forma pessoal e assistemática. ${ }^{115}$

Seguindo esse diapasão, o supracitado autor entende estar a atividade imbuída de viés caritativo quando o profissional do Direito, sem cobrar honorários, patrocina causas de forma excepcional, de modo a atender voluntariamente apenas nas horas vagas.

A título de exemplo, pode-se citar o caso corriqueiro do advogado que, ao tomar conhecimento de que o porteiro de seu prédio necessita de assistência jurídica gratuita para fazer valer um direito seu outrora violado, lhe representa judicialmente.

Ressalte-se que, no exemplo acima, o referido profissional não possui o hábito de prestar seus serviços de forma gratuita, tampouco participa de um grupo ou instituição, cuja função precípua seja tutelar, graciosamente, os interesses dos hipossuficientes, razão pela qual se trata de uma modalidade assistemática e esporádica.

Todavia, importante salientar que o assistencialismo não deve ser menosprezado, eis que o advogado, ao prestar seus serviços de forma gratuita a quem necessita, mas não possui condições de arcar com os honorários advocatícios, cumpre com a função social de sua profissão, ainda que em favor apenas de uma única pessoa.

No tocante à sua permissão, mister asseverar que, conforme ressalta Luiz Flávio Borges D’Urso, a advocacia gratuita enquanto atividade caritativa jamais sofreu qualquer restrição por parte da Ordem dos Advogados do Brasil, eis que reside no íntimo de cada profissional, diferentemente do que ocorreu com a advocacia solidária. ${ }^{116}$

A advocacia pro bono, por sua vez, conforme leciona Marcos Henrique Caetano do Nascimento, possui um objetivo bem mais amplo do que buscar o altruísmo e a filantropia, à medida que essa atividade é

\footnotetext{
${ }^{115}$ NASCIMENTO, Marcos Henrique Caetano do. A advocacia pro bono e a democratização do acesso à justiça. Revista Jurídica Consulex, ano XVII, n. 398, 15 de ago de 2013. Pp. 36-37.

${ }^{116}$ D’URSO, Luiz Flávio Borges. Advocacia pro bono precisa de regras nacionais. Revista Jurídica Consulex, ano XVII, n. 398, 15 de ago de 2013. P. 35.
} 
pautada em regras que sistematizam a metodologia e organização dos trabalhos, a fim de atingir nível municipal, estadual e nacional. ${ }^{117}$

Destarte, a atividade solidária pressupõe um verdadeiro sistema, revestido de regras e metodologia específicas a serem seguidas por profissionais capacitados, a fim de prestarem, de forma regular, assistência jurídica gratuita aos economicamente necessitados, bem como difundir o conhecimento jurídico à população.

Insta salientar que, conforme ressalva Luiz Flávio Borges D’Urso, a prática pro bono, tendo em vista também ser realizada por pessoas jurídicas e de forma regular, necessita de uma regulamentação rígida, a fim de se evitar a violação dos princípios norteadores da Advocacia. ${ }^{118}$

Pelo exposto, a fim de uma melhor compreensão acerca das diferenças entre a advocacia pro bono e o simples assistencialismo apontadas acima, impõe-se analisar o quadro comparativo abaixo:

\begin{tabular}{|c|c|c|}
\hline & ADVOCACIAPRO BONO & ASSISTENCIALISMO \\
\hline Quanto à Natureza & Profissional & Caridade \\
\hline Quanto ao exercício & Exercida regularmente & Exercida esporadicamente \\
\hline $\begin{array}{l}\text { Quanto à necessidade } \\
\text { de regulamentação }\end{array}$ & $\begin{array}{c}\text { Necessita de regulamentação } \\
\text { rígida }\end{array}$ & $\begin{array}{c}\text { Prescinde de } \\
\text { regulamentação }\end{array}$ \\
\hline Quanto à Proibição & $\begin{array}{c}\text { Permissão questionada em } \\
\text { diversos Estados }\end{array}$ & $\begin{array}{c}\text { Sempre foi amplamente } \\
\text { permitida }\end{array}$ \\
\hline Quanto à forma & Constitui um verdadeiro sistema & Assistemático \\
\hline Quanto ao agente & $\begin{array}{l}\text { - Profissionais individuais; } \\
\text { - Escritórios de advocacia } \\
\text { - ONGs, OSCIPs e demais } \\
\text { pessoas jurídicas }\end{array}$ & - Profissionais individuais \\
\hline Quanto ao alcance & Municipal, estadual e nacional & Individual \\
\hline
\end{tabular}

Por todo o exposto neste item, conclui-se que a advocacia pro bono e o assistencialismo possuem objetivos distintos, eis que a primeira visa

\footnotetext{
117 NASCIMENTO, Marcos Henrique Caetano do. A advocacia pro bono e a democratização do acesso à justiça. Revista Jurídica Consulex, ano XVII, n. 398, 15 de ago de 2013. Pp. 36-37.

118 D’URSO, Luiz Flávio Borges. Advocacia pro bono precisa de regras nacionais. Revista Jurídica Consulex, ano XVII, n. 398, 15 de ago de 2013. P. 35.
} 
atender, nos níveis nacional, estadual e municipal, a latente demanda da sociedade pelo acesso à justiça, enquanto a segunda, por não ser estruturada e nem exercida regularmente, se restringe à atuação individual de uma pessoa escolhida pelo advogado, limitando-se à mera caridade. 


\section{CAPÍTULO 3 - ADVOCACIA PRO BONO: FUNDAMENTO LEGAL E POSIÇÕES DOUTRINÁRIAS}

\subsection{Leis e disposições normativas atuais}

Incontestável que o Código de Ética e Disciplina da $\mathrm{OAB}$ pôs fim à longa discussão travada acerca da possibilidade de se praticar a advocacia pro bono, eis que permitiu expressamente, em seu artigo 30, o exercício da atividade todo o território brasileiro.

A fim de complementar a regulamentação do supracitado diploma, foi editada a Resolução n. 166/2015 pelo Conselho Federal da OAB, a qual estabelece limites a serem seguidos pelos advogados solidários, visando coibir eventuais abusos decorrentes dessa prática.

Ocorre que a essência da advocacia pro bono, isto é, a prestação de assistência jurídica gratuita e integral, por advogados privados, àqueles que não possuem recursos financeiros para arcar com as custas dos honorários advocatícios sem o prejuízo de seu sustento ou do de sua família, desde sempre esteve assegurada, ainda que implicitamente, nas mais variadas disposições normativas. É o que se analisará a seguir.

Primeiramente, cumpre observar que já no primeiro Estatuto da Advocacia da $\mathrm{OAB}$, elaborado em 1930, encontrava-se positivada a função social da advocacia, eis que seu artigo $1^{\circ}$ previa como dever do profissional do Direito a defesa dos interesses dos hipossuficientes. ${ }^{119}$

Imperioso destacar que, da mesma forma, o Estatuto da Advocacia da $\mathrm{OAB}$ vigente prevê, em seu artigo $2^{\circ}$, parágrafo $1^{\circ}$, que o advogado presta serviço público e exerce função social.

Assim, conforme anteriormente visto, a função social da advocacia é exercida toda vez que o profissional aplica suas habilidades funcionais a um comportamento ético e socialmente responsável, como é o caso, por

\footnotetext{
${ }^{119}$ FUCHS, Marcos Roberto. Advocacia pro bono e o novo Código de Ética e Disciplina. Revista do Advogado da AASP, n. 129, abril de 2016. Pp. 72-79.
} 
exemplo, da prestação de assistência jurídica gratuita àqueles que de outra forma não teriam seus direitos defendidos. ${ }^{120}$

A Constituição da República, por seu turno, prevê no artigo $5^{\circ}$, inciso XXXV, a inafastabilidade da jurisdição como um direito fundamental, assegurando o pleno acesso à justiça a todos os indivíduos. Ademais, em seu artigo 133, a Carta Magna eleva o advogado ao patamar de profissional imprescindível à administração da justiça.

Assim sendo, a partir de uma leitura sistemática dos referidos dispositivos constitucionais, extrai-se que o advogado, essencial ao manejo da justiça, possui o dever implícito de auxiliar na promoção do acesso integral à justiça, o que pode ser feito através da advocacia pro bono.

Acrescente-se, ainda, que a Constituição da República, em seu artigo $5^{\circ}$, inciso XIII, e o artigo $7^{\circ}$, inciso I, do Estatuto da Advocacia da OAB vigente, asseguram a todos os indivíduos o livre exercício de sua profissão, desde que atendidos os requisitos legais. ${ }^{121}$

Destarte, como não há nenhum dispositivo vedando a prática da advocacia solidária, extrai-se que essa atividade alinha-se com as normas e princípios norteadores da Lei Maior, bem como com os dispositivos infraconstitucionais, devendo, inclusive, ser incentivada.

Insta salientar, quanto ao Código de Ética e Disciplina, que o exercício da advocacia pro bono encontra-se implicitamente previsto entre os princípios norteadores utilizados na elaboração do referido diploma, ao passo que afirma dever ser a advocacia realizada com desprendimento, sempre priorizando a finalidade social do trabalho ao invés do ganho material. $^{122}$

\footnotetext{
${ }^{120}$ MODÉ, Fernando Magalhães. A função social do advogado e a advocacia pro bono. Revista de Direito do Terceiro Setor - RDTS, ano 1, n. 1, jan/ jun. 2007. Disponível em: <http://www.editoraforum.com.br/ef/wp-content/uploads/2016/08/funcao-social-doadvogado.pdf. >. Acesso em: 04/08/2016.

${ }^{121}$ CANÁRIO, Pedro. Advogados se voltam contra Resolução Pro Bono da OAB-SP. Disponível em <http://www.conjur.com.br/2013-fev-23/grandes-nomes-advocacia-voltam-resolucao-probono-oab-sp>. Acesso em: 10/10/2016.

${ }^{122} \mathrm{OAB}$, Conselho Federal. Resolução n. 02/2015 - Código de Ética e Disciplina da Ordem dos Advogados do Brasil. Brasília: 19 de outubro de 2015. Disponível em: <
} 
Nessa seara, o artigo $2^{\circ}$ do mesmo Código ressalta que o advogado possui função pública, eis que é defensor do Estado Democrático de Direito, dos direitos humanos, das garantias fundamentais, da cidadania e da justiça. O referido diploma dispõe, ainda, no artigo $3^{\circ}$, que o profissional deve ter consciência de que o Direito serve de instrumento para mitigar as desigualdades e garantir a igualdade.

Cumpre ressaltar, por oportuno, que nas últimas décadas ocorreram diversos encontros nos Estados Unidos, Peru, México, Chile, Argentina e Brasil, a fim de elaborar um documento capaz de estabelecer e fomentar a prática da advocacia pro bono nos países do continente Americano. Assim, em 2005, nasceu a Declaração Pro Bono para as Américas, em Nova Iorque. ${ }^{123}$

Importante asseverar que a Declaração Pro Bono para as Américas não é de observância obrigatória, tendo em vista que deve ser subscrita por advogados, escritórios de advocacia e entidades, cuja função seja promover a assistência jurídica gratuita, que desejem aderir à causa.

Não obstante a ausência de força normativa, o referido documento é de tamanha importância que merece estar elencado no presente tópico, eis que evidencia a tendência mundial da responsabilidade social da advocacia através da atividade pro bono, principalmente ao ressaltar que diversos países vêm implementando tradições e esforços acerca de seu exercício.

Ao ratificar o diploma, os subscritores se comprometem a adotar uma série de medidas, a fim de realizar e fomentar a advocacia pro bono, tais como: proporcionar acesso significativo ao sistema jurídico àqueles não possuem meios para fazê-lo, praticar a advocacia pro bono por mais de 25 horas ou três dias por ano, no caso de profissionais autônomos, ou por uma média de 25 horas por advogado por ano, no caso das firmas.

\footnotetext{
http://www.oab.org.br/arquivos/resolucao-n-022015-ced-2030601765.pdf $>$. Acesso em: 30/10/2016.

${ }^{123}$ Declaração Pro Bono das Américas. Disponível em: $<$ http://www.dhnet.org.br/direitos/deconu/a_pdf/declaracao_probono_para_as_americas.pdf.>.Ace sso em: $24 / 07 / 2016$.
} 
Insta observar, oportunamente, que a Declaração Pro Bono para as Américas considera diversas circunstâncias que evidenciam a necessidade da prestação de serviços jurídicos de forma solidária.

Seguindo esse diapasão, o diploma admite que o acesso à justiça é fundamental para a consolidação das sociedades democráticas, porém reconhece que o Estado, diante da limitação de seus recursos, não consegue assegurá-lo à enorme demanda.

Assim sendo, o documento em questão ressalta a importância da colaboração de todos os órgãos e entidades, privados e públicos, na construção de um sistema de justiça equitativo e inclusivo, principalmente por parte dos advogados, eis que esses possuem todos os meios para ampliação do acesso à justiça.

Por todo o acima exposto, conclui-se que a advocacia pro bono possui previsão legal expressa no ordenamento jurídico brasileiro, bem como seus ideários estão contemplados em diversos diplomas, em especial na Constituição da República.

\subsection{Discussão doutrinária acerca da advocacia pro bono}

Conforme mencionado no presente trabalho, a advocacia pro bono sofreu, ao longo de sua história, rigorosas críticas provenientes de diversos setores da comunidade jurídica, visando obstar sua institucionalização.

Assim sendo, esse tópico destina-se a apresentar as três principais teses contrárias à implementação da advocacia solidária e seus contraargumentos, quais sejam: a captação de clientela, a concorrência desleal e a substituição do Estado na prestação de assistência jurídica aos hipossuficientes.

Ainda, o presente item visa ressaltar os argumentos doutrinários que legitimam e embasam a prática pro bono.

Cumpre salientar, por oportuno, que os argumentos contrários perderam considerável força após a regulamentação nacional da advocacia 
pro bono, eis que, atualmente, incontestável que a prática em questão é considerada uma atividade ética e permitida, vez que seu exercício se encontra expressamente previsto no Código de Ética e Disciplina da OAB.

\subsubsection{Captação de clientela e promoção pessoal}

$\mathrm{O}$ argumento a ser tratado no presente tópico consiste em um dos principais fundamentos asseverado pela corrente oposta à institucionalização da advocacia pro bono, tendo sido recorrentemente utilizado pelas Seccionais da $\mathrm{OAB}$ que adotavam uma postura negativa em relação à essa prática.

Conforme essa tese, entendia-se que a advocacia solidária, em sua essência uma prática social e benevolente, poderia facilmente se coadunar em uma captação de clientela, fazendo com que os advogados a utilizassem como instrumento para se promoverem pessoalmente e, de forma transversa, angariarem clientes, violando expressamente o artigo 30, parágrafo terceiro, do Código de Ética e Disciplina da OAB. ${ }^{124}$

Ademais, a promoção pessoal implicaria em uma espécie de "estratégia de marketing", fato que contribuiria para a mercantilização da profissão, o que é vedado pelo artigo $5^{\circ}$ do Estatuto da Advocacia da OAB. ${ }^{125}$

Ocorre que, segundo assevera o jurista Oscar Vilhena Vieira, as alegações acima não se sustentam, eis que, como afirma, há regras rigorosamente estabelecidas pela Ordem dos Advogados do Brasil, a fim de coibir esses abusos, previstas no artigo 30 do Código de Ética. ${ }^{126}$

\footnotetext{
${ }^{124} \mathrm{OAB}$, Conselho Federal. Resolução n. 02/2015 - Código de Ética e Disciplina da Ordem dos Advogados do Brasil. Brasília: 19 de outubro de 2015. Disponível em: <http://www.oab.org.br/arquivos/resolucao-n-022015-ced-2030601765.pdf>. Acesso em: 30/10/2016.

${ }^{125}$ COSTA, Marco Antônio Moreira da. O papel da advocacia solidária na ampliação do acesso à justiça. Disponível em: <http://www.webartigos.com/artigos/o-papel-da-advocacia-solidaria-naampliacao-do-acesso-a-justica/98600/> . Acesso em: 13/09/2016.

${ }^{126}$ VIEIRA, Oscar Vilhena. Três teses equivocadas sobre "pro bono". Disponível em: <http://www1.folha.uol.com.br/fsp/opiniao/fz0903200610.htm >. Acesso em: 05/06/2016.
} 
Destarte, o profissional que presta seus serviços de forma pro bono encontra-se impedido de advogar para membros de conselhos ou mesmo empresas ligadas às organizações beneficiárias de seus serviços gratuitos, fazendo com que uma pessoa jurídica integrante do terceiro setor jamais possa servir de "trampolim" para um contrato remunerado. ${ }^{127}$

Acerca do referido temor, Miguel Reale Júnior ressalta a incoerência em proibir a advocacia pro bono em razão do presente argumento, salientando que "vetar a advocacia solidária com o receio de que algum tipo de cooptação venha a ocorrer é o mesmo que fechar a Bolsa de Valores por causa do temor de uma fraude". ${ }^{128}$

Outro ponto elucidado pela corrente contrária, no tocante ao argumento ora tratado, consiste na questão da fidelização dos clientes pro bono, tendo em vista que o advogado, ao prestar serviços jurídicos gratuitos a alguém, estaria "fidelizando" essa pessoa, a qual a contrataria novamente em ocasião futura, porém desta vez arcando com seus honorários advocatícios. ${ }^{129}$

Todavia, o supramencionado argumento igualmente não se sustenta, uma vez que a regulamentação da advocacia pro bono dispõe de regras e mecanismos capazes de coibir especificamente esse tipo de abusos.

Corroborando a afirmação acima, o Ato Provimento n. 166/2015, em seu artigo $4^{\circ}$ e parágrafos, atentando à questão da fidelização, determinou o impedimento de advogados, escritórios de advocacia e empresas que realizam a advocacia pro bono, por três anos a contar do encerramento do

\footnotetext{
${ }^{127}$ VIEIRA, Oscar Vilhena. Três teses equivocadas sobre "pro bono". Disponível em: <http://www1.folha.uol.com.br/fsp/opiniao/fz0903200610.htm >. Acesso em: 05/06/2016.

${ }^{128}$ NASCIMENTO, Gilberto. Advogados do Bem. Disponível em: 〈http://www2.uol.com.br/aprendiz/n_colunas/g_nascimento/ge081003.htm>. Acesso em: 08/10/2016.

${ }^{129}$ GHIRELLO, Mariana. Corporativismo impede advogados de trabalhar sem cobrar. Disponível em: <http://www.cartacapital.com.br/sociedade/corporativismo-impede-advogados-de-trabalharsem-cobrar-3414.html>. Acesso em: 27/07/2016.
} 
serviço gratuito prestado, para exercer advocacia remunerada às pessoas que utilizaram seus serviços pro bono. ${ }^{130}$

O supramencionado documento, ainda, vedou a possibilidade de condicionar a advocacia solidária à contratação de serviços remunerados.

Cumpre ressaltar, por oportuno, que a Ordem dos Advogados do Brasil, principalmente a Seccional de São Paulo, se valeu do argumento ora em questão, visando garantir, mediante rigorosa pressão corporativa, renda mínima aos 47 mil advogados inscritos, no ano de 2011, no convênio realizado entre a Defensoria Pública e a OAB-SP. ${ }^{131}$

Seguindo esse diapasão, conforme ressaltam Nádia Barros e Marcos Fuchs, a OAB-SP utilizou esse argumento durante doze anos, a fim de garantir a fidelidade de milhares de advogados dependentes do convênio, em vez de contribuir para o integral acesso à justiça, estendendo-o a um enorme contingente de pessoas que estão à margem do Poder Judiciário e, por isso, não têm como efetivar seus direitos. ${ }^{132}$

No mesmo sentido, durante o julgamento da ADI 4163, no qual o STF declarou a inconstitucionalidade de dois artigos da Constituição do Estado de São Paulo, os quais previam a obrigatoriedade da Defensoria Pública firmar convênio exclusivamente com a OAB-SP, o ministro Dias Toffoli, ao proferir seu voto, assim asseverou: "nem tanto a defender as pessoas hipossuficientes, mas os advogados hipossuficientes, criando uma reserva de mercado". 133

Por todo o exposto nesse capítulo, a tese ora guerreada revela-se infundada, tendo em vista, principalmente, as rigorosas regras estabelecidas tanto pelo Código de Ética e Disciplina da OAB, quanto pelo provimento $166 / 2015$.

\footnotetext{
130 BRASIL, Conselho Federal da Ordem dos Advogados do. Ato Provimento n. 166/2015. Disponível em: <http://www.oab.org.br/noticia/29076/oab-edita-provimento-que-regulamenta-aadvocacia-pro-bono>. Acesso em: 27/10/2016.

${ }^{131}$ CASTRO, André Luís Machado de e Rafael Morais Português de Souza. Retrocesso e Corporativismo. Disponível em: <LINK>. Acesso em: 16/10/2016.

${ }^{132}$ FUCHS, Marcos e Nádia Barros. Ideal da advocacia pro bono enfrenta obstáculos da OAB. Disponível em: <http://www.conjur.com.br/2013-nov-20/ideal-advocacia-pro-bono-enfrentaobstaculos-impostos-oab>. Acesso em: 22/07/2016.

${ }^{133}$ STF, ADI 4163/SP, Rel. Ministro Cezar Peluso, Brasília, 29 de fevereiro de 2012.
} 


\subsubsection{Concorrência desleal}

O segundo argumento evocado pela corrente contrária à advocacia pro bono consiste na preocupação de que o exercício dessa prática ensejaria uma competição injusta no mercado de trabalho, o qual encontra-se bastante inchado considerando o excedente de bacharéis que não consegue uma boa posição, caracterizando, assim, a concorrência desleal. ${ }^{134}$

Dessa forma, o exercício da advocacia solidária acabaria por diminuir ainda mais os clientes disponíveis, minando, assim, a função dos advogados dativos e dos pequenos escritórios de regiões afastadas. ${ }^{135}$

Ocorre que, como afirma Alberto Zacharias Toron, o argumento ora tratado não merece respaldo, tendo em vista que as pessoas beneficiárias da advocacia solidária se encontram, na maioria das vezes, abaixo da linha de miséria, sendo certo que jamais poderão contratar um advogado particular para defender seus interesses. ${ }^{136}$

Destarte, conforme assevera Marcos Antônio Moreira da Costa, o argumento em questão implica em desconsiderar a situação de insuficiência de recursos econômicos dos indivíduos, interpretação essa que leva a crer que as pessoas procuram os serviços pro bono, pois são aproveitadoras e não porque de fato carecem de condições financeiras para arcar com um profissional da área. ${ }^{137}$

Ressalte-se, por oportuno, que, conforme alega Oscar Vilhena Vieira, o exercício da advocacia solidária, ao contrário do que se argumenta, acaba por expandir os postos de trabalho ao invés de saturar ainda mais o mercado.

\footnotetext{
${ }^{134}$ VIEIRA, Oscar Vilhena. Três teses equivocadas sobre "pro bono". Disponível em: <http://www1.folha.uol.com.br/fsp/opiniao/fz0903200610.htm >. Acesso em: 05/06/2016.

${ }^{135} \mathrm{FUCHS}$, Marcos e Nádia Barros. Ideal da advocacia pro bono enfrenta obstáculos da OAB. Disponível em: <http://www.conjur.com.br/2013-nov-20/ideal-advocacia-pro-bono-enfrentaobstaculos-impostos-oab>. Acesso em: 22/07/2016.

${ }^{136}$ CANÁRIO, Pedro. Advogados se voltam contra Resolução Pro Bono da OAB-SP. Disponível em <http://www.conjur.com.br/2013-fev-23/grandes-nomes-advocacia-voltam-resolucao-probono-oab-sp>. Acesso em: 10/10/2016.

${ }^{137}$ COSTA, Marco Antônio Moreira da. O papel da advocacia solidária na ampliação do acesso à justiça. Disponível em: <http://www.webartigos.com/artigos/o-papel-da-advocacia-solidaria-naampliacao-do-acesso-a-justica/98600/>. Acesso em:13/09/2016.
} 
Isso porque a advocacia pro bono consiste não em uma assistência jurídica gratuita esporádica e eventual, mas sim em uma atividade regular que pressupõe um sistema composto de organização, metodologia e capacitação, compreendendo necessariamente uma estrutura dentro dos escritórios de advocacia. ${ }^{138}$

Assim sendo, segundo seu raciocínio, a fim de atender a enorme demanda pro bono, as firmas de advocacia necessariamente teriam que ampliar seus quadros de profissionais, visando expandir as horas trabalhadas. ${ }^{139}$

A título de exemplo, o escritório Siqueira Castro Advogados, já em 2007, possuía 269 advogados envolvidos com causas pro bono, sendo certo que a firma dedicava 10 horas mensais de assistência jurídica gratuita às 13 entidades sem fins lucrativos parceiras. ${ }^{140}$

Acrescenta-se, ainda, que diferentemente do que afirma a corrente opositora, a advocacia pro bono, não cria uma competição injusta no mercado, eis que, em verdade, permite uma concorrência justa e saudável.

Conforme explica Marco Antônio Moreira da Costa, os grandes escritórios de advocacia, cuja estrutura permite um setor destinado exclusivamente para a atividade pro bono, competem não com os pequenos escritórios de região afastada ou os advogados autônomos, e sim com as bancas de perfil semelhante no tocante aos trabalhos sociais e solidários. ${ }^{141}$

Por fim, salientam Oscar Vilhena Vieira e Fernando Magalhães Modé que a advocacia pro bono, ao patrocinar os interesses de pessoas que de outra forma não conseguiriam obter essa tutela, possibilita a formulação de demandas jurídicas até então reprimidas, obrigando o pólo passivo a

\footnotetext{
${ }^{138}$ NASCIMENTO, Marcos Henrique Caetano do. Advocacia pro bono e a democratização do acesso à justiça. Revista Jurídica Consulex, ano XVII, n. 398, 15 de ago de 2013. Pp. 36-37.

${ }^{139}$ VIEIRA, Oscar Vilhena. Três teses equivocadas sobre "pro bono". Disponível em: <http://www1.folha.uol.com.br/fsp/opiniao/fz0903200610.htm >. Acesso em: 05/06/2016.

${ }^{140}$ INVERNIZZI, Gabriela. Advocacia Pro Bono cresce e melhora imagem de escritórios. Disponível em: <http://www.conjur.com.br/2007-dez08/advocacia_pro_bono_cresce_melhora_imagem_escritorios>. Acesso em: 16/06/2016.

${ }^{141}$ COSTA, Marco Antônio Moreira da. O papel da advocacia solidária na ampliação do acesso à justiça. Disponível em: <http://www.webartigos.com/artigos/o-papel-da-advocacia-solidaria-naampliacao-do-acesso-a-justica/98600/>. Acesso em: 13/09/2016.
} 
contratar um advogado para se defender, e, consequentemente, aumentando a demanda por advogados. ${ }^{142}$

\subsubsection{Substituição do Estado na prestação de assistência jurídica gratuita}

Cumpre ressaltar, inicialmente, que a tese em questão se preocupa com a possibilidade da advocacia pro bono substituir o Estado no seu dever constitucional de prestação de assistência jurídica gratuita, realizada principalmente pelas Defensorias Públicas, de modo a violar expressamente o artigo $5^{\circ}$, inciso LXXIV, da Constituição Federal.

Ocorre que não merece respaldo o argumento em questão, eis que, ainda que tal pretensão fosse verdade, jamais seria viável, tendo em vista a quantidade homérica de hipossuficientes existentes no Brasil pugnando por acesso ao Poder Judiciário.

Ora, se nem mesmo o Estado, com seus substanciais, porém limitados, recursos destinado especialmente ao oferecimento da advocacia pública gratuita é capaz de suprir a demanda existente, que dirá a advocacia pro bono, a qual encontra-se, atualmente, ainda em estágio embrionário e, portanto, sem estrutura material para assumir tal responsabilidade. ${ }^{143}$

Seguindo esse diapasão, certo é que a proposta da advocacia pro bono consiste em contribuir subsidiariamente ao Estado na ampliação do acesso à justiça às classes mais desfavorecidas, integrando a denominada Rede de Proteção Judicial defendida pelo Secretário de Reforma do Judiciário, e não concorrer com o Poder Público pelo monopólio da miséria. ${ }^{144}$

\footnotetext{
${ }^{142}$ MODÉ, Fernando Magalhães. A função social do advogado e a advocacia pro bono. Belo Horizonte: Revista de Direito do Terceiro Setor - RDTS, ano 1, n. 1, jan/ jun. 2007. Disponível em: $\quad<$ http://www.editoraforum.com.br/ef/wp-content/uploads/2016/08/funcao-social-doadvogado.pdf. $>$. Acesso em: 04/08/2016.

${ }^{143}$ VIEIRA, Oscar Vilhena. Três teses equivocadas sobre "pro bono". Disponível em: <http://www1.folha.uol.com.br/fsp/opiniao/fz0903200610.htm >. Acesso em: 05/06/2016.

${ }^{144}$ CANÁRIO, Pedro. Advogados se voltam contra Resolução Pro Bono da OAB-SP. Disponível em: $\quad<$ http://www.conjur.com.br/2013-fev-23/grandes-nomes-advocacia-voltam-resolucao-probono-oab-sp>. Acesso em: 10/10/2016.
} 
Nessa vereda ressaltou o ministro Gilmar Mendes:

"De modo que me parece fundamental haver uma articulação; que a Defensoria Pública tenha um papel central, como órgão central de coordenação desse tipo de atividade. Mas não me parece que possamos estabelecer essa ideia de monopólio".

Oscar Vilhena Vieira possui o mesmo entendimento acerca do caráter subsidiário da advocacia pro bono, acrescentando que a articulação proporcionará o fortalecimento dos laços de solidariedade entre as pessoas, bem como auxiliará o Estado a fazer melhor uso de seus recursos financeiros. ${ }^{145}$

Conforme anteriormente explanado em tópico próprio, no qual se discutiu a possibilidade de coexistirem, no mesmo cenário, a advocacia pública gratuita e a advocacia privada de interesse público, extrai-se que a ambas as modalidades não só se complementam, como devem caminhar juntas para atingir o objetivo maior, que é a ampliação do acesso à justiça.

Dessa forma, considerando que nem o Estado e muito menos a advocacia pro bono possuem estrutura material e humana, a fim de, sozinhos, atenderem a homérica demanda de hipossuficientes que necessitam de assistência jurídica gratuita, imperioso se faz a criação e implementação efetiva da Rede de Proteção Judicial elaborada pelo Secretário de Reforma do Judiciário, Flavio Crocce Caetano. ${ }^{146}$

\subsubsection{Inconstitucionalidade na proibição da advocacia pro bono}

No tocante à proibição da prática pro bono, Marco Antonio Moreira da Costa evidencia que a advocacia é a única profissão na qual o voluntariado encontra resistências, sendo certo que, em se tratando de um

\footnotetext{
${ }^{145}$ VIEIRA, Oscar Vilhena. Três teses equivocadas sobre "pro bono". Disponível em: <http://www1.folha.uol.com.br/fsp/opiniao/fz0903200610.htm >. Acesso em: 05/06/2016.

${ }^{146}$ CANÁRIO, Pedro. Advogados se voltam contra Resolução Pro Bono da OAB-SP. Disponível em: <http://www.conjur.com.br/2013-fev-23/grandes-nomes-advocacia-voltam-resolucao-probono-oab-sp>. Acesso em: 10/10/2016.
} 
médico ou dentista, todos acreditam ser moralmente justificável o atendimento gratuito às camadas menos abastadas. ${ }^{147}$

Assim sendo, pergunta-se: por que os advogados não podem atender de graça? Por que seria uma conduta antiética o profissional do Direito prestar serviços gratuitamente e o médico não?

Insta recordar que, como anteriormente exposto, durante longos anos diversos Tribunais de Ética e Disciplina da OAB fixaram o entendimento de que a advocacia gratuita seria nociva à profissão, impedindo os advogados de exercê-la livremente. ${ }^{148}$

Todavia, a renomada professora Flávia Piovesan afirma ser a referida proibição patentemente inconstitucional, ao passo que viola o direito fundamental positivado no artigo $5^{\circ}$, inciso XIII, da Constituição Federal, o qual assegura a todo profissional o "livre exercício de qualquer trabalho, ofício ou profissão". ${ }^{149}$

Destarte, segundo explica a professora de Direito Constitucional, tendo em vista a lei não prever nada mais a respeito - até porque, nas palavras da autora, se o fizesse, estaria reduzindo de forma inconstitucional o acesso à justiça -, entende-se que não há se falar em proibição da prestação de serviços graciosos pelo advogado, principalmente a quem necessita, eis que tudo o que não é proibido, é permitido.

Felizmente, o Código de Ética e Disciplina vigente pôs fim à controvérsia quanto o caráter ético da advocacia pro bono, permitindo, enfim, o exercício da advocacia pro bono em favor de pessoas naturais e

\footnotetext{
${ }^{147}$ COSTA, Marco Antônio Moreira da. O papel da advocacia solidária na ampliação do acesso à justiça. Disponível em: <http://www.webartigos.com/artigos/o-papel-da-advocacia-solidaria-naampliacao-do-acesso-a-justica/98600/>. Acesso em: 13/09/2016.

${ }^{148}$ COSTA, Marco Antônio Moreira da. O papel da advocacia solidária na ampliação do acesso à justiça. Disponível em: <http://www.webartigos.com/artigos/o-papel-da-advocacia-solidaria-naampliacao-do-acesso-a-justica/98600/>. Acesso em: 13/09/2016.

${ }^{149}$ CANÁRIO, Pedro. Advogados se voltam contra Resolução Pro Bono da OAB-SP. Disponível em: $\quad<$ http://www.conjur.com.br/2013-fev-23/grandes-nomes-advocacia-voltam-resolucao-probono-oab-sp>. Acesso em: 10/10/2016.
} 
jurídicas juridicamente hipossuficientes, desde que observados os limites impostos para coibir eventuais abusos dessa prática. ${ }^{150}$

\subsubsection{Importância da advocacia pro bono na transformação da realidade brasileira}

\subsubsection{Benefício para a sociedade}

Conforme assinalado no capítulo anterior, o Estado Democrático de Direito concentra a função jurisdicional em um único Poder Público: o Judiciário. Por essa razão, a Constituição da República assegura o amplo acesso à justiça, bem como a inafastabilidade da jurisdição, impedindo que um indivíduo, cujo direito tenha sido violado, fique desamparado juridicamente.

Ocorre que, para que um indivíduo possa ingressar em juízo, a fim de obter uma tutela jurisdicional, é necessária a contratação de um profissional do Direito, eis que, conforme dispõe o artigo $1^{\circ}$ do Estatuto da Advocacia, a capacidade postulatória é atividade privativa do advogado ${ }^{151}$.

Todavia, se por um lado a maior parte da população brasileira não possui condições financeiras para arcar com os honorários advocatícios, por outro, a Defensoria Pública é insuficiente para, sozinha, suprir a demanda latente de hipossuficientes que necessitam de assistência jurídica integral e gratuita.

Por essa razão, Marcos Henrique Caetano do Nascimento entende que o advogado, ao exercer a atividade pro bono, possui o condão de transformar a realidade social, pois maximiza o acesso à justiça à medida

\footnotetext{
${ }^{150}$ NASCIMENTO, Marcos Henrique Caetano do. A advocacia pro bono e a democratização do acesso à justiça. Revista Jurídica Consulex, ano XVII, n. 398, 15 de ago de 2013. Pp. 36-37.

${ }^{151}$ PLANALTO. Lei $n^{o}$ 8.906, de 04 de julho de 1994 - Estatuto da Advocacia e a Ordem dos Advogados do Brasil $(O A B)$ Brasília. Disponível em: <http://www.planalto.gov.br/ccivil_03/leis/L8906.htm >. Acesso em: 30/10/2016.
} 
que presta serviços jurídicos àqueles que estão à margem da chancela jurisdicional. ${ }^{152}$

Ressalte-se, por oportuno, que o acesso à justiça é de suma importância, eis que, segundo Marcos Roberto Fuchs, o referido direito tem como consequência a consolidação do Estado de Direito, da democracia e dos direitos humanos, eis que possui relação direta com a proteção dos demais direitos. 153

No que tange à proteção dos demais direitos, Miguel Reale Júnior preleciona que a advocacia pro bono, através da qual o advogado exerce a responsabilidade social que sua profissão acarreta, possibilita aos marginalizados o acesso à justiça e a obtenção, de forma justa, da tutela de seu direito outrora violado. Acrescenta, que a advocacia solidária tem importante papel ao prestar assistência jurídica gratuita às entidades desprovidas de recursos financeiros, eis que amplia ainda mais seu alcance. $^{154}$

Insta salientar que o supramencionado autor alega, ainda, que a advocacia pro bono tem como um de seus objetivos conscientizar as pessoas acerca de seus direitos e deveres. Afinal, os indivíduos somente saberão que seus direitos estão sendo violados, se tiverem conhecimento desses.

Assim sendo, o IPB, por exemplo, ao realizar os mutirões em comunidades carentes, a fim de levar orientação jurídica a essa população por advogados e estudantes de Direito, bem como ao distribuir as denominadas Cartilhas Pro Bono, visando facilitar a compreensão das questões jurídicas, contribui para a democratização da informação, o que gera, em última análise, a promoção da cidadania. ${ }^{155}$

\footnotetext{
152 NASCIMENTO, Marcos Henrique Caetano do. Advocacia pro bono e a democratização do acesso à justiça. Revista Jurídica Consulex, ano XVII, n. 398, 15 de ago de 2013. Pp. 36-37.

${ }^{153}$ FUCHS, Marcos Roberto. Advocacia pro bono e o novo Código de Ética e Disciplina. Revista do Advogado da AASP, n. 129, abril de 2016. Pp. 72-79.

154 JÚNIOR, Miguel Reale. Advocacia pro bono: ocupação feliz. Revista do Advogado da AASP, n. 129, abril de 2016. Pp. 105-109.

155 JÚNIOR, Miguel Reale. Advocacia pro bono: ocupação feliz. Revista do Advogado da AASP, n. 129, abril de 2016. Pp. 105-109.
} 
Não por outra razão, o Instituo Pro Bono reconhece que a falta de acesso à justiça inviabiliza a própria cidadania para a maior parte da população, isto é, a juridicamente hipossuficiente. ${ }^{156}$

Insta salientar que a concepção de cidadania possui outra faceta além da informação, consistente na resolução de conflitos de forma digna, justa e civilizada, o que somente é alcançado através da obtenção de uma tutela jurisdicional precedida pela estrita observância do devido processo legal, garantia assegurada pela Constituição da República. ${ }^{157}$

A advocacia pro bono, portanto, se revela um poderoso instrumento para a conquista efetiva da cidadania por todos os indivíduos, ao passo que defende, em juízo, de forma gratuita e voluntária, os direitos daqueles que, a priori, estariam excluídos da chancela do Judiciário. Ademais, proporciona conhecimento jurídico aos indivíduos, contribuindo, assim, para a inclusão social e a promoção da cidadania através da ampliação do acesso à justiça. ${ }^{158}$

Imperioso ressaltar que a advocacia pro bono, em sua modalidade advocacy, constitui uma ferramenta excepcional na transformação da realidade social, tendo em vista que, ao buscar a implementação de políticas públicas, é capaz de promover e efetivar os direitos da coletividade, beneficiando milhares de brasileiros. ${ }^{159}$

Ademais, a advocacia solidária consiste em um mecanismo de promoção da igualdade, eis que equipara os indivíduos que não possuem recursos financeiros para contratar um advogado àqueles que são capazes

\footnotetext{
${ }^{156}$ BONO, Instituto Pro. Nota pública do Instituto Pro Bono sobre a suspensão das limitações à prática da advocacia pro bono no Brasil. Disponível em: <http://www.probono.org.br/notapublica-do-instituto-pro-bono-sobre-a-suspensao-das-limitacoes-a-pratica-da-advocacia-pro-bonono-brasil>. Acesso em: 10/10/2016.

${ }^{157}$ RÊGO, Humberto Henrique Costa Fernandes do e Victor dos Santos Maia Matos. Ética profissional e advocacia pro bono: o papel do advogado na conquista da cidadania. Revista do Advogado da AASP, n. 129, abril de 2016. Pp. 47-53.

${ }^{158}$ OLIVEIRA, Flávia Regina de Souza, et al. Advocacia Pro Bono: guia prático para escritórios. Disponível em: <http://www.cesa.org.br/arquivos/com_advcom_cartilha.pdf>. Acesso: 23/07/2016.

${ }^{159}$ NAVES, Rubens e Guilherme Amorim Campos da Silva. Advocacia pro bono e advocacy. Revista Jurídica Consulex, ano XVII, n. 398, 15 de ago de 2013. Pp. 38-39.
} 
de fazê-lo. Dessa forma, a assistência jurídica integral é garantida a todos os indivíduos por um profissional habilitado. ${ }^{160}$

Assim sendo, em uma sociedade caracterizada pela extrema desigualdade, a advocacia pro bono contribui para amenizar esse quadro, auxiliando a materialização da previsão constitucional consistente no pleno acesso à justiça.

Ressalte-se, por oportuno, que o próprio Código de Ética e Disciplina da $\mathrm{OAB}$, em seu artigo $3^{\circ}$, menciona que o advogado deve ter consciência de que o Direito é um instrumento capaz de mitigar as desigualdades. ${ }^{161}$

Paralelamente à diminuição da desigualdade existente no Brasil, a advocacia solidária possui o condão de materializar a dignidade da pessoa humana para as classes menos favorecidas, aumentando a qualidade de vida da população, bem como os fazendo se sentir definitivamente como sujeito de direitos.

Conforme asseveram os professores Rubens Naves e Guilherme Amorim Campos da Silva em artigo publicado acerca da advocacia probono, o princípio da dignidade da pessoa humana é plenamente observado toda vez que um indivíduo, cujos direitos foram indevidamente violados, é capaz de defendê-los juridicamente através de um profissional habilitado. ${ }^{162}$

Assim sendo, a advocacia pro bono contribui para uma sociedade mais justa à medida que possibilita a materialização da dignidade da pessoa

\footnotetext{
${ }^{160}$ BOTELHO, Augusto de Arruda. Advocacia pro bono e o amplo acesso à justiça. Revista Jurídica Consulex, ano XVII, n. 398, 15 de ago de 2013. Pp. 26-27.

${ }^{161} \mathrm{OAB}$, Conselho Federal. Resolução n. 02/2015 - Código de Ética e Disciplina da Ordem dos Advogados do Brasil. Brasília: 19 de outubro de 2015. Disponível em: <http://www.oab.org.br/arquivos/resolucao-n-022015-ced-2030601765.pdf >. Acesso em: 30/10/2016.

${ }^{162}$ NAVES, Rubens e Guilherme Amorim Campos da Silva. Advocacia pro bono e advocacy. Revista Jurídica Consulex, ano XVII, n. 398, 15 de ago de 2013. P. 38-39.
} 
humana aos indivíduos das classes menos abastadas, eis que de outro modo eles não teriam como proteger seus direitos. ${ }^{163}$

Por todo o exposto no presente tópico, conclui-se que a advocacia pro bono, juntamente com as demais modalidades de assistência jurídica integral e gratuita, seja pública ou privada, é um instrumento capaz de transformar a realidade social, tendo em vista que através da ampliação do acesso à justiça, contribui para mitigar as desigualdades, garantir a dignidade da pessoa humana, promover a cidadania e assegurar a materialização de todos os demais direitos.

\subsubsection{Benefício para o advogado solidário}

Por tudo o que já foi exposto, extrai-se que a advocacia pro bono visa, em última análise, estender o acesso à justiça àquela parcela da população que não possui o privilégio de contratar um advogado privado ou, por inúmeras razões, não consegue ser atendida pela Defensoria Pública.

Ocorre que, como melhor se analisará no presente tópico, a advocacia solidária possui outra faceta, destinada a beneficiar os próprios advogados que prestam seus serviços de forma gratuita.

Importante observar, primeiramente, que a advocacia pro bono consiste em uma atividade voluntária, ou seja, não obrigatória, razão pela qual os advogados a exercem porque gostam e se sentem felizes e não devido ao ganho financeiro.

Quanto a essas práticas de liberalidade, Ortega y Gasset as classifica como "ocupações felizes", em contraposição às "ocupações forçadas", as quais todas as pessoas estão sujeitas, visando o próprio sustento. ${ }^{164}$

\footnotetext{
${ }^{163}$ RÊGO, Humberto Henrique Costa Fernandes do e Victor dos Santos Maia Matos. Ética profissional e advocacia pro bono: o papel do advogado na conquista da cidadania. Revista do Advogado da AASP, n. 129, abril de 2016. P. 47-53.

${ }^{164}$ ORTEGA Y GASSET, José. La caza y los toros. 2. ed. Madrid: Revista do Ocidente, 1968. P. 30 .
} 
Seguindo esse diapasão, Miguel Reale Júnior salienta que, ao advogar pro bono, o profissional do Direito alcança a felicidade e o prazer, bem como satisfaz os ideais que norteiam seu projeto de vida, tornando-o mais completo como ser humano. ${ }^{165}$

Acrescenta-se, ainda, que ao incidir na esfera íntima dos profissionais do Direito, a atividade pro bono se mostra extremamente positiva, eis que aumenta a consciência cidadã dos advogados que a exercem e viabiliza uma maior conscientização acerca da função social de sua profissão, bem como do compromisso que possuem de transformar a realidade social brasileira, hoje tão miserável. ${ }^{166}$

Nádia Barros assevera que o graduando de Direito possui, ao longo de sua capacitação, uma formação humanística capaz de permitir uma compreensão acerca do fenômeno jurídico enquanto transformador da sociedade. ${ }^{167}$

Assim, a partir do supramencionado modelo de aprendizagem, o estudante de Direito, desde a origem de seus ensinamentos, desenvolve o senso ético-profissional, bem como obtém a noção da responsabilidade social que sua profissão carrega, sendo esses princípios balizadores da advocacia.

Insta salientar que o conselheiro federal Luiz Flávio Borges D’Urso possui pensamento similar, tendo em vista entender que a advocacia pro bono é de suma importância para o crescimento tanto profissional, quanto pessoal do advogado. ${ }^{168}$

Imperioso destacar, nesse momento, que as seccionais da American Bar Association, nos Estados Unidos, exigem a prestação de serviços pro bono aos advogados recém-formados e aos estudantes de direito, tendo em

\footnotetext{
${ }^{165}$ JÚNIOR, Miguel Reale. Advocacia pro bono: ocupação feliz. Revista do Advogado da AASP, n. 129, abril de 2016. Pp. 105-109.

${ }^{166}$ FUCHS, Marcos Roberto e Flávia Piovesan. Advocacia de interesse público e o Instituto Pro Bono. Revista Jurídica Consulex, ano XVII, n. 398, 15 de ago de 2013. Pp. 40-42.

${ }^{167}$ BARROS, Nádia e Marcos Roberto Fuchs. Por que os advogados não podem atender de graça? Disponível em: <http://reporterbrasil.org.br/2013/12/por-que-os-advogados-brasileiros-naopodem-atender-de-graca/>. Acesso em: 22/07/2016.

${ }^{168}$ D’URSO, Luiz Flávio Borges. Advocacia pro bono precisa de regras nacionais. Revista Jurídica Consulex, ano XVII, n. 398, 15 de ago de 2013. P. 35.
} 
vista que a instituição entende ser a referida atividade benéfica não só aos os assistidos, mas também ao próprio agente, eis que remodela suas atitudes políticas em relação à sociedade e ao Direito. ${ }^{169}$

Cumpre ressaltar, nesse diapasão, que a advocacia pro bono é especialmente benéfica para o advogado recém-formado ou ainda estagiário, eis que, além das benesses acima exaradas, a atividade solidária certamente contribuirá para a melhor capacitação do jovem, sendo a referida prática um diferencial em seu currículo. ${ }^{170}$

Por fim, entende-se que a advocacia pro bono possui o condão de transformar não só a sociedade, mas também o próprio agente que a exerce, tornando-o mais feliz, humano e capacitado.

\subsection{Próximos passos e desafios a serem superados}

Incontestável que o Código de Ética e Disciplina da OAB, ao regulamentar a prática da advocacia pro bono em nível nacional, proporcionou um significativo avanço. Todavia, conforme ressalta Marcos Fuchs, a fim de que haja a correta e efetiva implementação da advocacia solidária em nosso país, mister se faz enfrentar alguns desafios acerca do tema. ${ }^{171}$

O primeiro deles, segundo o presidente do Instituto Pro Bono, consiste na definição do conceito de advocacia pro bono, através da análise dos adjetivos previstos na parte inicial do parágrafo primeiro do artigo 30, quais sejam: "gratuita, eventual e voluntária", visando dirimir quaisquer dúvidas acerca da natureza desta prática.

Em segundo lugar, a fim de identificar os beneficiários desta atividade, imperioso se faz estabelecer quais são os requisitos a serem

\footnotetext{
${ }^{169}$ OLIVEIRA, Flávia Regina de Souza e Juliana Gomes Ramalho Monteiro. Levando o pro bono a sério. Revista Jurídica Consulex, ano XVII, n. 398, 15 de ago de 2013. Pp. 28-29.

${ }^{170}$ RIBEIRO, Paulo Afonso da Motta. O significado da advocacia pro bono. São Paulo: Revista Jurídica Consulex, ano XVII, n. 398, 15 de ago de 2013. Pp. 32-34.

${ }^{171}$ FUCHS, Marcos Roberto e Flávia Piovesan. Advocacia de interesse público e o instituto pro bono. Revista Jurídica Consulex, ano XVII, n. 398, 15 de ago de 2013. P. 40-42.
} 
preenchidos pelas pessoas, a fim de serem consideradas aptas ao atendimento pro bono.

Insta salientar, por oportuno, que, em café da manhã temático promovido pelo Instituto Pro Bono no dia 10 de dezembro de 2014, a fim de discutir a responsabilidade social exercida por advogados por meio da profissão, Marcos Fuchs ressaltou a importância da análise casuística acerca das condições financeiras de cada possível beneficiário, eis que entende não ser o ideal a fixação de critérios objetivos, tais como a renda mínima. ${ }^{172}$

$\mathrm{O}$ terceiro desafio, e talvez o mais importante, consiste em estabelecer meios capazes para fiscalizar e coibir eventuais abusos que possam decorrer da advocacia pro bono, principalmente no tocante à captação de clientela. ${ }^{173}$

Decerto, o Código de Ética e Disciplina aprovado no ano passado, apesar de ampliar a atuação pro bono no Brasil, igualmente estabeleceu, em seu artigo 30, alguns limites e regras à referida prática, a fim de coibir eventuais abusos decorrentes de seu exercício, quais sejam:

(i) empregar o zelo e dedicação habituais, isto é, o advogado que prestar seus serviços gratuitamente deverá fazê-lo com a mesma qualidade utilizada nos serviços jurídicos onerosos;

(ii) jamais poderá ser utilizada para fins político-partidários ou eleitorais, bem como para patrocinar os interesses de instituições que visem esse fim;

(iii) não servirá de instrumento para publicidade, visando a captação de clientela.

Ressalte-se, por oportuno, que quanto às restrições impostas pela nova regulamentação, mesmo a corrente mais adepta ao livre exercício da advocacia pro bono entende ser necessário estabelecer determinados limites para o exercício dessa prática, a fim de assegurar que seu real objetivo seja atingido sem que os receios do Código de Ética se materializem.

\footnotetext{
${ }^{172}$ RODAS, Sérgio. Pro bono é menos desenvolvido no Brasil do que no resto da América Latina. Disponível em: <http://www.conjur.com.br/2014-dez-13/pro-bono-desenvolvido-brasil-americalatina\#top>. Acesso em: 13 de julho de 016.

${ }^{173}$ FUCHS, Marcos Roberto. Advocacia pro bono e o novo Código de Ética e Disciplina. Revista do Advogado da AASP, n. 129, abril de 2016. Pp. 72-79.
} 
Nesse diapasão, Theresa Raquel Bethônico Corrêa entende que a prática solidária em questão deve ser fiscalizada através dos Tribunais de Ética e Disciplina da Ordem dos Advogados, os quais, a seu ver, são os órgãos responsáveis por coibir a concorrência desleal e a captação de clientela. ${ }^{174}$

Dessa forma, nas hipóteses em que os referidos limites não forem observados, cabe ao Código de Ética e Disciplina da OAB, como ferramenta adequada, aplicar as sanções disciplinares que julgar satisfatórias. $^{175}$

Outro desafio ressaltado pelo diretor do instituto Pro Bono consiste em uma análise sistemática acerca do instituto da advocacia solidária, a fim de considerar essa prática inserida num sistema de justiça, no qual existem outros atores similares, tais como a Defensoria Pública, os advogados dativos, o Ministério Público e o Poder Judiciário como um todo.

Como último desafio, a fim de que a advocacia solidária se transforme em uma realidade prática em nosso país, e não se limite apenas a uma determinação ética sem eficácia, imperiosa se faz a adoção de medidas para sua difusão e seu incentivo, tendo em vista que somente dessa forma será capaz de cumprir o objetivo principal de ampliação do acesso à justiça, visando reduzir o alarmante contexto de exclusão social existente.

Isso porque a institucionalização da advocacia pro bono através de uma regulamentação válida, por si só, não é o suficiente para que os milhares de advogados brasileiros se disponham a exercê-la, razão pela qual requer a imposição de medidas visando sua implementação.

No ano de 2014, a revista Latin Lawyer e o Cyrus R. Vance Center of International Justice realizaram pesquisa anual acerca do desenvolvimento

\footnotetext{
${ }^{174}$ CORRÊA, Theresa Raquel Bethônico. Advocacia Pro Bono: Assistencialismo ou Compromisso Social? Disponível

em: <http://tpmagister.lex.com.br/lexnet/lexnet.dll/Dout/2bd?f=templates\&fn=documentframe.htm\&2.0>. Acesso em: 21 de setembro de 2016.

${ }^{175}$ FUCHS, Marcos Roberto e Flávia Piovesan. Advocacia de interesse público e o instituto pro bono. Revista Jurídica Consulex, ano XVII, n. 398, 15 de ago de 2013. P. 40-42.
} 
da prática pro bono na América do Sul, na qual o Brasil se revelou o país menos desenvolvido.

Para a publisher da revista LatinLawyer, Clare Bolton, o supracitado fato se dá devido ao baixo nível de incentivos que os escritórios de advocacia dão à prática, sendo certo que apenas $32 \%$ das bancas consideram a atividade pro bono para aumentos de salário, bônus e progressão na carreira. ${ }^{176}$

Assim sendo, os escritórios de advocacia e as organizações civis comprometidas com a causa possuem papel relevantíssimo para a implementação efetiva desta prática, através da disseminação de informações acerca desta atividade, bem como a explanação de seus benefícios, visando incentivá-la cada vez mais.

Uma das medidas adotadas objetivando esse fim foi a elaboração, por parte do Centro de Estudos das Sociedades de Advogados - CESA, da denominada Cartilha Pro Bono, um guia prático para escritórios de advocacia consistente em esclarecer conceitos, apontar caminhos e explanar todos os benefícios da advocacia solidária. ${ }^{177}$

Nessa vereda, o ministro Gilmar Mendes, no julgamento da ADI 4163, evidenciou a necessidade do incentivo quanto à prática da advocacia pro bono, ressaltando a importância de uma articulação, com a Defensoria Pública no centro, de todos os agentes capazes de prover assistência jurídica gratuita a quem precisa, a fim de mudar a "vergonhosa" realidade social. Veja-se:

"Eu tenho a impressão de que deveria se incentivar - Ministro Cézar Peluzo que está na presidência do CNJ, e Vossa Excelência que está prestes a assumir - a advocacia pro bono, até mesmo oferecendo algum tipo de sanção premial, de convite, para que advogados prestassem esse tipo de advocacia.

(...)

\footnotetext{
${ }^{176}$ RODAS, Sérgio. Pro bono é menos desenvolvido no Brasil do que no resto da América Latina. Disponível em: <http://www.conjur.com.br/2014-dez-13/pro-bono-desenvolvido-brasil-americalatina\#top>. Acesso em: 13 de julho de 016.

177 OLIVEIRA, Flávia Regina de Souza, et al. Advocacia Pro Bono: guia prático para escritórios. Disponível em: 〈http://www.cesa.org.br/arquivos/com_advcom_cartilha.pdf〉. Acesso: 23/07/2016.
} 
Então, talvez pudéssemos incentivar, por exemplo, colocando que isso valeria ponto de títulos para concurso da advocacia, concursos da Defensoria, concursos do Ministério Público, por exemplo. São medidas que podem ser pensadas”. ${ }^{178}$

Cumpre ressaltar, por oportuno, que os tribunais igualmente podem e devem - contribuir de diversas formas para a fomentação da advocacia solidária em nosso país, sendo a já mencionada Resolução 62 do Conselho Nacional de Justiça um grande exemplo.

Por fim, o entusiasta do tema, Marcos Fuchs, evidencia a importância de, uma vez liberado o exercício da advocacia pro bono em favor das pessoas físicas, definir quais os nichos de atuação em que a advocacia solidária é mais demandada, a fim de, inicialmente, direcionar a prática pro bono para os que dela mais necessitam:

"Temos que começar pela mediação de conflitos, pela atuação em áreas bem
carentes e problemáticas de São Paulo onde a Defensoria Pública não está
presente, temos que eleger temas prioritários, como direito de família, área penal,
violência contra a mulher, quem sabe direito previdenciário também, e começar a
agir". ${ }^{179}$ Importante observar que o supracitado advogado afirmou ser a advocacia pro bono mais fundamental onde não há a atuação da Defensoria Pública ou de qualquer outro meio de assistência gratuita pública, evidenciando o caráter complementar e subsidiário da advocacia solidária no tocante à ampliação do acesso à justiça às classes desprivilegiadas.

Por todo o exposto, conclui-se que a regulamentação da advocacia pro bono a nível nacional, através do Código de Ética e Disciplina de 2015, se revela apenas o primeiro passo para a efetiva implementação desta atividade em nosso país, devendo esta ser, nos próximos anos, alvo de incansáveis debates, a fim de ser incentivada, estabelecer limites para coibir eventuais abusos e esclarecer quaisquer dúvidas acerca de sua natureza, o que facilmente poderá ensejar confusões.

\footnotetext{
${ }^{178}$ STF, ADI 4163/SP, Rel. Ministro Cézar Peluso, Brasília, 29 de fevereiro de 2012.

${ }^{179}$ RODAS, Sérgio. Pro bono é menos desenvolvido no Brasil do que no resto da América Latina. Disponível em: <http://www.conjur.com.br/2014-dez-13/pro-bono-desenvolvido-brasil-americalatina\#top>. Acesso em: 13 de julho de 016.
} 


\section{CONCLUSÃO}

Por todo o exposto no presente trabalho, extrai-se que a advocacia pro bono consiste em uma atividade gratuita, voluntária, sistematizada e regular de assistência jurídica prestada aos hipossuficientes, realizada por pessoas jurídicas ou físicas do setor privado que, conscientes de sua responsabilidade social, visam ampliar o pleno acesso à justiça, a fím de promover a dignidade da pessoa humana e a cidadania aos marginalizados.

Não obstante os argumentos contrários à implementação da advocacia pro bono no Brasil, como a captação de clientela, a concorrência desleal e a usurpação do dever do Estado em prestar serviços jurídicos gratuitos a quem necessita, certo é que a corrente favorável à expressa permissão da atividade pro bono saiu vitoriosa, culminando na previsão legal disposta no Código de Ética e Disciplina promulgado em 2015.

Ressalte-se que outra solução não poderia haver para o embate, tendo em vista que a advocacia pro bono proporciona benesses tanto para o advogado que a pratica, quanto para a sociedade como um todo.

Assim, o instituto objeto dessa monografia revela-se um importante agente transformador da realidade social brasileira, de caráter suplementar aos Governos, os quais, devido a diversos fatores, não conseguem cumprir seu dever de construir uma sociedade justa e igualitária. 


\section{REFERÊNCIAS BIBLIOGRÁFICAS}

AGUIAR, Adriana. Advocacia gratuita é regulamentada pela OAB.

Disponível em: <http://www.ftiapr.org.br/noticias/noticias-juridicas/896advocacia-gratuita-e-regulamentada-pela-oab.html>. Acesso em: 05/06/2016.

APLICADA, Instituto de Pesquisa Econômica. Proporção de extremamente pobres (PO) - Linha de Pobreza Baseada em Necessidades Calóricas e Proporção de pobres (PO) - Linha de Pobreza Baseada em Necessidades Calóricas. Disponível em: <http://www.ipeadata.gov.br/>. Acesso em: 22/10/2016.

ARAÚJO, Thiago Cássio D’Ávila. Conceito $e$ características da advocacia. Disponível em: <https://jus.com.br/artigos/8324/conceito-ecaracteristicas-da-advocacia>. Acesso em: 30/10/2016.

BARROS, Nádia e Marcos Roberto Fuchs. Por que os advogados não podem atender de graça? Disponível em: <http://reporterbrasil.org.br/2013/12/por-que-os-advogados-brasileiros-naopodem-atender-de-graca/>. Acesso em: 22/07/2016.

BRITO, Lany Cristina Silva, Gabriella Vieira Oliveira Gonçalves, Ministério da Justiça, Secretaria de reforma do Judiciário (SRJ). Atlas de Acesso à Justiça: indicadores nacionais de acesso à justiça. Brasília: Ministério da Justiça, Secretaria de Reforma do Judiciário, 2015. Disponível em: <http://www.acessoajustica.gov.br/pub/_downloads/caderno_inaj_2015.pdf >. Acesso em: 08/10/2016. 
BONO, Instituto Pro. Convênio entre $O A B$ e Defensoria Pública não é caracterizado como advocacia pro bono e pode ser celebrado com qualquer entidade. Disponível em: <http://www.probono.org.br/convenioentre-oab-e-defensoria-publica-nao-e-caracterizado-como-advocacia-probono-e-pode-ser-celebrado-com-qualquer-entidade>. Acesso em: 09/06/2016.

BONO, Instituto Pro. Nota pública do Instituto Pro Bono sobre a suspensão das limitações à prática da advocacia pro bono no Brasil. Disponível em: <http://www.probono.org.br/nota-publica-do-instituto-probono-sobre-a-suspensao-das-limitacoes-a-pratica-da-advocacia-pro-bonono-brasil>. Acesso em: 10/10/2016.

BONO, Instituto Pro. Relatório Institucional 2012. Disponível em: <http://www.probono.org.br/arquivos/file/Relatorio2012.pdf>. Acesso em: 03/05/2016.

BOTELHO, Augusto de Arruda. Advocacia pro bono e o amplo acesso à justiça. Revista Jurídica Consulex, ano XVII, n. 398, 15 de ago de 2013. Pp. 26-27.

CAPPELlETTI, Mauro e BRYANT, Garth. Acesso à Justiça. Porto Alegre: Sergio Antonio Fabris Editor, 1988.

CANÁRIO, Pedro. Advogados se voltam contra Resolução Pro Bono da $O A B-S P$. Disponível em <http://www.conjur.com.br/2013-fev-23/grandesnomes-advocacia-voltam-resolucao-pro-bono-oab-sp>. Acesso em: 10/10/2016.>. Acesso em: 10/10/2016.

CANÁRIO, Pedro. Código de Ética da Advocacia liberará pro bono para pessoa física. Disponível em: <http://www.conjur.com.br/2015-jun- 
14/codigo-etica-advocacia-liberara-pro-bono-pessoa-fisica>. Acesso em: 04/07/2016.

CANÁRIO, Pedro. OAB-SP já se pronunciou 20 vezes contra pro bono. Disponível em: <http://www.conjur.com.br/2013-fev-26/oab-sppronunciou-20-vezes-advocacia-pro-bono>. Acesso em: 27/07/2016.

CASTRO, André Luís Machado de e Rafael Morais Português de Souza. Retrocesso $e$ Corporativismo. Disponível em: <http://www1.folha.uol.com.br/fsp/opiniao/61956-retrocesso-ecorporativismo.shtml>. Acesso em: 16/10/2016.

CAVAlCANTE, Andrey. Advocacia Pro Bono: A OAB em favor do cidadão.

Disponível

em:

$<$ http://www.portalrondonia.com/noticias/35957.htm>. Acesso em: 22/06/2016.

CORRÊA, Theresa Raquel Bethônico. Advocacia Pro Bono: Assistencialismo ou Compromisso Social? Disponível em: $<$ http://tpmagister.lex.com.br/lexnet/lexnet.dll/Dout/2bd?f=templates\&fn=d ocument-frame.htm\&2.0>. Acesso em: 21 de setembro de 2016.

COSTA, Marco Antônio Moreira da. O papel da advocacia solidária na ampliação do acesso à justiça. Disponível em: $<$ http://www.webartigos.com/artigos/o-papel-da-advocacia-solidaria-naampliacao-do-acesso-a-justica/98600/>. Acesso em: 13/09/2016.

D’URSO, Luiz Flávio Borges. Advocacia pro bono precisa de regras nacionais. Revista Jurídica Consulex, ano XVII, n. 398, 15 de ago de 2013. P. 35 . 
Declaração Pro Bono das Américas. Disponível em: http://www.dhnet.org.br/direitos/deconu/a_pdf/declaracao_probono_para_a s_americas.pdf.. Acesso em: 24/07/2016.

Defensoria Pública do Estado do Rio de Janeiro. Página: “O que é? Pra quem é?”. Disponível em: <http://www.defensoria.rj.def.br/Institucional/oque-e-defensoria>. Acesso em: 07/06/2016.

EXAME. Brasil cai para a posição de $9^{a}$ economia do mundo. Disponível em: <http://exame.abril.com.br/economia/pib-em-dolar-cai-25-e-brasil-caipara-a-posicao-de-9a-economia-do-mundo/>. Acesso em: 09/10/2016.

FARIA, José Eduardo. In: Formação jurídica. (coord.) José Renato Nalini. São Paulo: RT, 1999, p. 19

FUCHS, Marcos Roberto. Advocacia pro bono e o novo Código de Ética e Disciplina. Revista do Advogado da AASP, n. 129, abril de 2016. Pp. 7279.

FUCHS, Marcos Roberto e Flávia Piovesan. Advocacia de interesse público e o Instituto Pro Bono. Revista Jurídica Consulex, ano XVII, n. 398, 15 de ago de 2013. Pp. 40-42.

FUCHS, Marcos e Nádia Barros. Ideal da advocacia pro bono enfrenta obstáculos da OAB. Disponível em: <http://www.conjur.com.br/2013-nov20/ideal-advocacia-pro-bono-enfrenta-obstaculos-impostos-oab>. Acesso em: 22/07/2016.

GHIRELLO, Mariana. Corporativismo impede advogados de trabalhar sem cobrar. Disponível em: 
$<$ http://www.cartacapital.com.br/sociedade/corporativismo-impedeadvogados-de-trabalhar-sem-cobrar-3414.html>. Acesso em: 27/07/2016.

INVERNIZZI, Gabriela. Advocacia Pro Bono cresce e melhora imagem de escritórios. Disponível em: <http://www.conjur.com.br/2007-dez08/advocacia_pro_bono_cresce_melhora_imagem_escritorios>. Acesso em: 09/06/2016.

JAHAN, Selim. Relatório do desenvolvimento humano 2015. Disponível em: $\quad$ http://hdr.undp.org/sites/default/files/hdr15_overview_pt.pdf >. Acesso em: 09/10/2015.

JANEIRO, Poder Judiciário do Estado do Rio de. Juizado Especial Cível de Nova Friburgo tem inscrição para advogado dativo. Data da publicação: 27/01/2016. Disponível em: < http://www.tjrj.jus.br/web/guest/home//noticias/visualizar/29103?p_p_state=maximized $>$. Acesso em 07/10/2016.

JÚNIOR, Miguel Reale. Advocacia pro bono: ocupação feliz. Revista do Advogado da AASP, n. 129, abril de 2016. Pp. 105-109.

JÚNIOR, Miguel Reale. Responsabilidade Social. Disponível em: $<$ http://www.probono.org.br/advocacia-pro-bono/entenda>. Acesso em: 03/05/2016.

JURÍDICO, Consultor. Procuradoria pede que OAB-SP aprove pro bono. Disponível em: <http://www.conjur.com.br/2013-mar-18/procuradoriarepublica-aprovacao-advocacia-pro-bono-sao-paulo>. Acesso em: 09/06/2016.

JUSTIÇA, Secretaria de Reforma do Judiciário do Ministério da Justiça. Disponível em: <http://www.justica.gov.br/noticias/secretario-de-reforma- 
do-judiciario-defende-politica-nacional-de-acesso-a-justica-1>. Acesso em: 08/08/2016.

LAGOS, Marta e Lucía Dammert. La SeguridadCiudadana: El problema principal de América Latina. Ltinobarómetro, 09 de maio de 2012, p. 3.

MODÉ, Fernando Magalhães. A função social do advogado e a advocacia pro bono. Belo Horizonte: Revista de Direito do Terceiro Setor - RDTS. Ed.: ano 1, n. 1, jan/ jun. 2007. Disponível em: $<$ http://www.editoraforum.com.br/ef/wp-content/uploads/2016/08/funcaosocial-do-advogado.pdf.>. Acesso em: 04/08/2016.

NALINI, José Renato. O juiz e o acesso à justiça. São Paulo: RT, 2000.

MONTEIRO, Thiciane Araújo. Advocacia Pro Bono à luz da Ética. Disponível em: <http://hicidireito.jusbrasil.com.br/artigos/296276676/advocacia-pro-bonoa-luz-da-etica>. Acesso em: 04/07/2016.

NASCIMENTO, Gilberto. Advogados do Bem. Disponível em: <http://www2.uol.com.br/aprendiz/n_colunas/g_nascimento/ge081003.htm >. Acesso em: 08/10/2016.

NASCIMENTO, Marcos Henrique Caetano do. Advocacia pro bono e a democratização do acesso à justiça. Revista Jurídica Consulex, ano XVII, n. 398, 15 de ago de 2013. Pp. 36-37.

NAVES, Rubens e Guilherme Amorim Campos da Silva. Advocacia pro bono e advocacy. Revista Jurídica Consulex, ano XVII, n. 398, 15 de ago de 2013. Pp. 38-39. 
O’DONNEL, Guilhermo. Poliarquias e a (In)efetividade da Lei na América Latina. Novos Estudos, Cebrap, 51, 1998. Pp. 37-57.

OABRJ. Instituto Pro Bono elogia decisão da OAB. Disponível em: <http://www.oabrj.org.br/detalheConteudo/760/Instituto-Pro-Bono-elogiadecisao-da-OAB.html>. Acesso em: 08/06/2016.

$\mathrm{OAB}$, Conselho Federal da. OAB suspende a limitação de advocacia pro bono no país. Disponível em: <http://www.oab.org.br/noticia/25774/oabsuspende-a-limitacao-de-advocacia-pro-bono-no-pais>. Acesso em: 05/06/2016.

OLIVEIRA, Flávia Regina de Souza, et al. Advocacia Pro Bono: guia prático para escritórios. Disponível em: $<$ http://www.cesa.org.br/arquivos/com_advcom_cartilha.pdf $>$ Acesso: 23/07/2016.

OLIVEIRA, Flávia Regina de Souza e Juliana Gomes Ramalho Monteiro. Levando o pro bono a sério. Revista Jurídica Consulex, ano XVII, n. 398, 15 de ago de 2013. Pp. 28-29.

OLIVEIRA, Flávia Regina de Souza, et al. Advocacia Pro Bono: guia prático para escritórios. Disponível em: <http://www.cesa.org.br/arquivos/com_advcom_cartilha.pdf>. Acesso: 23/07/2016.

ORTEGA Y GASSET, José. La caza y los toros. 2. ed. Madrid: Revista do Ocidente, 1968. P. 30.

RIBEIRO, Paulo Afonso da Motta. O significado da advocacia pro bono. São Paulo: Revista Jurídica Consulex, ano XVII, n. 398, 15 de ago de 2013. P. 32-34. 
RÊGO, Humberto Henrique Costa Fernandes do e Victor dos Santos Maia Matos. Ética profissional e advocacia pro bono: o papel do advogado na conquista da cidadania. Revista do Advogado da AASP, n. 129, abril de 2016. Pp. 47-53.

RODAS, Sérgio. Pro bono é menos desenvolvido no Brasil do que no resto da América Latina. Disponível em: <http://www.conjur.com.br/2014-dez13/pro-bono-desenvolvido-brasil-america-latina\#top>. Acesso em: 13 de julho de 016 .

STRAUSS, Daniel et al. Advocacia de interesse público e voluntariado. Disponível em: <http://livro.educardpaschoal.org.br/upload/NossosLivros/61_livro_advoca cia.pdf>. Acesso em: 08/05/2016.

VIEIRA, Oscar Vilhena. A desigualdade e a subversão do Estado de Direito. Revista Internacional de Direito e Cidadania, n. 1, junho/2008. Pp. 185-201.

VIEIRA, Oscar Vilhena. Três teses equivocadas sobre "pro bono". Disponível em: <http://www1.folha.uol.com.br/fsp/opiniao/fz0903200610.htm >. Acesso em: 05/06/2016.

WERNECK VIANNA et al. A judicialização da política e das relações sociais no Brasil. Rio de Janeiro: Revan, 1999. 


\section{JURISPRUDÊNCIA}

STF, ADI 4163/SP, Rel. Ministro Cézar Peluso, Brasília, 29 de fevereiro de 2012.

STF, ADI 4163/SP, Rel. Ministro Cezar Peluso, Brasília, 29 de fevereiro de 2012.

STJ, Repercussão Geral No Recurso Extraordinário n. 607520 RG / MG, Min. Rel. Dias Toffoli, Tribunal Pleno, Brasília, Data de Julgamento: 09/09/2010

STJ, AgRg no AREsp 729318 / PE, Ministro Relator Sérgio Kukina, Primeira Turma, Brasília, Data do Julgamento: 17/05/2016

TJRJ, Apelação n. 0011378-55.2009.8.19.0026, Des. Rel. Norma Suely Fonseca Quintes, Oitava Câmara Cível, Rio de Janeiro, Data de Julgamento: 30/09/2013

TJRJ, Apelação n. 0190679-32.2012.8.19.0001,Des. Rel. Cristina Tereza Gaulia, Quinta Câmara Cível, Rio de Janeiro, Data de Julgamento: $27 / 10 / 2014$.

TJRJ, Apelação n.0000915-14.2012.8.19.0070, Des. Jacqueline Lima Montenegro, Décima Quinta Câmara Cível, Rio de Janeiro, Data De Julgamento: 28/06/2016.

Tribunal de Ética e Disciplina da OAB-SP, Proc. n. E-4.0852011, São Paulo, 15 de dezembro de 2011. 
Tribunal de Ética e Disciplina da OAB-SP, Proc. n. E-3.542/2007, São Paulo, 22 de novembro de 2007.

Tribunal de Ética e Disciplina da OAB-SP, Proc. n. E-2.392/0, São Paulo, 13 de dezembro de 2001. Ementa: Advocacia pro bono - Atividade voltada para o bem público, sem contrapartida financeira - Necessidade de regulamentação estabelecendo limites e coibindo abusos. 